\title{
Morphological and Functional Evidence of Sexual Dimorphism in the Retrochiasmatic Area Population of NK3R-containing Neurons in Sheep
}

Justin A. Lopez

West Virginia University, j.a.lopez@wingate.edu

Follow this and additional works at: https://researchrepository.wvu.edu/etd

Part of the Endocrinology Commons

\footnotetext{
Recommended Citation

Lopez, Justin A., "Morphological and Functional Evidence of Sexual Dimorphism in the Retrochiasmatic Area Population of NK3R-containing Neurons in Sheep" (2019). Graduate Theses, Dissertations, and Problem Reports. 3861.

https://researchrepository.wvu.edu/etd/3861

This Dissertation is protected by copyright and/or related rights. It has been brought to you by the The Research Repository @ WVU with permission from the rights-holder(s). You are free to use this Dissertation in any way that is permitted by the copyright and related rights legislation that applies to your use. For other uses you must obtain permission from the rights-holder(s) directly, unless additional rights are indicated by a Creative Commons license in the record and/ or on the work itself. This Dissertation has been accepted for inclusion in WVU Graduate Theses, Dissertations, and Problem Reports collection by an authorized administrator of The Research Repository @ WVU. For more information, please contact researchrepository@mail.wvu.edu.
} 
Morphological and Functional Evidence of Sexual Dimorphism in the Retrochiasmatic Area Population of NK3R-containing Neurons in Sheep

Dissertation submitted to the Davis College of Agriculture, Natural Resources and Design at West Virginia University in partial fulfillment of the requirements for the degree of

Doctor of Philosophy

in

Reproductive Physiology

Justin A. Lopez

Robert L. Goodman, PhD; Mentor

Stanley M. Hileman, PhD

Michael W. Vernon, PhD

Steven L. Hardy, PhD

Robert A. Dailey, PhD

Reproductive Physiology

Morgantown, West Virginia

2019

Keywords: gonadotropin releasing hormone, luteinizing hormone, kisspeptin, NK3R, NKB, galanin, sexual differentiation, sheep

Copyright 2019 Justin Angelo Lopez 


\section{ABSTRACT \\ Morphological and Functional Evidence of Sexual Dimorphism in the Retrochiasmatic Area Population of NK3R-containing Neurons in Sheep}

The neuropeptides neurokinin B (NKB) and kisspeptin are critical for fertility in humans and potent stimulators of gonadotropin-releasing hormone $(\mathrm{GnRH})$ and luteinizing hormone (LH) secretion in primates and sheep. We previously demonstrated that administration of a selective $\mathrm{NKB}$ receptor (NK3R) agonist, senktide, within the retrochiasmatic area $(\mathrm{RCh})$ resulted in surgelike release of LH and increased cellular expression of kisspeptin neurons in the arcuate nucleus (ARC) of female lambs. Based on these findings, we concluded that NKB-responsive neurons in the RCh act to stimulate GnRH secretion by inducing kisspeptin release from neurons in the ARC.

One important characteristic of the LH surge in many species is that it is sexually dimorphic, occurring in females but not in males. As such, we tested if the response to local administration of senktide is sexually dimorphic and examined sex differences in NKB and NK3R expression in ewe-lambs and wethers (rams that were castrated three weeks after birth). In females, senktidecontaining microimplants placed in the RCh produced a significant increase in LH concentrations that lasted for at least 8 hours after the start of treatment, while a much shorter increase ( $\sim 2$ hours) was seen in males. Based on previous work, as expected, there were more NKB-containing neurons in the ARC of females than males. Interestingly, there was a similar sexual dimorphism in numbers of NK3R-containing neurons in the RCh and preoptic area (POA), NKB-containing close contacts onto these RCh NK3R neurons, and NKB-positive fibers in this region. These data demonstrate that there are both functional and morphological sex differences in NKB-NK3R signaling in the 
$\mathrm{RCh}$ and raise the possibility that this dimorphism contributes to the sex-dependent ability of estradiol to induce an LH surge in female sheep.

To determine if a neuroanatomical basis exists for this sexual dimorphism in acutelygonadectomized animals, we characterized the expression of NK3R-, NKB-, and kisspeptincontaining neurons in the hypothalamus. In the ARC, the total number of NKB or kisspeptin neurons was higher in females than males, but no difference was observed in the percentage of NKB or kisspeptin cells that colocalized with NK3R. There was no difference in numbers of NK3R-containing neurons in the POA between females and males, however, a significantly greater number of NK3R-ir cells was observed for females in the RCh. These data provide evidence for a sexual dimorphism in the neurological control of the LH surge and further indicate that the sexual dimorphism in ARC kisspeptin neurons is due to the organizational actions of gonadal steroids.

The true phenotype of NK3R-containing neurons in the RCh has yet to be elucidated. However, one potential neurotransmitter coexpressed in these neurons is galanin. In a preliminary study in sheep, it was discovered that $20-30 \%$ of NK3R-positive neurons contain galanin. Galanin stimulates LH secretion in several species and its expression has been shown to be sexually dimorphic in rodents. We investigated the distribution of galanin/NK3R neurons in the $\mathrm{RCh}$ to determine if this population is sexually dimorphic in sheep. Furthermore, we assessed the effect of central galanin administration on tonic LH secretion and galantide (a non-specific galanin receptor antagonist) infusion during the breeding season and in anestrous ewes to determine the influence of blocking galanin input on both tonic and surge LH secretion in this species. The number of NK3R-ir cells in the RCh was greater in females than in males. However, no difference was 
observed in the number of galanin-immunoreactive cells found within the RCh. Furthermore, no significant difference was observed in the percentage of galanin/NK3R co-expression between sexes. In the assessment of galanin effects on LH secretion, a minor stimulatory effect of galanin was observed on LH pulse frequency $(\mathrm{P}=0.07)$ during anestrous and on LH pulse amplitude during the breeding season ( 5 nmole dose; $\mathrm{P}=0.06$ ). During an estrogen-induced surge, galantide infusion resulted in a minor, not significant, inhibitory effect on surge amplitude (approximately by $25 \%$ ) in animals during the breeding season. These results tentatively support a neuroanatomical framework for galanin activity and provide preliminary evidence that endogenous galanin may contribute to LH secretion in sheep, however, more pharmacological work is needed to rigorously test this hypothesis. 


\section{ACKNOWLEDGEMENTS}

I have many people to thank for my success West Virginia University. First I would like to thank my family, particularly my parents, brothers, and nonna, for the support and encouragement in moving to "wild and wonderful" West Virginia to pursue a career in research. I am also lucky to an incredibly supportive extended family and many exceptional role models in my life.

I would like to thank Robert Goodman and Stanley Hileman for their continuous support and advice throughout my graduate career, as well as through the process of completing this dissertation. Their combined input and experience has provided a valuable learning environment that is enjoyable and intellectually stimulating. Many other faculty members have been instrumental, including Steve Hardy, Mike Vernon, and Robert Dailey. Each has generously shared their experiences and knowledge. I thank them for their willingness to serve on my committee and ability to always challenge my perception of basic science research and reproductive neuroendocrinology. 


\section{LIST OF NOMENCLATURE}

AHA Anterior hypothalamic Area

AMH Anti-Mullerian hormone

ARC Arcuate Nucleus

CIDR Controlled internal release device

CL Corpus luteum

DBB Diagonal Band of Broca

DHT Dihydrotestosterone

Dyn Dynorphin

E2 Estradiol

$\mathbf{E R} \boldsymbol{\alpha}$ Estrogen Receptor-alpha

FSH Follicle Stimulating Hormone

GnRH Gonadotropin- Releasing Hormone

ICV intracerebroventricular

IgG Immunoglobulin G

IHC Immunohistochemistry

KNDy Kisspeptin, Neurokinin B,

Dynorphin

LH Luteinizing Hormone
LHA Lateral hypothalamic area

MBH Mediobasal hypothalamus

ME Median eminence

NK3R Neurokinin 3 Receptor

NKB Neurokinin B

OCh Optic chiasm

OVX Ovariectomized

P4 Progesterone

PB Phosphate Buffer

PBS Phosphate Buffered Saline

PBST Phosphate Buffered Saline with

Triton X-100

PGF2 $\alpha$ Prostaglandin F2 $\alpha$

POA Preoptic area

PR Progesterone Receptor

RCh Retrochiasmatic area

SRY Sex-determining region Y

VMN Ventral Medial Nucleus 


\section{LIST OF FIGURES}

Figure 1.1. Schematic illustration of hormone secretory profiles across the follicular phase in the ew.

Figure 1.2. Model for control of KNDy neural activity proposed to drive episodic GnRH secretion

Figure 1.3. Schematic representation of connectivity between neurons implicated in the luteinizing hormone surge in sheep

Figure 1.4. Timing of puberty in spring-born male and female lambs, and corresponding changes in $\mathrm{LH}$ secretion, in relation to age and photoperiod

Figure 1.5. Effects of androgen treatment in utero on external genitalia, neuroendocrine sexual maturation, and the LH surge in female lambs

Figure 2.1. Effect of senktide-containing microimplants on LH secretion during an artificial follicular phase in female and male sheep

Figure 2.2. Mean LH concentrations after administration of senktide-containing microimplants within the RCh

Figure 2.3. NK3R immunoreactivity in the POA during an estrogen-induced LH surge in female and male sheep

Figure 2.4. NK3R immunoreactivity in the RCh during an estrogen-induced LH surge in female and male sheep

Figure 2.5. NKB immunoreactivity in the ARC during an estrogen-induced LH surge in female and male sheep

Figure 2.6. NKB and NK3R immunoreactivity in the RCh during an estrogen-induced LH surge in female and male sheep

Supplemental Figure 2.1. Steroid-induced suppression of LH secretion in wethers

Figure 3.1. Representative LH concentrations over time for a female sheep compared to that of a male sheep after the administration of estrogen implants

Figure 3.2. Mean LH concentrations for acutely-castrated female and male sheep during exposure to low levels of estrogen and progesterone, only low levels of estrogen, or surge-inducing levels of estrogen 
Figure 3.3. NK3R immunoreactivity in the POA and RCh during an estrogen-induced LH surge in acutely-castrated female and male sheep

Figure 3.4. NKB, kisspeptin, and NK3R immunoreactivity in the ARC during an estrogen-induced LH surge in acutely-castrated female and male sheep

Figure 3.5. NKB and NK3R immunoreactivity in the RCh during an estrogen-induced LH surge in acutely-castrated female and male sheep

Figure 4.1. Galanin and NK3R immunoreactivity in the RCh during an estrogen-induced LH surge in female and male sheep

Figure 4.2. Galanin and CT $\beta$ immunoreactivity in the $\mathrm{RCh}$ of female sheep

Figure 4.3. Effect of icv injection of galanin on LH secretion in ovary-intact anestrous ewes

Figure 4.4. Effect of icv injection of galanin on LH secretion in ovary- intact breeding season ewes

Figure 4.5. Effect of galantide on the estrogen-induced LH surge during the breeding season 


\section{TABLE OF CONTENTS}

$\begin{array}{ll}\text { ABSTRACT } & \text { ii }\end{array}$

ACKNOWLEDGEMENTS $\quad \mathrm{v}$

LIST OF NOMENCLATURE

LIST OF FIGURES $\quad$ vii

CHAPTER I: REVIEW OF LITERATURE 1

1. Reproductive Axis 2

2. Reproductive Cycles 2

3. Patterns of GnRH, LH, and FSH Secretion $\quad 5$

1. Tonic secretion of GnRH and $\mathrm{LH} \quad 6$

2. $\quad$ Surge secretion of $\mathrm{GnRH}$ and $\mathrm{LH} \quad 7$

3. FSH secretion 18

4. Ovarian Development and Function 10

5. Neuroendocrine Control of Reproductive Function 14

1. Neuroanatomy 14

2. Kisspeptin/Kiss1R 16

3. Neurokinin B/NK3R 17

4. Galanin 18

5. The GnRH pulse generator 20

6. KNDy Neurons and Steroid Feedback 23

7. The GnRH/LH surge 24

6. Mechanisms for Sexual Differentiation of Reproductive Function 32

7. Objectives 42

8. References 45

CHAPTER II: Morphological and functional evidence for sexual dimorphism in the retrochiasmatic area population of NK3R-containing neurons

$\begin{array}{ll}\text { Abstract } & 63\end{array}$

Introduction $\quad 64$

Materials and Methods $\quad 66$

$\begin{array}{ll}\text { Results } & 75\end{array}$

$\begin{array}{ll}\text { Discussion } & 77\end{array}$

References $\quad 84$

Figure Legend $\quad 88$

$\begin{array}{ll}\text { Figures } & 91\end{array}$

CHAPTER III: Morphological Implications of Sexual Dimorphism in the Expression of Hypothalamic Kisspeptin and NK3R Neurons 
$\begin{array}{lc}\text { Abstract } & 90 \\ \text { Introduction } & 92 \\ \text { Materials and Methods } & 104 \\ \text { Results } & 111 \\ \text { Discussion } & 113 \\ \text { References } & 120 \\ \text { Figure Legend } & 123 \\ \text { Figures } & 125\end{array}$

CHAPTER IV: The role of retrochiasmatic area galanin neurons in mediating the effects of NKB during the LH surge

Abstract

132

Introduction

133

Materials and Methods

136

Results

Discussion

References

153

Figure Legend

Figures

CHAPTER V: General discussion 164

1. NKB-NK3R Activity and the LH Surge

165

2. NKB-NK3R Expression in the POA and RCh of Male and Female sheep

3. NKB, Kisspeptin, and NK3R Expression in the ARC of Male and Female Sheep

4. Galanin Expression in the RCh of Sheep 170

5. Galanin Activity and LH Secretion

171

6. Conclusions and Future Directions

172

7. References

175

CURRICULUM VITAE 
Morphological and Functional Evidence of Sexual Dimorphism in the Retrochiasmatic Area Population of NK3R-containing Neurons in Sheep

CHAPTER 1

REVIEW OF LITERAURE 


\section{The Reproductive Axis}

Appropriate control of reproductive function requires communication from the brain, the pituitary gland, and the gonads. The brain controls the hypothalamic-pituitary-gonadal (HPG) axis via the release of the hypothalamic decapeptide gonadotropin-releasing hormone $(\mathrm{GnRH})$ from neurons spread throughout the preoptic area (POA) and mediobasal hypothalamus (MBH). GnRHcontaining neurons send axonal projections to the median eminence (ME) where, after release, GnRH travels through the hypophyseal portal system of blood vessels that connects the ME with the anterior pituitary and gonadotropic cells that exist therein. Upon stimulation, gonadotropic cells are capable of releasing both luteinizing hormone (LH) and follicle-stimulating hormone (FSH). Gonadotropin release from the anterior pituitary is critical for appropriate reproductive function and fertility in both males and females. These hormones are essential for processes related to gametogenesis (spermatogenesis in males and oogenesis in females) and steroidogenesis (synthesis and release of gonadal steroid hormones testosterone in males, progesterone in females, and estrogen in males and females, respectively). In females, steroid hormone release from the gonads participates in the active control of neuroendocrine reproductive function by way of feedback loops that modulate GnRH and LH/FSH secretion throughout the course of an estrous cycle or menstrual cycle (primates).

\section{Reproductive Cycles}

After puberty, females enter a period of life-long reproductive cyclicity - albeit with interruptions such as pregnancy, nursing, menopause (primates), and season in some species - that allows for 
multiple opportunities to copulate, become pregnant, and rear offspring. Generally speaking, females can be characterized to exhibit one of three types of estrous cyclicity: polyestrus, seasonally polyestrus, and monoestrus. Polyestrous females, such as cattle, swine, some species of rodents, and primates display consistent and uniform reproductive cycles that occur throughout the entire year. These females can become pregnant at any time without regard to season. Similarly, seasonally polyestrus females, such as sheep, goats, certain rodents species such as hamsters, and mares, display consistent and uniform series of reproductive cycles that occur within a specific season of the year; short-day breeding females (sheep and goats) begin to cycle during shortening days of the fall, while long-day breeding females (hamsters and mares) begin to cycle during lengthening days of the summer. This type of reproductive cycle combines with the respective lengths of gestation to permit birth of young at a time of the year that is optimal for survival. Lastly, and in contrast to polyestrus females, monoestrus females, such as dogs, are characterized as having only one estrous cycle per year. In contrast to females, male reproduction (i.e. sperm production) in most mammals, remains generally consistent throughout the year due to adequate secretion of GnRH from the hypothalamus, FSH and LH from the anterior pituitary, and steroids (estradiol and testosterone) from the testes to support fertility.

The estrous/menstrual cycle consists of two major phases named after the dominant structure on the ovary during each phase of the cycle. The follicular phase is the period of time between corpora lutea regression and ovulation. In most species, the follicular phase is relatively short, covering approximately $20 \%$ of the entire estrous cycle. The dominant ovarian structures at this time are large, growing antral follicles that are preparing for ovulation and secreting the steroid hormone estradiol. During the follicular phase, four significant events take place within the HPG axis: LH 
and FSH release from the anterior pituitary, follicular preparation for ovulation, sexual receptivity (estrus), and ovulation. During the early follicular phase, GnRH pulse frequency increases due to low levels of circulating progesterone, causing the release of both LH and FSH from the anterior pituitary. Once released into the systemic circulation, these gonadotropins stimulate follicular development and the release of low levels of estradiol from growing follicles, which continues until this steroid reaches a level high enough to stimulate surge secretion of GnRH from the hypothalamus, and subsequently LH from the anterior pituitary and estrous behavior. The increasingly high level of estradiol that results in estrous behavior and surge secretion of GnRH and LH is then shortly followed by the first meiotic division of the oocyte and ovulation. After ovulation, the theca interna and granulosa cells of the follicle undergo luteinization; a process governed by LH. The functional corpus luteum (CL) consists of large luteal cells derived from granulosa cells and small luteal cells derived from thecal cells. The CL becomes the dominant ovarian structure during the luteal phase and secretes the steroid hormone progesterone. Increasing levels of progesterone will begin to inhibit GnRH pulse frequency, prevent behavioral estrus, and thwart any further LH surges. Thus, the luteal phase is the period of time from ovulation and formation of the CL to corpora lutea regression. In many species, the luteal phase is much longer than the follicular, lasting approximately $80 \%$ of the entire estrous cycle. If pregnancy does not occur, luteolysis ensues, resulting in cessation of progesterone secretion, structural regression of the $\mathrm{CL}$, and removal of progesterone negative feedback on GnRH secretion, ushering in a new follicular phase. In sheep, a 16- to 17-day estrous cycle will have a 2- to 3-day follicular phase and a 13- to 14-day luteal phase. The delineation between a follicular phase and subsequent luteal phase is ovulation. 


\section{Patterns of GnRH, LH, and FSH Secretion}

The intimate relationship of GnRH and LH secretion - i.e., changes in LH release patterns reflect changes in GnRH release patterns - allows for $\mathrm{LH}$ secretion to act as a reliable and easily measurable index of GnRH secretion. Considerable progress has been made into understanding the dynamic release patterns of GnRH, and subsequently $\mathrm{LH}$, due to the size and accessibility of the portal microcirculation in sheep (1). Moreover, FSH, working in conjunction with $\mathrm{LH}$, serves a particular role in promoting folliculogenesis.

Two modes of secretion of GnRH exist: tonic and surge secretion. Tonic GnRH secretion is episodic and drives low level LH pulses throughout the estrous cycle that are important for steroidogenesis. A robust and prolonged elevation of GnRH (surge GnRH secretion), triggered by high levels of circulating estrogen late in the follicular phase, is closely followed by a surge of LH. The control of pulsatile or surge-like GnRH secretion occurs via negative or positive estrogen feedback, respectively, acting at different neuroanatomical sites throughout the POA and MBH. Regulation of tonic GnRH secretion by estrogen negative feedback has been identified as occurring in the MBH in sheep (2), rats (3), and primates (4). In contrast, control of surge GnRH secretion by estrogen positive feedback has been identified as occurring in the MBH in sheep (2) and primates (5), and the anteroventral periventricular region (AVPV) and adjacent areas in rodents

(6-8). Because GnRH neurons do not contain the steroid receptors that mediate the actions of 
estrogen (9), progesterone (10), or androgen (11), an indirect route for steroid feedback is likely utilized. Some of these intermediates will be discussed in detail in later sections.

\section{Tonic Secretion of GnRH and LH}

Adequate pulsatile secretion of GnRH is essential for normal reproductive function (12). Throughout the estrous cycle in females, and over the course of a lifespan in males, LH is regularly secreted from the anterior pituitary in a pulsatile manner in response to pulsatile $\mathrm{GnRH}$ secretion from the hypothalamus (13). The intermittent release pattern of GnRH comprising each pulse is driven by a coordinated network of cells located in the hypothalamus, termed the GnRH pulse generator (14).

In male sheep, testicular testosterone acts to regulate GnRH and LH pulse frequency and amplitude with no consistent changes in pulse patterns over the course of a lifetime (15). In females, however, the frequency and amplitude of GnRH and LH pulses vary over the course of an estrous cycle due to feedback regulation by ovarian steroids (13). During the breeding season, estrogen and progesterone act to suppress GnRH pulse amplitude and frequency, respectively, and these actions are mediated by ER $\alpha$ and PR-dependent mechanisms via signaling in the hypothalamus in females (16). During the mid-luteal phase, when progesterone levels are high, GnRH and LH pulse frequency is low, while pulse amplitude is high. After luteolysis - regression of the CL and rapid decline in progesterone levels - GnRH and LH pulse frequency increases, while pulse amplitude begins to decrease (17). Generally speaking, pulse frequency is high during the follicular phase of 
the estrous cycle, decreases to a nadir during the luteal phase, and then progressively increases throughout the next follicular phase. Because changes in LH pulse amplitude are not as drastic as changes in LH pulse frequency, mean concentrations of LH correlate better with the prevailing state of pulse frequency in female sheep (17).

\section{Surge Secretion of GnRH and $\mathrm{LH}$}

The second mode of GnRH and LH secretion occurs toward the end of the follicular phase in response to estrogen positive feedback from the ovary and results in a transient, massive discharge of LH from the anterior pituitary $(18,19)$; an event that causes ovulation - the release of a mature egg from the ovary - and correlates with a well-defined period of sexual receptivity (estrous behavior) in most species. During a surge, GnRH concentrations are 20- to 40- fold higher than that of basal GnRH levels, while LH concentrations rise to levels that are nearly 100 times that of basal LH concentration. In sheep, the LH surge lasts approximately 12 hours, with the length of time from surge onset to ovulation ranging from $22-26$ hours $(17,18)$. One important characteristic of the LH surge in many species, including rodents (20), sheep (21), and humans (22), is that it is sexually dimorphic. In sheep, exogenous estrogen treatment, whether alone or preceded by progestin treatment, stimulates surge-like secretion of LH in ovariectomized ewes, but not in castrated male- or female-oriented rams (23).

\section{FSH Secretion}


During the early follicular phase, there is a transient rise in FSH secretion that occurs prior to a nadir the day before the preovulatory LH surge. After this nadir, there is a surge in FSH secretion that is coincident with the surge of GnRH and LH release prior to ovulation, though of less magnitude than that of LH (likely due to inhibin release from the ovary, which will be discussed later in this chapter) (24). FSH secretion throughout the rest of the cycle is controlled by the negative feedback effects of both estradiol and inhibin (both derived from antral follicles). At this stage of the cycle, modest, transitory elevations in inhibin are thought to control the overall level of negative feedback. In contrast, estradiol is responsible for the day-to-day fluctuations in the concentration of FSH (25). Another peak and nadir in FSH follows approximately 24 and 42 hours after the first peak and nadir, respectively. During the luteal phase, small increases in the FSH concentration normally occur proceeding new waves of follicular development (discussed in later section). 
Figure 1.1. Schematic Illustration of hormone secretory profiles cross the follicular phase in the ewe

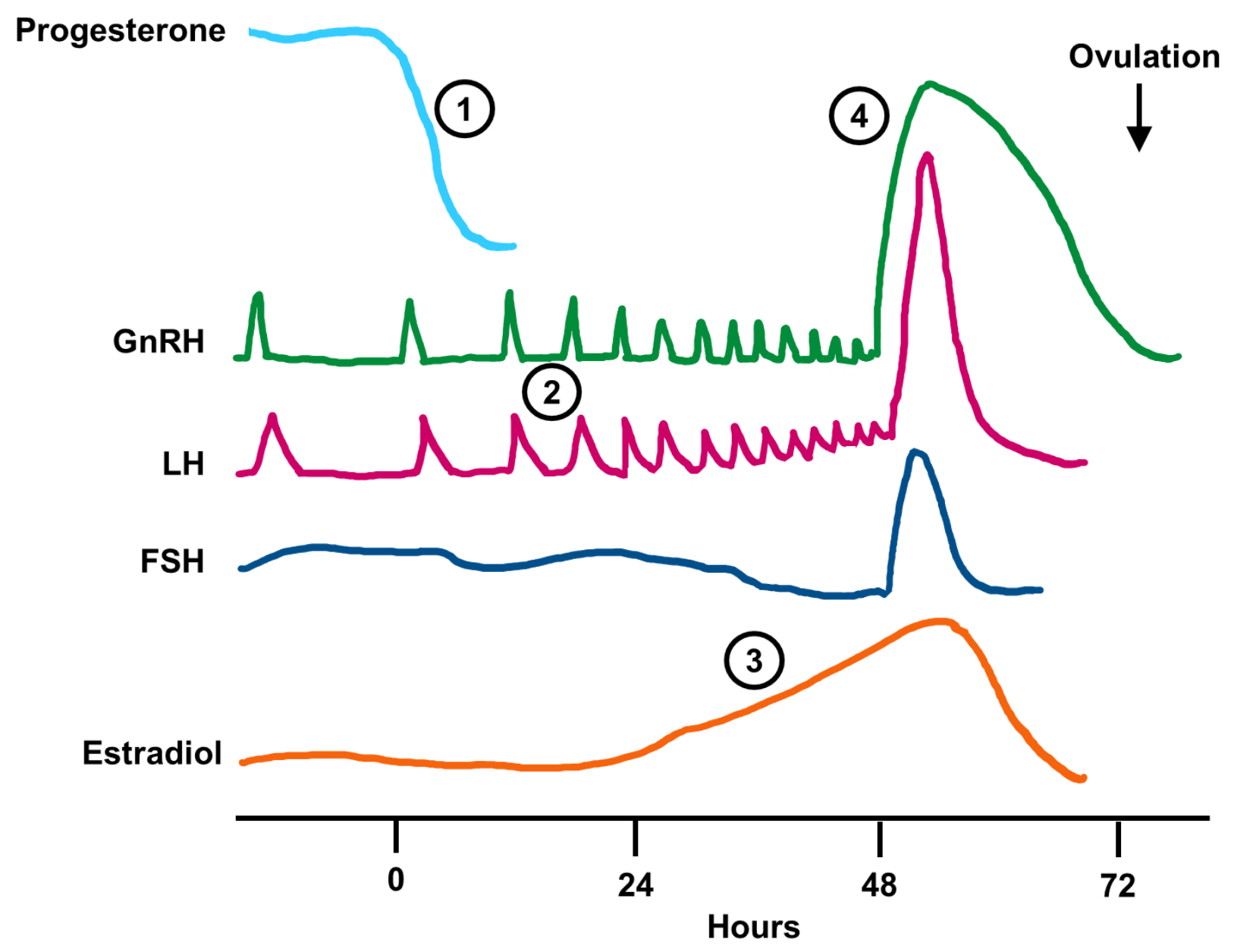

Figure 1. Schematic illustrating hormone secretory profiles across the follicular phase in the ewe. Circulating progesterone (blue) rapidly declines after luteolysis (1) followed by an increase in GnRH (green) and LH (pink) pulse frequency concomitant with a decrease in amplitude (2). Rising estradiol (orange) levels (3) give rise to the GnRH and LH surges (4) which trigger ovulation. Prog, progesterone; GnRH, gonadotropin-releasing hormone; LH, luteinizing hormone; FSH, follicle-stimulating hormone (navy). Modified from Senger et al., 2003 (26). 


\section{Ovarian Development and Function}

The process leading up to the formation of primordial follicles takes place during early fetal life, occurring shortly after sexual differentiation, or approximately day 35 of gestation, in sheep (27). Initially, mitotically active oogonia in the cortical region of the developing ovary interact with adjacent mesonephric cells to form the ovigerous cords. After oogonia become isolated from the interstitium, they begin to recruit and eventually form tight junctions with somatic pre-granulosa cells from the surface epithelium. Once attached, oogonia proliferate and/or enter meiosis (28). Concurrent with some germ cells proliferating or initiating meiosis, there are others that are undergoing apoptosis (approximately 80\% of germ cells). Often, germ cells in the early stages of meiosis are adjacent to germ cells undergoing apoptosis. The formation of primordial follicles in the fetal ovary begins around gestation day 75 in sheep and day 90 in cattle (28). Each primordial follicle consists of an oocyte surrounded by a single layer of granulosa cells (range of granulosa cells: 3 to 52)(29). More than $75 \%$ of these growing follicles undergo atresia by gestation day 90 in sheep, leaving young sheep with approximately 40,000 to 300,000 primordial follicles (high level of individual variability). Once follicles emerge from the primordial follicle pool they are committed to gonadotropin-independent growth. Drastic increases in size are observed as

primordial follicles transition to the primary stage; the oocyte enlarges due to 3 - to 10 -fold increases in the volume of the smooth endoplasmic reticulum, mitochondria, ribosomes, and lipid droplets, and the granulosa cells increase in number (range 30 to 520) and become cuboidal in shape (29). 
Even though the follicular phase comprises only $20 \%$ of the estrous cycle, follicular growth and atresia occurs during the entire estrous cycle in response to fluctuations in circulating levels of FSH and LH. As such, antral follicles are normally always present on the ovary. However, it is important to recognize that the majority of "follicle life" is spent in preantral stages. Generally speaking, follicles can be placed into 5 main categories based on the respective stage of development during folliculogenesis (27): primordial, committed, gonadotropin-responsive, gonadotropin-dependent, and ovulatory. (1) Primordial follicles are the largest population of follicles present. The oocyte and granulosa cells of these follicles contain receptors for certain growth factors, but not for LH or FSH. After emerging from the primordial pool, follicles enter a process of growth and development that ends in either atresia or ovulation. (2) Committed follicles, or primary and small preantral follicles, are not yet sensitive to FSH and LH secretion, but do undergo continual growth with a low rate of atresia. Additionally, during the committed stage, the zona pellucida begins to develop. (3) Gonadotropin-responsive follicles (range from large preantral to small-medium antral in size) develop a LH-responsive theca interna and FSHresponsive granulosal cell layer, while the phenotypic profile of the cumulus cells differentiates in response to oocyte-mediated signals. During this stage, there is also an increase in the number of follicles that undergo atresia coupled with an increased requirement for gonadotropins. (4) Medium-large antral gonadotropin-dependent follicles are highly susceptible to changes in concentrations of circulating FSH and LH. If FSH concentrations are low prior to the development of LH receptors in granulosa cells, these follicles will become atretic. Additionally, there is a high rate of atresia that is associated with the development and emergence of ovulatory follicles. (5) Ovulatory follicles are unique in that they can survive low levels of circulating FSH because the 
granulosa cells express LH receptors. As the name suggests, these follicles rupture in response to surge-levels of LH; i.e., ovulation.

Cows are single-ovulators that have 2 to 3 well-characterized FSH-induced waves of recruitment, selection, dominance, and atresia of antral follicles over a 21-day cycle. In contrast, ewes may experience many waves (ranging 2 to 6 ) that sometimes overlap (30), each spanning 4 to 8 days during a 17-day cycle (31), and often potentially produce more than one ovulatory follicle (32). A wave begins when small quantities of FSH are released from the anterior pituitary in response to a lessening of negative feedback (estradiol and inhibin) as a result of ovulation of a dominant follicle or atresia of potentially dominant follicles. This rise in FSH produces the growth and development of a cohort of small gonadotropin-dependent antral follicles that emerge from a pool of gonadotropin-responsive follicles $(33,34)$. These emerging follicles grow to ovulatory size (5 to $8 \mathrm{~mm}$ in the ewe, 15 to $18 \mathrm{~mm}$ in the cow) and develop granulosa cell-bound LH receptors, gaining the ability to switch dependence from FSH to LH. They also start to produce large quantities of estradiol and inhibin A, which in turn, act in conjunction to suppress FSH release from gonadotropes of the anterior pituitary gland. The deprivation of FSH release limits the growth of other gonadotropin-dependent follicles and eventually leads to atresia in these follicles (35). The remaining potentially ovulatory follicles that have achieved LH dependence may ovulate shortly after atresia of the previous ovulatory follicle if an LH surge occurs, or stop producing estradiol and become atretic within approximately 72 hours if a LH surge does not occur, thus initiating the next wave (36). 
Follicular rupture, or ovulation, is initiated by an increase in 3'5'-cyclic adenosine monophosphate (cAMP) in theca and granulosa cells that is induced by the LH surge and ultimately acts to block the synthesis of estradiol from progesterone. Rupture of the oocyte is accomplished by follicular hyperemia and proteolytic activity, coupled with contractions of smooth muscle cell-types in the follicular wall (37). The preovulatory rise in LH secretion also stimulates the release of urokinasetype plasminogen activator (uPA) from the ovarian surface epithelium, which aids in the conversion of interstitial plasminogen to plasmin. The resulting structural degradation of the apical wall via activation of collagenases and collagenolysis is potentiated by increases in transcription of matrix metalloproteinases (MMPs) in response to TNF $\alpha$ release from the thecal endothelium $(38,39)$. Following ovulation, the steroidogenic cells of the CL are formed by transformation of granulosa cells into large luteal cells and thecal cells into small luteal cells (40). Development of the $\mathrm{CL}$ is associated with angiogenesis and marked changes in cellular function. Within luteal tissue, large cells are thought to secrete most of the total progesterone released from the CL and are unresponsive to LH. One explanation for this finding is that these cells contain 6-fold more steroidogenic acute regulatory protein (StAR) and 2.4-fold more endozepine - two proteins critical for the production of progesterone - than small luteal cells (40). Alternatively, small luteal cells secrete progesterone via LH-mediated stimulation of StAR (41). Evidence also shows that growth hormone acts in conjunction with LH to provide supplemental luteotropic support in ruminants (42).

The structural demise of the CL, which is preceded by a loss of steroidogenic function, is referred to as luteolysis. This structural regression is induced by the uterine-derived luteolytic factor, prostaglandin F2 $\alpha$ (PGF2 $\alpha$ ), in sheep. PGF2 $\alpha$ enters the ovarian artery from the utero-ovarian vein 
via a countercurrent exchange mechanism that allows for local delivery of this prostaglandin (43). There are multiple pathways by which PGF2 $\alpha$ may exert its effects; these major processes include luteal secretion of oxytocin (44), rapid reduction in luteal blood flow (45) and progesterone synthesis (46), and induction of apoptotic mechanisms and structural luteolysis (47). These processes ultimately lead to the functional (termination in progesterone synthesis) and structural (degradation of luteal tissue) demise of the CL.

\section{Neuroendocrine Control of Reproductive Function}

\section{Neuroanatomy}

The relatively small GnRH neuron population (1,000 to 2,000 neurons) is found dispersed throughout the diencephalon, but predominantly existing in the POA (50\%) for most mammalian species. The remaining neurons are scattered throughout the Diagonal Band of Broca (dBB), anterior hypothalamic area (AHA), and the mediobasal hypothalamus (MBH), which encompasses the arcuate nucleus (ARC), dorsomedial nucleus (DMH), and ventromedial nucleus (VMN) (48). GnRH cells are multipolar, have extensive dendritic processes, and the majority extend one or more fibers to the median eminence (ME). These GnRH neuronal processes extend to the external zone of the ME where the GnRH peptide can be released into the portal vasculature at the stalk median eminence that functionally connects this area to the anterior pituitary gland.

As previously mentioned, GnRH neurons are devoid of both ER $\alpha$ and PR, signifying that the effects of these steroids are likely mediated through neuronal intermediates. Over the course of the 
last half-century, a plethora of intermediates containing steroid receptors have been implicated in the control of GnRH release in ewes. These include classical neurotransmitters such as dopamine (49,50), gamma-aminobutyric acid (GABA) (51), glutamate (52), and norepinephrine (NE) $(53,54)$ in A1 noradrenergic cells, more recently-discovered neuropeptides such as kisspeptin (55), galanin (56), orphanin-FQ (OFQ) (57), and RF-amide related peptide 3 (RFRP3) (58), and other known neuropeptides such as dynorphin (59), neurokinin B (NKB) (60), $\beta$-endorphin (49), neuropeptide Y (NPY) (50), and somatostatin (SST) (61). Within the last decade, particular interest has grown in a population of neurons that exist within the ARC that co-express kisspeptin, NKB, and dynorphin (thus given the name KNDy neurons)(62). In sheep, afferents from KNDy neurons project to the POA where $40 \%$ of GnRH cell bodies are found to be contacted by KNDy inputs (63). Additionally, 95\% of ARC KNDy neurons co-express ER $\alpha(64,65)$ and recently, KNDy neurons have been shown to project to $60 \%$ of MBH GnRH neurons (66). These lines of evidence make KNDy neurons likely candidates in mediating estrogenic effects on GnRH neurons in sheep. Based on genetic mutations and functional evidence from pharmacological studies using receptor agonists and/or antagonists, the effects of kisspeptin $(67,68)$ and NKB $(69,70)$ are generally accepted as being stimulatory, while the effect of dynorphin $(71,72)$ is inhibitory, to GnRH. Another potential candidate, which is the focus of some of the work in this dissertation, is galanin. This neurotransmitter is co-localized in a subpopulation of GnRH neurons and its expression is stimulated by estradiol (56). Galanin-immunoreactive neurons are distributed throughout the diencephalon, including areas of the hypothalamus - the PVN, AHA, and ARC - and have been shown to express ER $\alpha$ (73). Although galanin can act via receptors Gal-R1, Gal-R2, and Gal-R3 (mRNA for all three is found in the POA, PVN, and ARC), only Gal-R1 protein is found in ovine 
GnRH neurons $(74,75)$. Neither the effects of galanin, nor its receptor agonists and antagonists, have been reported in ewes and remain to be investigated.

\section{Kisspeptin/Kiss1r}

The discovery of kisspeptin has led to significant developments in the understanding of the neural mechanisms controlling reproductive function. Kisspeptin was originally discovered as a tumor metastasis suppressor gene (76), but since has been shown to be a potent stimulator of GnRH release. Kisspeptin is part of a family of RF-amide related peptides (RFRP), a product of the Kiss 1 gene, and a ligand for a protein-coupled membrane receptor, GPR54 (now termed "Kiss1R") (7779). Kisspeptin is a 54 amino acid peptide (kisspeptin/kisspeptin-54) cleaved from an initial 145 amino acid peptide encoded by the Kiss 1 gene and may undergo further proteolytic processing to form short kisspeptin peptides (kisspeptin-14, -13, -10) with similar binding affinities to Kiss1R $(77,78,80)$. The criticality of kisspeptin-Kiss $1 \mathrm{R}$ signaling in reproduction function was first discovered when two independent studies in humans reported that mutations in the Kiss $1 R$ gene resulted in idiopathic hypogonadotropic hypogonadism, which precluded pubertal development, reduced levels of gonadotropins, and caused infertility $(81,82)$. Furthermore, genetic studies using mice with targeted deletion of Kiss $1 R$ or Kiss 1 produced the same phenotypic abnormality of reproductive dysfunction $(81,83,84)$. Thus, kisspeptin involvement in reproductive function appears to be highly critical. 
In virtually all mammals studied to date, kisspeptin neurons are clustered in two distinct brain regions: the POA and $\mathrm{MBH}$. In addition to these, a few smaller clusters of kisspeptin cells are found in other hypothalamic areas (85-88). In sheep, kisspeptin neurons in the POA are scattered medially and do not reside near the wall of the third ventricle as they do in rodents $(85,88,89)$. In the MBH, kisspeptin neurons are found throughout the rostral, medial, and caudal regions of the ARC $(85,88,89)$. Several lines of evidence demonstrate that kisspeptin neurons are steroidsensitive and are involved in the mediation of both positive- and negative- ovarian hormone feedback effects on GnRH neurons, as discussed in greater detail in later sections.

\section{Neurokinin B/NK3R}

The genes that encode NKB and NK3R - TAC3 and TACR3 - are widely expressed throughout the hypothalamus, including the ARC, VMN, and lateral hypothalamic area (LHA) $(90,91)$. While $\mathrm{NKB}$ immunoreactivity in cell bodies is principally found within the ARC in sheep (60) and rats (92), NK3R cell and fiber immunoreactivity is found throughout the septal region, POA, and MBH in sheep (93), rats (94), guinea pigs (95), and humans (94). Although a large percentage of NK3R cells are found in close proximity to GnRH neurons in sheep, no report of colocalization has been published. Additionally, nearly $60 \%$ of NK3R-immunoreactive cells in the ARC are in close contact with NKB fiber terminals (93). Therefore, the regulation of GnRH by NKB occurs via indirect mechanisms, which will be discussed in more detail in a later section. 
Association of the tachykinin NKB with reproduction was first demonstrated in the early 1990's when Naomi Rance, Ph.D. discovered that NKB mRNA expression was significantly increased in the infundibular nucleus (analogous to the ARC in other species) of postmenopausal women (91). Little further work was done on this neuropeptide until 2009, when patients with mutations in TAC3 or TACR3 who presented with hypogonadotropic hypogonadism and infertility (96) similar to the above mentioned phenotypic dysfunction presented in patients with mutations in Kiss 1 gene or KisslR $(81,82)$, were first reported. Along with NKB, other tachykinins such as substance $\mathrm{P}$ (SP) and neurokinin A (NKA) act through three known tachykinin receptors: neurokinin 1 receptor (NK1R), neurokinin 2 receptor (NK2R), and NK3R. All three receptor subtypes are 7 membrane domain receptors that activate the phosphatidylinositol transduction pathway. While these receptors are not exclusively specific for any tachykinin (substance $\mathrm{P}$, neurokinin $\mathrm{A}$, or NKB), each receptor has higher affinities for one tachykinin: NK1R preferentially binds to substance P, NK2R to neurokinin A, and NK3R to NKB (97).

\section{Galanin}

Over the last decade, galanin ( 29 amino acid sequence) has been implicated in the control of GnRH release $(43,98)$. This neuropeptide is widely expressed throughout the central and peripheral nervous systems (56), with the highest concentrations observed in the MBH in numerous species, including rats (99), primates (100), pigs (101), and sheep (102). Galanin has been implicated to play a role in a wide range of neuroendocrine functions. Aside from reproduction, intracerebroventricular or intravenous administration of galanin in rodents (103) and women (104), respectively, stimulates prolactin and growth hormone release. Similarly, intracerebroventricular 
injections of galanin in sheep results in dose-dependent increases in plasma growth hormone concentrations (105).

In the POA, galanin is colocalized with a sub-population of GnRH neurons in female rats (approximately 65\% of GnRH neurons) $(106,107)$ and female primates (approximately $10 \%$ of GnRH neurons) (108). In rodents, this percentage is found to be sexual dimorphic; in males, approximately $20 \%$ of POA GnRH neurons contain galanin immunoreactivity, compared to the previously stated $65 \%$ of $\mathrm{GnRH}$ neurons in females (109). This population is also highly sensitive to steroid environment. During proestrus, significantly higher levels of galanin are found in the POA compared to during estrus (109). Moreover, the incidence of colocalization of GnRH and galanin peptide at the level of single axon terminals in the median eminence was dramatically decreased by ovariectomy (approximately 23\% colocalization), but this was reversed after administration of estradiol (approximately 55\% colocalization). The incidence of vesicular colocalization was also greater in females (45\%) compared to males (3\%) (110). Furthermore, galanin receptor subtype 1 (Gal-R1) has been observed in GnRH neurons in the POA of rats (111) and the presence of galanin close-appositions on GnRH neurons has been shown in rats (109), mice (112), and humans (113).

Galanin is released in pulses into the hypothalamus-pituitary vasculature, with much higher concentrations found in the portal blood supply than in the peripheral circulation in rodents (7-fold difference); the majority of these pulses are coincident with pulses of GnRH (114). Moreover, it has been demonstrated through triple-label immunocytochemical staining that a subpopulation of GnRH neurons coexpressing galanin in the POA is activated during the LH surge (as indicated by 
the presence of nuclear c-Fos) in female rats (115). Additionally, administration of galanin to ovariectomized animals has no significant effect on LH secretion. However, after implantation of progesterone and estrogen, stimulation of LH release was observed (116).

In sheep, the amount of colocalization between GnRH and galanin does not appear to be altered by steroids (117), however, the number of galanin fiber close-appositions to GnRH cell bodies was increased in the presence of estradiol (56). Furthermore, the number of galanin-immunoreactive neurons in a subpopulation in the caudal part of the POA was increased after administration of estradiol compared to controls; a report that was consistent with the discovery of ER $\alpha$ expression in galanin neurons (73). Galanin receptor subtypes 1 to 3 (Gal-R1, Gal-R2, Gal-R3) have also been detected throughout the POA, hypothalamus, and pituitary gland (74), and a subset of GnRH neurons have been shown to express Gal-R1 mRNA (similar to what is seen in female rats) (75). Although Gal-R2 has been observed in a large number of neurons throughout the hypothalamus, it has not been shown to colocalize with GnRH in sheep (118).

\section{The GnRH Pulse generator}

The current model for GnRH pulse generation centers on KNDy neuronal activity within the ARC nucleus. Several neuroanatomical characteristics of KNDy neurons led to the hypothesis that these neurons play an important role in driving episodic GnRH release: 1) KNDy neurons contain two stimulatory peptides, kisspeptin and NKB, and one inhibitory peptide, dynorphin, as well as ER $\alpha$;

2) They express receptors for NKB, neurokinin 3 receptor (NK3R) (93), and dynorphin, א-opioid 
receptor (KOR) (119), suggesting extensive reciprocity and allowing for autocrine and paracrine actions within this interconnected population of cells; 3) Afferents from KNDy neurons extend to the POA where they contact $40 \%$ of GnRH cell bodies, and to the MBH where they project to $60 \%$ of MBH GnRH neurons; and 4) KNDy neurons form a vast interconnected network (120). Due to the observation that GnRH neurons contain receptors for kisspeptin (GPR54 or kiss1r) (121), but not receptors for NKB (NK3R), it was proposed that kisspeptin, but not NKB, output from KNDy neurons is responsible for stimulating pulsatile GnRH release (Fig. 1.2.). Thus, within the KNDy network, NKB and dynorphin act in tandem to initiate (NKB) and terminate (dynorphin) release during each GnRH pulse (122). During pulse onset, the initial release of NKB stimulates KNDy neuron activity in an autocrine and paracrine manner. Kisspeptin is secreted from KNDy neurons, which acts to stimulate GnRH neurons, resulting in a subsequent GnRH pulse. Within a few minutes, dynorphin release inhibits KNDy neuron activity, and after approximately 5 minutes, kisspeptin release ceases and the GnRH pulse is terminated. Although these observations make KNDy neurons strong candidates for driving pulsatile GnRH release, the possibility still exists that other neurotransmitters or neuropeptides may contribute to steroidal regulation of pulsatile $\mathrm{GnRH}$ and $\mathrm{LH}$ release. 
Figure 1.2. Model for control of KNDy neural activity proposed to drive episodic GnRH secretion
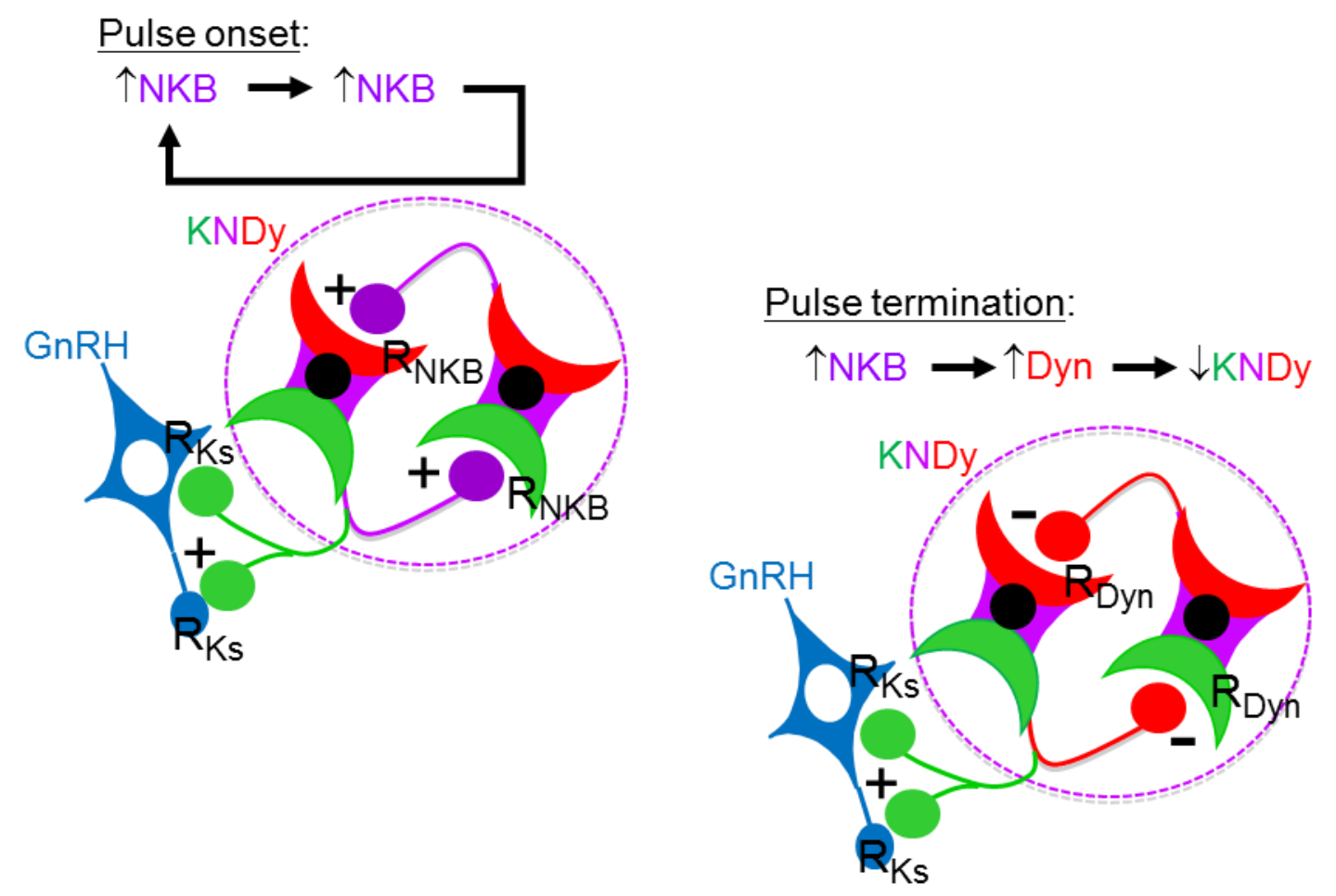

Figure 1.2. Model of synchronous activity among KNDy cells to regulate GnRH pulse frequency. Pulse onset begins with NKB (purple) acting via NK3R within the KNDy network (purple dashed line) to stimulate the release of kisspeptin (green). Kisspeptin acts via KISS1R to stimulate the release of GnRH (blue) and activate surrounding unidentified neurons that contain KISS1R (gray). Pulse termination begins with dynorphin (red) release from KNDy neurons that acts via KOR to inhibit activity in KNDy neurons and/or GnRH neurons and/or the unidentified KISS1Rcontaining neurons. $\mathrm{R}_{\mathrm{dyn}}$, kappa-opioid receptor; $\mathrm{R}_{\mathrm{Ks}}$, KISS1R; $\mathrm{R}_{\mathrm{NKB}}$, NK3R. From Nestor et al. 2018 (122). 


\section{KNDy Neurons and Steroid Feedback}

Several studies have produced evidence that implicate individual KNDy neuron components (i.e., kisspeptin, NKB, or dynorphin) as mediators of ovarian steroid feedback. Recent work has established a role for kisspeptin ARC neurons in mediating the negative feedback effects of estrogen (123). In situ hybridization studies have demonstrated that removal of endogenous estradiol release by OVX increases, and estradiol administration decreases, the number of Kiss 1expressing neurons in the ARC of many species $(88,123,124)$. The negative feedback effects of estradiol on ARC kisspeptin neurons are controlled via ER $\alpha$ (125), acting through a non-classical mechanism that does not involve estrogen response element (ERE) signaling (126). Increases in Kiss 1 mRNA have been observed after OVX in primates (127), sheep (128), and rats (129), while, decreases in Kiss 1 mRNA have been observed after estradiol treatment in sheep (130). Furthermore changes in ARC Kiss1 mRNA displayed a strong positive correlation with changes in LH pulse amplitude in sheep (130). These findings provide evidence that estradiol acts to inhibit GnRH/LH pulse amplitude by suppressing kisspeptin release from KNDy neurons.

In contrast to estradiol, kisspeptin does not appear to mediate progesterone negative feedback. Rather, several reports have provided evidence for dynorphin in this role. As previously mentioned, GnRH/LH pulse frequency is reduced by progesterone. This negative feedback is generally accepted to occur through the inhibitory actions of endogenous opioids $(13,43,131)$ such as dynorphin. Data that support this hypothesis include the findings that nearly all KNDy neurons contain PR (59), administration of a KOR antagonist into the MBH increases LH pulse frequency in luteal phase ewes (71), OVX decreases ARC prepro-dynorphin mRNA (132), and 
administration of RU486 (PR antagonist) into the ARC disrupts progesterone negative feedback (130). These findings provide evidence that progesterone acts to effect $\mathrm{GnRH} / \mathrm{LH}$ pulse frequency by acting through dynorphin.

\section{The GnRH/LH Surge}

The rise in estradiol during late follicular phase is now generally accepted as the ovarian signal that induces GnRH and LH surges. The mechanism by which estradiol simulates GnRH release is still poorly understood, but some important aspects have been defined based on early discoveries. The first is that local administration of estradiol-containing implants into the VMN-ARC region, but not other locations within the hypothalamus, induces surge secretion of GnRH and LH in sheep (133). The second is that there is no neuroanatomically-distinct population of GnRH cells identified to date that participates during the surge; c-Fos expression is found in approximately $40 \%$ of GnRH cells regardless of location (including the POA and $\mathrm{MBH}$ ) during an estrogeninduced surge (134). Finally, knife cuts through the rostral hypothalamus (i.e. deafferentation of MBH GnRH neurons) either block or greatly reduce an estrogen-induced surge (135). These observations provide a foundation for the hypothesis that estradiol acts in the MBH to evoke a signal that eventually ends with a massive release of GnRH.

The surge induction process has been hypothesized to occur in three stages (136). The first stage is activation, described as a period lasting between 4 and 14 hours during which estradiol must be

present and acts as the "activating" agent of the surge induction process. The second stage, called 
transmission, is defined as the 6 to 8 hour period after the activation stage that does not require the presence of estradiol (after activation, and once this process has started, signaling within the hypothalamus becomes independent of estradiol) (43). The third stage is the called the secretory phase. During this period, GnRH secretion has been initiated and is likewise estradiol-independent.

Many neurotransmitters have been implicated in the induction of the GnRH surge. Systems with largely correlative data supporting a role in controlling $\mathrm{GnRH}$ surge release include dopaminergic and somatostatinergic activity within the VMN and galaninergic activity in the POA and ARC. Levels of the dopamine metabolite 3,4-dihydroxyphenylacetic acid significantly increase in the VMN coincident with the LH surge in estrogen-treated ovariectomized ewes, with levels remaining elevated $10-20$ hours post-estrogen stimulus. Moreover, inhibition of catecholamine (dopamine and NE) synthesis in the VMH delays the onset and time to peak of the LH surge, as well as attenuates the overall response (137). Somatostatin neurons in the VMN contain ER $\alpha$ (61) and acute estradiol treatment increases levels of prepro-somatostatin mRNA by approximately $50 \%$ in the VMN (138). Additionally, c-Fos expression is increased in somatostatin neurons during the naturally occurring LH surge and after an estrogen-stimulus during anestrus in ewes (139). More recently, however, administration of a somatostatin receptor agonist, octreotide, or an antagonist, CYN154806, into the third ventricle during an estrogen-induced surge had no effect on the timing or magnitude of the LH surge in ewes (140). Depending on the stage of cycle, galanin (and its receptors) is differentially expressed in numerous areas in sheep, demonstrating that this neuropeptide is highly influenced by steroids (56). Galanin-immunoreactive cell numbers in the POA are elevated in the presence of surge-inducing levels of estradiol and more than $50 \%$ of these neurons contain ER $\alpha$ in ewes (73). Moreover, galanin mRNA expression in the POA is highest 
during mid-follicular phase at the start of the GnRH surge (56). Collectively, these data lead to the proposition that this neuropeptide could participate in the surge induction process during the activation and/or secretory phase.

Other neurotransmitters/neuropeptides that have also received significant attention are $\beta$ endorphin, NE, kisspeptin, and NKB. As previously discussed, endogenous opioid peptides (EOP), such as $\beta$-endorphin, are inhibitory to $\mathrm{GnRH}$ release. Because of this, the hypothesis was developed that withdrawal of an EOP inhibitory signal may be permissive to the onset of GnRH release. Evidence for this is found in the observations that levels of $\beta$-endorphin expression decrease during surge activation (141), concentrations of $\beta$-endorphin in the ME increase during the transmission phase (142), and then decrease during the secretory phase when the GnRH surge occurs (143). Additionally, administration of the opioid receptor agonist morphine or DAMGO ([D-Ala ${ }^{2}, N-\mathrm{MePhe}^{4}$, Gly-ol]-enkephalin), another mu EOP receptor agonist, to adult ewes, delayed, but did not block, the onset of estrus and the GnRH surge (144,145). Taken together, these pharmacological data indicate that EOP withdrawal is necessary, but not sufficient, for the LH surge. However, administration of the EOP receptor antagonist, naloxone, had no effect on the GnRH surge (144). Early evidence for noradrenergic involvement in the GnRH surge is found in the observations that track tracer injections in the DBB/rPOA of the sheep brain resulted in retrograde labelling of cells with FlouroGold that colocalized with estrogen receptor in the rostral and medial regions of the A1 field of the brain stem (146). Additionally, A1 noradrenergic cells in the brain stem were acutely stimulated by estrogen injected in OVX ewes (147). Furthermore, NE release in the POA during the transmission phase (148) and ME during the secretory phase (149) is increased, and blockade of A1-noradrenergic action reduces the magnitude of the LH 
surge (150). These findings substantiate the notion that noradrenergic cells found in this region of the brain stem may be involved in estrogen positive feedback.

Recent published reports have postulated that kisspeptin contributes to, but is not fully responsible for, activation of the GnRH surge. Similarly to what is shown with blockade of A1-noradrenergic action, kisspeptin antagonist infusion reduces the magnitude of the LH surge by approximately $50 \%$ in ewes during an estrogen-induced LH surge (151). Moreover, estrogen treatment stimulates kisspeptin expression in the population of kisspeptin cells found in the POA (152), which is similar to what is reported in the AVPV of rodents (153), and raises the possibility that POA kisspeptin neurons in sheep participate in the estrogen-induced preovulatory LH surge (152). Importantly, as previously mentioned, estrogen acts in the $\mathrm{MBH}$, not the POA, to initiate the LH surge in sheep (133). As such, there is supporting evidence that POA kisspeptin cells are indirectly activated by estrogen positive feedback. Immunohistochemical studies have shown that levels of Kissl mRNA and kisspeptin/c-Fos colocalization in the caudal ARC (KNDy neurons) are significantly elevated 1 hour post-estrogen stimulus (15 to 19 hours before the resulting LH surge) in OVX ewes, and tend to increase during the late-follicular phase (1 to 2 hours before the resulting LH surge) in intact ewes (154). During the LH surge, increased levels of c-Fos expression are found in POA kisspeptin and GnRH neurons in intact cycling ewes $(89,155)$. Thus, there is supporting evidence that kisspeptin neurons in the POA act during the secretory phase of the GnRH surge induction process, while kisspeptin neurons in the ARC participate during both the activation and secretory phases. 
As discussed previously, negative feedback effects of estrogen are likely mediated through kisspeptin. Briefly, in the ARC, neuronal expression of kisspeptin increases after OVX, but cell numbers return to normal after estradiol-containing implants in OVX ewes $(88,156)$. During the late follicular phase, kisspeptin gene expression and protein content in the middle and caudal ARC increases (121) and, during an estrogen-induced surge, show increased levels of c-Fos $(89,157)$. The mechanisms whereby kisspeptin may be involved in both negative and positive estradiol feedback remains to be determined. The most feasible explanation is that positive feedback events result from transient activation of kisspeptin cells, while negative feedback events result from continuous inhibition of kisspeptin cells (158). Thus, as reported by Smith et al. (154), large, acute increases in estradiol, such as during the LH surge, result in the activation of kisspeptin neurons in the ARC. In contrast, constant, low levels of estradiol result in the inhibition of kisspeptin expression in the ARC (121). In the AVPV in rodents and POA in sheep, administration of estradiol increases the expression of Kiss1 mRNA $(156,159)$, thus providing evidence for a similarity in the currently-held hypotheses of the activity of kisspeptin neurons in the POA (AVPV region) of rodents and sheep.

Numerous lines of evidence implicate another KNDy peptide, NKB, in the stimulation of the GnRH and LH surge in ewes. Microimplantation of senktide, a NK3R agonist, into the ovine retrochiasmatic area $(\mathrm{RCh})$ elicits surge-like increases in LH $(69,70)$. Conversely, pharmacologic blockade of NK3R signaling within the ovine RCh reduces the amplitude of the LH surge by approximately 50\% (70). These findings demonstrate that NK3R activation in the RCh is essential for full expression of the preovulatory LH surge. To further support this hypothesis, NK3-SAP injection dramatically decreased the numbers of NK3R-containing neurons in the RCh and reduced 
the amplitude of an estrogen-induced LH surge by approximately 50\% (Goodman et al., 2018, International Congress of Neuroendocrinology Abstract). NK3-SAP is a conjugate of saporin, a ribosome-inactivating toxin, and $\left[\mathrm{MePhe}^{7}\right]-\mathrm{NKB}$, a potent and selective NK3R agonist, used to selectively ablate NK3R neurons. Further, microimplantation of senktide into the ovine RCh induces an increase in c-Fos expression in kisspeptin neurons of the ARC and infusion of a Kiss1R antagonist, Kp-271, completely blocks the surge-like increase in LH induced by RCh senktide administration (160). Neurons in the RCh project directly to KNDy neurons (160), and as such, there is supporting evidence that NK3R neurons in the RCh (the phenotype of which remain unknown) innervate KNDy neurons in the ARC and provide a circuit by which NKB acts in the $\mathrm{RCh}$ to stimulate kisspeptin release, culminating in a GnRH surge during the secretory phase of the induction process.

To summarize, multiple neural systems are suggested to participate in the estrogen-induced LH surge in the ewe: during the activation phase, estradiol acts in the ARC to stimulate kisspeptin release from KNDy neurons, and potentially in the brainstem to stimulate NE release. During the transmission phase, increases in stimulatory input from NE and kisspeptin to GnRH neurons is limited by increases in inhibitory inputs from $\beta$-endorphin. As the inhibitory signal from $\beta$ endorphin wanes, NK3R-containing neurons in the RCh are activated by NKB and stimulate the kisspeptin release from KNDy neurons that drives GnRH secretion during the surge. During the secretory phase, additional stimulation is supplied by the population of kisspeptin cells in the POA that are innervated by ARC KNDy neurons. Other potential supplementary input is provided by noradrenergic efferent neurons in the A1 region of the brainstem (149). Activity involving the population of NK3R-containing cells in the RCh are the focus of work discussed in this dissertation 
and are depicted in Figure 1.3. Specifically, NK3R activation within the RCh is necessary for expression of the LH surge and these cells act to increase GnRH/LH secretion during a surge by activating release of kisspeptin from KNDy cells in the ARC. 
Fig 1.3. Schematic representation of connectivity between neurons implicated in the luteinizing hormone surge in sheep

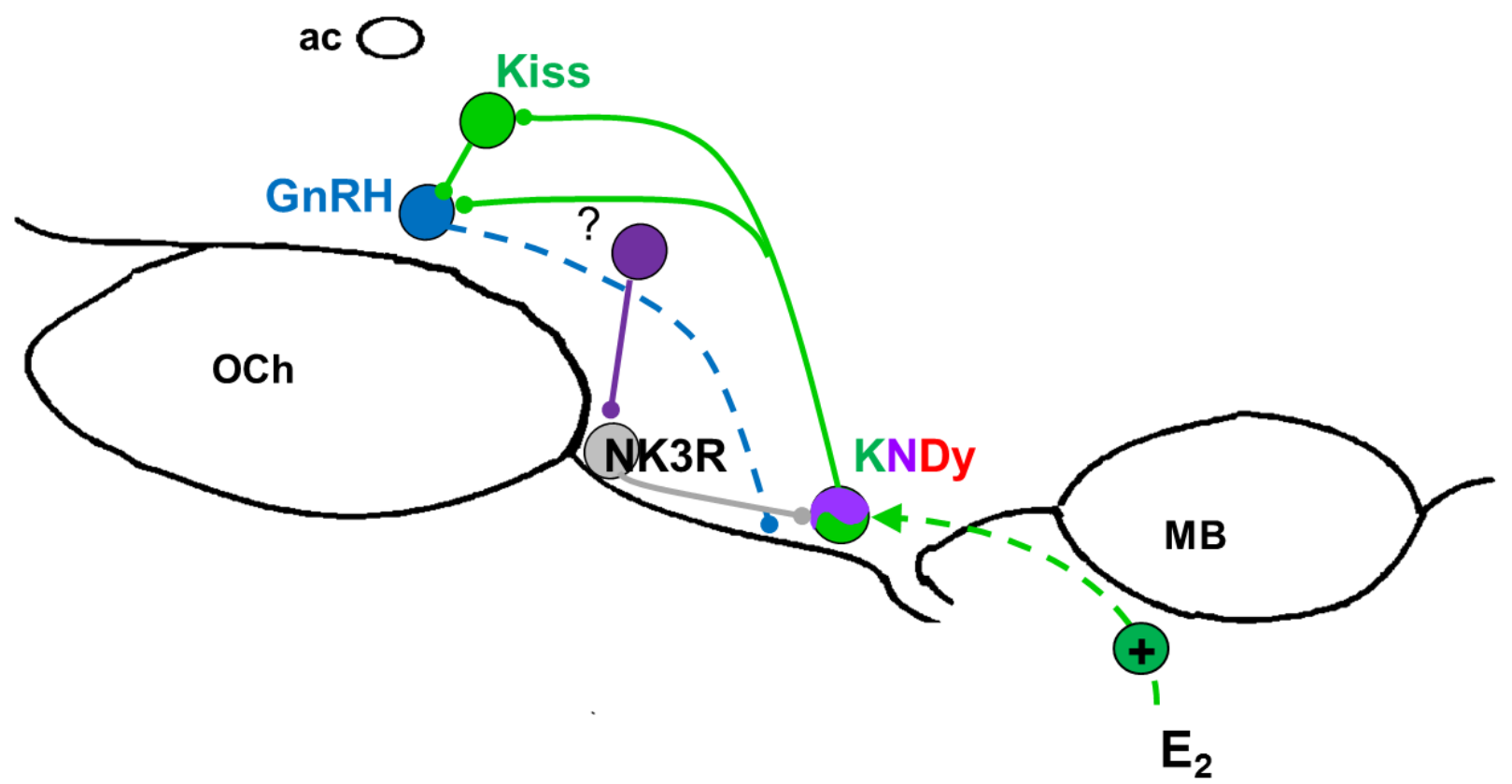

Figure 1.3. NK3R-containing neurons (grey) in the RCh project to KNDy neurons in the ARC. KNDy neurons coexpress kisspeptin (green), NKB (purple) and dynorphin (Dyn) (red), and innervate kisspeptin (green) and GnRH neurons (blue) in the POA. The source of NKB that activates NK3R-containing neurons in the RCh is currently unknown. ac, anterior commissure; inf, infundibular recess; OCh, optic chiasm; MB, mammillary body; $\mathrm{E}_{2}$, estrogen. 


\section{Mechanisms for Sexual Differentiation of Reproductive Function}

The development of sexual differentiation of reproductive function has been thoroughly investigated by examining both prenatal organization and activation of postnatal effects of gonadal steroids. Early mammalian development is characterized by a series of "critical periods" during which the brain is sensitive to the effects of steroids that cause sex differences in behavior and neuroendocrine development during adulthood. Permanent, organizational changes in neural and neuroendocrine systems that occur during gestation are referred to as prenatal organization and many occur in response to steroid influences. In comparison, postnatal activation is described as transient, activational changes that result from exposure to these steroids during adulthood and are reversible (161). Normal sexual differentiation of the brain is regulated by testicular testosterone secretion during the prenatal period in humans, non-human primates, sheep, and guinea pigs, but is not completed until the neonatal period in rodents (162). At birth, without the intervention of testosterone, the resultant offspring will display a female-typical phenotype by default. However, under the direction of the SRY gene (sex-determining region Y) on the Y chromosome, the gonads will differentiate into testes and the subsequent production and secretion of testosterone and antiMullerian hormone $(\mathrm{AMH})$ results in the regression of the female reproductive tract and development of the male reproductive tract, leading to a male-typical phenotype. In addition, neuroanatomical changes in neural and neuroendocrine systems underlie the masculinization of sexual behavior and defeminization of the estrogen-induced GnRH/LH surge (163), defining differences between male and female organisms. 
A number of animal models have been established to investigate how steroids alter postnatal reproductive neuroendocrine function. These studies have taken the form of examining the effect of exposing females to exogenous testosterone (or other androgens such as dihydrotestosterone (DHT)) during development and/or removing/blocking endogenous testosterone in males during development and then investigating the neural pathways by which these specific effects are mediated. As mentioned above, within these critical periods exists windows in which specific traits may be susceptible to exposure to steroids. In rodents and other species with short gestation periods, the majority of these developmental periods occur postnatally, with sexual differentiation of the brain arising only a few days after birth (164). Early studies demonstrated that increases in androgens are detectable in rats at day 15.5 of gestation and peak at day 18 of gestation and immediately after birth $(165,166)$. This "masculinization programming window" is essential for differentiation of sexual behavior and neuroendocrine function in these animals $(163,165,166)$, and also normal male phenotype, such as differentiation of the internal reproductive tract (epididymis, vas deferens, seminal vesicles, and prostate) and external genitalia (penis, scrotum, and perineum) (167). In comparison, sheep, and other species with long gestation periods (i.e., non-human primates and guinea-pigs), experience these critical periods prenatally (164). Exposure of female sheep fetuses to levels of testosterone (weekly; $200 \mathrm{mg}$ testosterone cypionate) similar to that observed in males while in utero (between days 30 and 86 of a 147-day gestation), results in formation of male genitalia and development of the male reproductive tract (161). Comparably, in male guinea pigs, increases in testicular androgen levels occur between days 28 to 36 of gestation and correspond to a critical window responsible for sexual differentiation of the brain (168). 
The question still exists whether exposure to androgen or estrogen while in utero is responsible for male patterns of GnRH release, and whether the absence of these steroids is responsible for female pattern of GnRH release. Several experiments in sheep over the last few decades have demonstrated the importance of exposing fetal brains to the correct steroid environment and the reproductive outcomes after birth if they are exposed to the incorrect steroid environment. Particularly, the impact of in utero androgen exposure on steroid negative feedback can be seen in studies examining sex differences in the pubertal decrease in sensitivity to steroid feedback inhibition on tonic GnRH release. Normal gonad-intact females - or agonadal females treated with estrogen implants - are highly sensitive to small amounts of estrogen prior to puberty, which results in low concentrations of GnRH and basal concentrations of circulating $\mathrm{LH}$ until the age of first ovulation (around 30 weeks of age) $(161,169,170)$. In contrast, normal gonadal and steroidclamped agonadal males exhibit increases in tonic LH secretion much earlier (around 7 to 8 weeks of age), leading to the conclusion that the inhibitory brake applied prepubertally to GnRH release is removed much earlier in males compared to females (Fig. 1.4). Numerous studies have employed in utero steroid exposure techniques, as discussed above, to examine the influence of prenatal androgen exposure on the age of which the pubertal decrease in sensitivity to steroid feedback inhibition of tonic GnRH release occurs. Testosterone administered weekly to pregnant females from days 30 to 90 of gestation resulted in female offspring exhibiting early pubertal increases in GnRH and LH release that were similar to what is observed in normal males (171). Furthermore, depending on the dose of testosterone, the occurrence of the pubertal increase in LH release differed. A dose of $200 \mathrm{mg}$ of testosterone resulted in a pubertal increase in LH around 10 weeks of age, $80 \mathrm{mg}$ resulted in advancement to 16 weeks, and $30 \mathrm{mg}$ resulted in no advancement (Fig. 1.5) (172). There also seems to be a great deal of plasticity in the "critical period." 
Administration of $200 \mathrm{mg}$ of testosterone to pregnant females treated from day 30 to 51 (early) or 65 to 86 (late) days of gestation resulted in female offspring that presented with external genitalia that differed at birth (early, masculinized; late, normal), but advanced the increase in pubertal LH secretion to the same age: LH secretion increased at $19.3 \pm 1.2$ (early) and $20.4 \pm 0.8$ (late) weeks (173). Furthermore, administration of dihydrotestosterone (DHT), a potent, non-aromatizable androgen, to pregnant females resulted in pubertal $\mathrm{LH}$ increases that were similar to what is observed in normal males or testosterone-treated females, suggesting that this was androgendependent and not due to conversion of testosterone to estrogen by aromatase. Co-treatment of testosterone or DHT treated females with flutamide, an androgen receptor antagonist, reversed the reduced sensitivity to estrogen negative feedback normally observed in these animals (174). These findings lead to the conclusion that the duration of the brake applied to GnRH release prior to puberty is, at least in part, organized before birth by the actions of androgens. 
Figure 1.4. Timing of puberty in spring-born male and female lambs, and corresponding changes in LH secretion.
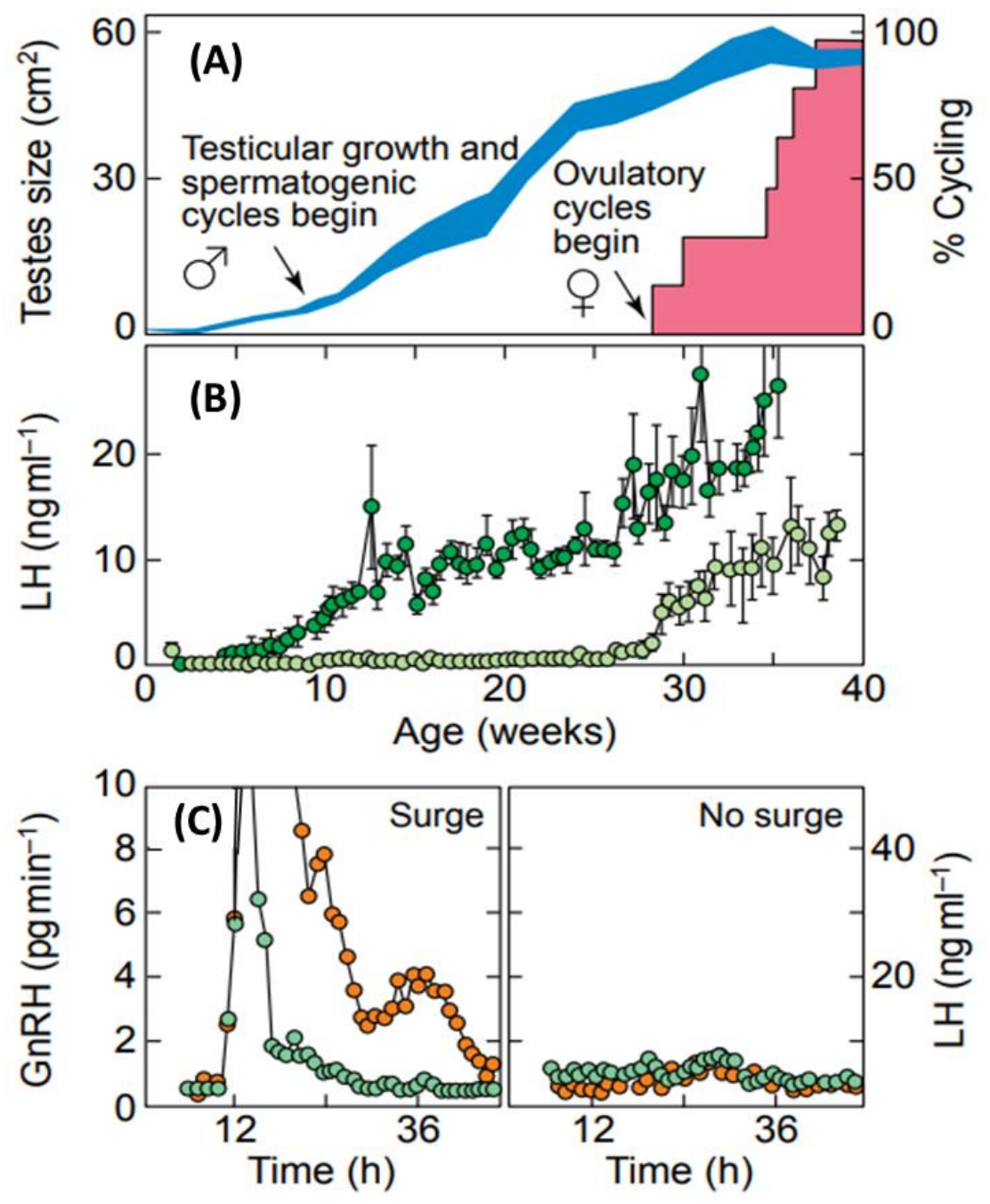

Figure 1.4. Timing of puberty in spring-born male and female lambs, and corresponding changes in LH secretion. (A) Indices of puberty onset in gonad-intact males (sperm production) and females (ovulation). (B) Circulating LH concentrations from gonadectomized estradiol-treated male (dark green) and female (light green) lambs. (C) GnRH and LH concentrations in response to a surgeinducing dose of estradiol (time zero) from a representative female lamb (left) and male lamb (right); GnRH (orange circles), LH (green circles). Modified from Wood and Foster, 1998 (161). 
A major sex difference that exists between males and females is the occurrence of the LH surge with males unable to respond to positive feedback actions to estrogen. Similar to what has been discussed above with tonic GnRH and $\mathrm{LH}$ release, the question remains whether the prenatal actions of steroids play a critical role in controlling differentiation of the surge mode of GnRH secretion. The LH surge is inoperable in male sheep due to failure to generate adequate and sustained levels of GnRH release (21). After administration of surge-inducing levels of estrogen to normal females, a surge in GnRH and subsequent LH release clearly occurs; this phenomenon is not observed in males or females exposed prenatally to testosterone (21). Within the "critical period," there seems to be great plasticity in terms of controlling the development of the surge system (depicted in Fig. 1.5). Short periods of testosterone treatment (3 weeks) beginning on day 30 (early) or 65 (late) resulted in female offspring that could mount delayed LH surges after acute estradiol stimulation: the surge of LH peaked at $29.8 \pm 1.6$ (early) and $31.8 \pm 1.3$ (late) hours postestrogen, relative to normal time-to-peak, which is approximately 24 hours (173). Interestingly, administration of DHT to pregnant females (days 30 to 90 of gestation) resulted in female offspring that were able to produce $\mathrm{LH}$ surges, despite masculinization of tonic $\mathrm{GnRH}$ secretion, leading to the conclusion that the estrogenic actions of testosterone (testosterone is aromatized to estrogen) may be responsible for defeminization of the surge mechanism in males (175). At the time, these differential findings led to the conclusion that development of the neural circuitry for the tonic and surge modes of GnRH secretion occur independently from one another. However, more recently, dual organizational effects of these steroids have been postulated to exist during development. Administration of testosterone to pregnant ewes between days 30 to 90 of gestation and daily treatment with the androgen antagonist flutamide (this will block androgenic programming of testosterone) starting at 8 weeks of age resulted in female offspring that exhibited partial reduction 
of the LH surge amplitude in response to acute estradiol stimulation. Therefore, the timing of the surge may be programmed by estrogenic pathways, while the magnitude of the surge may be programmed, in part, by androgenic pathways (176). 
Figure 1.5. Effects of androgen treatment in utero on external genitalia, neuroendocrine sexual maturation, and the $\mathrm{LH}$ surge in female lambs.

(a)

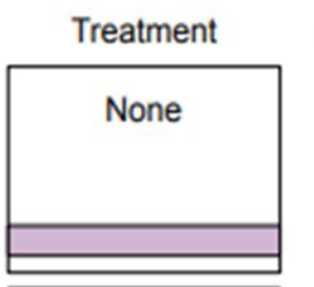

(b)

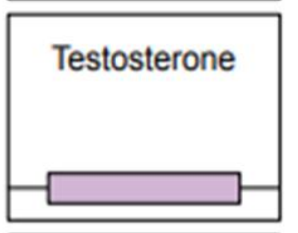

(c)

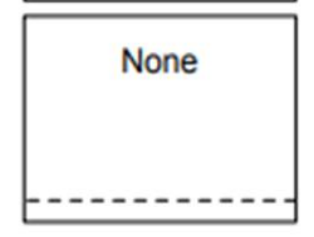

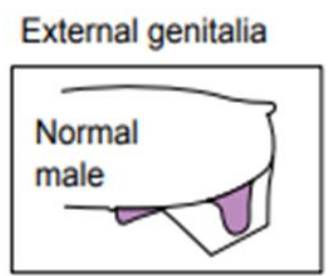
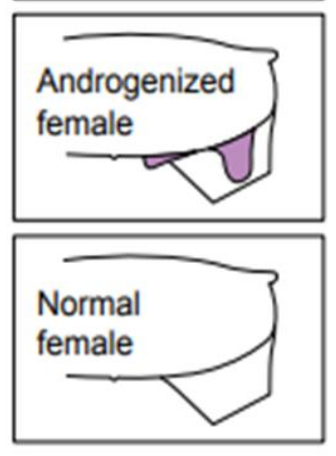
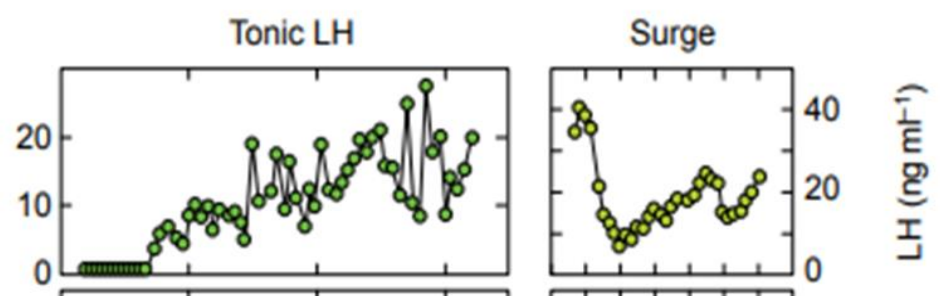

Figure 1.5. Effects of androgen treatment in utero on external genitalia, neuroendocrine sexual maturation, and the LH surge in female lambs. Column 1: schematic of type of androgen treatment. Column 2: schematic sagittal section through the hind-quarters of representative male, female and androgenized female lambs illustrating the position of the penis, scrotum or vulva. Column 3: LH concentrations in gonadectomized estradiol-treated lambs from samples collected twice per week. Column 4: LH response to follicular phase concentrations of estradiol over 60 hours. (A - C) Androgenization occurred during the entire critical period (171). (A) Normal male lamb. (B) Female lamb treated with high dose testosterone from day 30 to day 86 of gestation. (C) Normal female lamb.. Modified from Wood and Foster, 1998 (161). 
Prenatal exposure to steroids produces differing reproductive outcomes in adulthood. Early studies in females of the Dorsett breed demonstrated that exposure to testosterone from 30 to 90 days during gestation resulted in a period of reproductive cyclicity followed by a progressive decline in reproductive cyclicity that eventually led to anovulation during adulthood (177). Other breeds including Suffolk ewes, demonstrate similar responses $(178,179)$. Moreover, testosterone exposure during different windows of the "critical period" leads to differing chronic, sustained effects. Most females treated with testosterone between days 60 to 90 of gestation cycled normally during the first and second breeding season, where those treated between days 30 to 90 became anovulatory during the second breeding season (177). This observation led to the conclusion that the steroid environment during the critical period not only affects the establishment of neuroendocrine feedback systems, but may also alter ovarian development which starts approximately on day 30 in ewes. Furthermore, the timing of neuroendocrine puberty onset in androgenized agonadal, estrogen-implanted females differs from that of androgenized gonadal females (177). Prenatal testosterone administration from days 60 to 90 resulted in a timing of puberty in ovary intact females that occurred at $31.8 \pm 0.6$ weeks, compared to $21.7 \pm 1.9$ weeks in agonadal estrogen-implanted females. Prenatal testosterone administration from days 30 to 90 resulted in a timing of puberty in ovary intact females that occurred at $30.6 \pm 1.3$ weeks, compared to $12.4 \pm 0.9$ weeks in agonadal estrogen-implanted females (177). In these instances, two predominant questions persist: 1) why do reproductive cycles occur in lambs during the first and second breeding season after prenatal exposure to androgens?, and 2) what discrepancies exist that allow for differences in observations between the gonadectomized and ovary-intact, prenatal testosterone-treated females? In both cases, these outcomes are unexpected, given the observations from the well-studied experimental model for postnatal estrogen implantation and the resultant 
suppressive effects on GnRH release. To address the first question, intact prenatally androgenized females are most likely capable of generating subtle ovulatory LH signals that may persist for one or two breeding seasons, as evidenced by progestogenic cycles and the appearance of ovarian corpora lutea (177). In the case of gonadal versus agonadal (OVX + estrogen) prenatal androgenized females, the pattern of release for estrogen seems to be a likely explanation. Administration of constant, relatively high levels of estrogen by implants, compared to endogenously fluctuating low levels of estrogen, after birth may result in further disruption of the neural circuitry controlling the GnRH surge and tonic systems, rendering surge generation inoperable and reproductive cycles disrupted in androgenized estrogen-implanted females $(180,181)$. Furthermore, there is evidence that chronic estrogen exposure can disrupt steroidinduced LH surges in rodents (182) and cows (183), in part by inactivating GnRH neurons (182). These findings lead to the conclusion that endogenous postnatal estrogen release is required to complete sexual differentiation, particularly at the level of the GnRH surge system.

At a neuroanatomical level, the basis for sexual differentiation of the control of GnRH secretion remains to be fully elucidated. GnRH neurons are not sexually dimorphic with respect to number, distribution, or gross morphology. Therefore, sexual dimorphism most likely exists in factors located upstream of GnRH neurons that reside locally or from within other areas of the brain. Early studies demonstrated that in female lambs, GnRH perikarya receive twice the number of synaptic contacts than those found in male lambs of the same age: $3.6 \pm 0.7$ versus $1.6 \pm 0.3$ synapses/100 micron of plasma membrane. Furthermore, the number of synapses on GnRH neurons from androgenized female lambs was similar to what was observed in males, $1.5 \pm 0.5$ synapses/100 micron plasma membrane (184). Organizational effects of gonadal steroids clearly influence sex 
differences in synaptic input to GnRH neurons; the phenotype of these contacts, however, still remains unclear. KNDy neurons located in the ARC are highly sensitive to steroids, which makes this population of cells a likely target of the organizational effects of steroids. In the ARC, twice the number of NKB cells are observed in adult female sheep compared to males or androgenized females $(60,185)$. Moreover, a greater number of kisspeptin, dynorphin, and PR-positive cells are found in adult females compared to adult male sheep $(185,186)$. Interestingly, kisspeptin cell numbers in the ARC have not been shown to be affected by testosterone treatment in utero because androgenized females do not show reduced numbers compared to normal females (186). NK3Rpositive cells in the ARC are also reduced in androgenized females compared to normal females. This decrease was postulated to be primarily due to changes within the above-mentioned KNDy cell population, as single-labeled NK3R cells did not differ between the two groups (187). These findings add an additional layer of sexual dimorphism, as there is clear evidence that the organizational effects of steroids result in a combined reduction of both ligand and receptor components of KNDy/NK3R signaling. This potentially contributes further to the inability of males to generate a GnRH surge.

\section{Objectives}

The neuropeptides NKB and kisspeptin are critical for fertility in humans and potent stimulators of $\mathrm{GnRH}$ and $\mathrm{LH}$ secretion in primates and sheep. Administration of a selective NK3R agonist within the $\mathrm{RCh}$ results in surge-like release of $\mathrm{LH}$ and increased cellular expression of Fos in kisspeptin neurons in the ARC of female sheep. Based on these findings, we concluded that NKBresponsive neurons in the $\mathrm{RCh}$ act to stimulate $\mathrm{GnRH}$ secretion by inducing kisspeptin release 
from neurons in the ARC. Furthermore, the true phenotype of NK3R-containing neurons in the $\mathrm{RCh}$ has yet to be elucidated. However, one potential neurotransmitter co-expressed in these neurons is galanin. The LH surge, in many species, is sexually dimorphic, occurring in females but not in males. Thus, investigating differences between sexes in specific brain regions provides an approach to test areas implicated in the control GnRH/LH surge secretion. Given this, I pursued the following objectives:

1. To determine if sexual dimorphism in the response to NK3R activation exists within the RCh. Using young males and females exposed to artificial follicular phases, we examined if there were differences in LH secretion following senktide microimplant placement within the RCh on LH secretion.

2. To determine whether there are fewer NKB-containing terminals within the RCh of males than in females, we characterized the expression of NKB and NK3R in the RCh of male and female lambs collected during surge induction.

3. To determine if sexual dimorphism exists for NK3R, NKB, or kisspeptin expression in the RCh and ARC, we assessed immunopositive cell numbers in tissue collected from acutely gonadectomized male and female lambs during surge induction.

4. To determine whether galanin stimulates LH secretion in ewes, we injected galanin icv to anestrous and luteal phase female sheep. Furthermore, we characterized the expression of galanin within the RCh. 
5. To determine whether galanin participates in the LH surge of female sheep, ewes were infused icv with a non-specific galanin receptor antagonist, galantide, during surge induction. 


\section{References:}

1. Clarke IJ, Cummins JT. The temporal relationship between gonadotropin releasing hormone $(\mathrm{GnRH})$ and luteinizing hormone $(\mathrm{LH})$ secretion in ovariectomized EWES. Endocrinology 1982;111(5). doi:10.1210/endo-111-5-1737.

2. Caraty A, Fabre-Nys C, Delaleu B, Locatelli A, Bruneau G, Karsch FJ, Herbison A. Evidence that the mediobasal hypothalamus is the primary site of action of estradiol in inducing the preovulatory gonadotropin releasing hormone surge in the ewe. Endocrinology 1998;139(4):1752-1760.

3. Blake CA. A medial basal hypothalamic site of synergistic action of estrogen and progesterone on the inhibition of pituitary luteinizing hormone release. Endocrinology 1977. doi:10.1210/endo-101-4-1130.

4. Plant TM, Krey LC, Moossy J, McCormack JT, Hess DL, Knobil E. The arcuate nucleus and the control of gonadotropin and prolactin secretion in the female rhesus monkey (Macaca mulatta). Endocrinology 1978;102(1):52-62.

5. Krey LC, Lu KH, Butler WR, Hotchkiss J, Piva F, Knobil E. Surgical disconnection of the medial basal hypothalamus and pituitary function in the rhesus monkey. II. GH and cortisol secretion. Endocrinology 1975. doi:10.1210/endo-96-5-1088.

6. Goodman RL. The Site of the Positive Feedback Action of Estradiol in the Rat. Endocrinology 1978;102(1):151-159.

7. Petersen SL, Cheuk C, Hartman RD, Barraclough CA. Medial Preoptic Microimplants of the Antiestrogen, Keoxifene, Affect Luteinizing Hormone-Releasing Hormone mRNA Levels, Median Eminence Luteinizing Hormone-Releasing Hormone Concentrations and Luteinizing Hormone Release in Ovariectomized, Estrogen-Treate. J. Neuroendocrinol. 1989;1(4):279-283.

8. Herbison AE. Multimodal influence of estrogen upon gonadotropin-releasing hormone neurons. Endocr. Rev. 1998. doi:10.1210/edrv.19.3.0332.

9. Lehman MN, Ebling FJP, Moenter SM, Karsch FJ. Distribution of estrogen receptorimmunoreactive cells in the sheep brain. Endocrinology 1993;133(2):876-886.

10. Skinner DC, Caraty A, Allingham R. Unmasking the progesterone receptor in the preoptic area and hypothalamus of the ewe: No colocalization with gonadotropin-releasing neurons. Endocrinology 2001;142(2):573-579.

11. Huang X, Harlan RE. Absence of androgen receptors in LHRH immunoreactive neurons. Brain Res. 1993;624(1-2):309-311.

12. Belchetz PE, Plant TM, Nakai Y, Keogh EJ, Knobil E. Hypophysial responses to continuous and intermittent delivery of hypopthalamic gonadotropin-releasing hormone. Science 1978;202(4368):631-633.

13. Karsch FJ. Central Actions of Ovarian Steroids in the Feedback Regulation of Pulsatile Secretion of Luteinizing Hormone. Annu. Rev. Physiol. 1987;49(1):365-382.

14. Knobil E. The Neuroendocrine Control of the Menstrual Cycle. In: Proceedings of the 1979 Laurentian Hormone Conference.; 1980:53-88.

15. Jackson GL, Kuehl D, Rhim TJ. Testosterone inhibits gonadotropin-releasing hormone pulse frequency in the male sheep. Biol. Reprod. 1991;45:188-194.

16. Goodman RL. Neural systems mediating the negative feedback actions of estradiol and progesterone in the ewe. Acta Neurobiol. Exp. (Wars). 1996;56(3):727-741.

17. Moenter SM, Caraty A, Locatelli A, Karsch FJ. Pattern of gonadotropin-releasing 
hormone $(\mathrm{GnRH})$ secretion leading up to ovulation in the ewe: Existence of a preovulatory GnRH surge. Endocrinology 1991;129(3):1175-1182.

18. Moenter SM, Caraty A, Karsch FJ. The estradiol-induced surge of gonadotropinreleasing hormone in the Ewe. Endocrinology 1990;127(3):1375-1384.

19. Caraty A, Locatelli A, Martin GB. Biphasic response in the secretion of gonadotrophinreleasing hormone in ovariectomized ewes injected with oestradiol. J. Endocrinol. 1989;123(3):375-382.

20. Corbier P. Sexual differentiation of positive feedback: Effect of hour of castration at birth on estradiol-induced luteinizing hormone secretion in immature male rats. Endocrinology 1985;116(1):142-147.

21. Herbosa CG, Dahl GE, Evans NP, Pelt J, Wood RI, Foster DL. Sexual differentiation of the surge mode of gonadotropin secretion: Prenatal androgens abolish the gonadotropin-releasing hormone surge in the sheep. J. Neuroendocrinol. 1996;8(8):627633.

22. VAN LOOK PFA, HUNTER WM, CORKER CS, BAIRD DT. FAILURE OF POSITIVE FEEDBACK IN NORMAL MEN AND SUBJECTS WITH TESTICULAR FEMINIZATION. Clin. Endocrinol. (Oxf). 1977;7(5):353-366.

23. Stormshak F, Estill CT, Resko JA, Roselli CE. Changes in LH secretion in response to an estradiol challenge in male- and female-oriented rams and in ewes. Reproduction 2008;135(5):733-738.

24. Goodman RL, Pickover SM, Karsch FJ. Ovarian feedback control of folliclestimulating hormone in the ewe: Evidence for selective suppression. Endocrinology 1981;108(3):772-777.

25. Mann GE, Campbell BK, McNeilly AS, Baird DT. The role of inhibin and oestradiol in the control of FSH secretion in the sheep. J. Endocrinol. 1992. doi:10.1677/joe.0.1330381.

26. Senger PL. Pathways to Pregnancy and Parturition (sec Ed).pdf. 2003:373.

27. Scaramuzzi RJ, Baird DT, Campbell BK, Driancourt MA, Dupont J, Fortune JE, Gilchrist RB, Martin GB, McNatty KP, McNeilly AS, Monget P, Monniaux D, Viñoles C, Webb R. Regulation of folliculogenesis and the determination of ovulation rate in ruminants. Reprod. Fertil. Dev. 2011;23(3):444-467.

28. Sawyer HR, Smith P, Heath D a, Juengel JL, Wakefield SJ, McNatty KP. Formation of ovarian follicles during fetal development in sheep. Biol. Reprod. 2002;66(4):11341150 .

29. Lundy T, Smith P, O'Connell A, Hudson NL, McNatty KP. Populations of granulosa cells in small follicles of the sheep ovary. Reproduction 1999;115(2):251-262.

30. Bartlewski PM, Beard AP, Cook SJ, Chandolia RK, Honaramooz A, Rawlings NC. Ovarian antral follicular dynamics and their relationships with endocrine variables throughout the oestrous cycle in breeds of sheep differing in prolificacy. Reproduction 1999. doi:10.1530/jrf.0.1150111.

31. Johnson SK, Dailey RA, Inskeep EK, Lewis PE. Effect of peripheral concentrations of progesterone on follicular growth and fertility in ewes. Domest. Anim. Endocrinol. 1996. doi:10.1016/0739-7240(95)00045-3.

32. Landau S, Houghton JAS, Mawhinney JR, Inskeep EK. Protein sources affect follicular dynamics in ewes near the onset of the breeding season. Reprod. Fertil. Dev. 1996. doi:10.1071/RD9961021. 
33. Souza CJH, Campbell BK, Baird DT. Follicular Dynamics and Ovarian Steroid Secretion in Sheep during the Follicular and Early Luteal Phases of the Estrous Cycle'. Biol. Reprod. 1997. doi:10.1095/biolreprod56.2.483.

34. Souza CJH, Campbell BK, Baird DT. Follicular waves and concentrations of steroids and inhibin A in ovarian venous blood during the luteal phase of the oestrous cycle in ewes with an ovarian autotransplant. J. Endocrinol. 1998. doi:10.1677/joe.0.1560563.

35. Campbell BK, Dobson H, Baird DT, Scaramuzzi RJ. Examination of the relative role of FSH and LH in the mechanism of ovulatory follicle selection in sheep. J. Reprod. Fertil. 1999. doi:10.1530/jrf.0.1170355.

36. Viñoles C, Forsberg M, Martin GB, Cajaraville C, Repetto J, Meikle A. Short-term nutritional supplementation of ewes in low body condition affects follicle development due to an increase in glucose and metabolic hormones. Reproduction 2005. doi:10.1530/rep.1.00536.

37. Murdoch WJ, Peterson T a, Van Kirk E a, Vincent DL, Inskeep EK. Interactive roles of progesterone, prostaglandins, and collagenase in the ovulatory mechanism of the ewe. Biol. Reprod. 1986. doi:10.1095/biolreprod35.5.1187.

38. Murdoch WJ, Van Kirk EA, Murdoch J. Plasmin cleaves tumor necrosis factor alpha exodomain from sheep follicular endothelium: implication in the ovulatory process. Biol Reprod 1999. doi:10.1095/biolreprod60.5.1166.

39. Colgin DC, Murdoch WJ. Evidence for a role of the ovarian surface epithelium in the ovulatory mechanism of the sheep: Secretion of urokinase-type plasminogen activator. Anim. Reprod. Sci. 1997. doi:10.1016/S0378-4320(97)00011-0.

40. Niswender G, Davis T, Griffith R, Bogan R, Monser K, Bott R, Bruemmer J, Nett T. Judge, jury and executioner: the auto-regulation of luteal function. Reprod. Domest. Ruminants 2007. doi:10.5661/RDR-VI-191.

41. Bogan RL, Niswender GD. Constitutive Steroidogenesis in Ovine Large Luteal Cells May Be Mediated by Tonically Active Protein Kinase A. Biol. Reprod. 2007. doi:10.1095/biolreprod.106.059618.

42. Juengel JL, Nett TM, Anthony R V, Niswender GD. Effects of luteotrophic and luteolytic hormones on expression of mRNA encoding insulin-like growth factor I and growth hormone receptor in the ovine corpus luteum. J. Reprod. Fertil. 1997. doi:10.1530/jrf.0.1100291.

43. Goodman RL. Neuroendocrine Control of Gonadotropin Secretion: Comparative Aspects. In: Knobil and Neill's Physiology of Reproduction.; 2015:1537-1574.

44. Fitz TA, Mock EJ, Mayan MH, Niswender GD. Interactions of prostaglandins with subpopulations of ovine luteal cells. II. Inhibitory effects of PGF2 $\alpha$ and protection by PGE2. Prostaglandins 1984. doi:10.1016/0090-6980(84)90120-5.

45. Schramm W, Bovaird L, Glew ME, Schramm G, McCracken JA. Corpus luteum regression induced by ultra-low pulses of prostaglandin F2 $\alpha$. Prostaglandins 1983. doi:10.1016/0090-6980(83)90171-5.

46. Sawyer HR, Niswender KD, Braden TD, Niswender GD. Nuclear changes in ovine luteal cells in response to PGF2 $\alpha$. Domest. Anim. Endocrinol. 1990. doi:10.1016/07397240(90)90029-Y.

47. Tsai SJ, Wiltbank MC. Prostaglandin F2alpha induces expression of prostaglandin G/H synthase- 2 in the ovine corpus luteum: a potential positive feedback loop during luteolysis. Biol. Reprod. 1997;57(5):1016-1022. 
48. Lehman MN, Robinson JE, Karsch FJ, Silverman A -J. Immunocytochemical localization of luteinizing hormone-releasing hormone (LHRH) pathways in the sheep brain during anestrus and the mid-luteal phase of the estrous cycle. J. Comp. Neurol. 1986;244(1):19-35.

49. Lehman MN, Karsch FJ. Do gonadotropin-releasing hormone, tyrosine hydroxylase-, and $\beta$-endorphin-immunoreactive neurons contain estrogen receptors? A double-label immunocytochemical study in the suffolk ewe. Endocrinology 1993;133(2):887-895.

50. Skinner DC, Herbison a E. Effects of photoperiod on estrogen receptor, tyrosine hydroxylase, neuropeptide Y, and beta-endorphin immunoreactivity in the ewe hypothalamus. Endocrinology 1997;138(6):2585-2595.

51. Herbison AE, Robinson JE, Skinner DC. Distribution of estrogen receptorimmunoreactive cells in the preoptic area of the ewe: Co-localization with glutamic acid decarboxylase but not luteinizing hormone-releasing hormone. Neuroendocrinology 1993;57(4):751-759.

52. Pompolo S, Pereira A, Scott CJ, Fujiyma F, Clarke IJ. Evidence for estrogenic regulation of gonadotropin-releasing hormone neurons by glutamatergic neurons in the ewe brain: An immunohistochemical study using an antibody against vesicular glutamate transporter-2. J. Comp. Neurol. 2003;465(1):136-144.

53. Scott CJ, Rawson JA, Pereira AM, Clarke IJ. Oestrogen receptors in the brainstem of the female sheep: Relationship to noradrenergic cells and cells projecting to the medial preoptic area. J. Neuroendocrinol. 1999;11(10):745-756.

54. Simonian SX, Delaleu B, Caraty A, Herbison AE. Estrogen receptor expression in brainstem noradrenergic neurons of the sheep. Neuroendocrinology 1998;67(6):392-402.

55. Goodman RL, Lehman MN. Kisspeptin neurons from mice to men: Similarities and differences. Endocrinology 2012;153(11):5105-5118.

56. Tillet Y, Tourlet S, Picard S, Sizaret PY, Caraty A. Morphofunctional interactions between galanin and GnRH-containing neurones in the diencephalon of the ewe. The effect of oestradiol. J. Chem. Neuroanat. 2012;43(1):14-19.

57. Foradori CD, Amstalden M, Coolen LM, Singh SR, McManus CJ, Handa RJ, Goodman RL, Lehman MN. Orphanin FQ: Evidence for a role in the control of the reproductive neuroendocrine system. Endocrinology 2007;148(10):4993-5001.

58. Smith JT, Clarke IJ. Gonadotropin inhibitory hormone function in mammals. Trends Endocrinol. Metab. 2010;21(4):255-260.

59. Foradori CD, Coolen LM, Fitzgerald ME, Skinner DC, Goodman RL, Lehman MN. Colocalization of progesterone receptors in parvicellular dynorphin neurons of the ovine preoptic area and hypothalamus. Endocrinology 2002;143(11):4366-4374.

60. Goubillon ML, Forsdike RA, Robinson JE, Ciofi P, Caraty A, Herbison AE. Identification of neurokinin B-expressing neurons as an highly estrogen-receptive, sexually dimorphic cell group in the ovine arcuate nucleus. Endocrinology 2000;141(11):4218-4225.

61. Scanlan N, Dufourny L, Skinner DC. Somatostatin-14 neurons in the ovine hypothalamus: colocalization with estrogen receptor alpha and somatostatin-28(1-12) immunoreactivity, and activation in response to estradiol. Biol. Reprod. 2003;69(4):131824.

62. Goodman RL, Lehman MN, Smith JT, Coolen LM, De Oliveira CVR, Jafarzadehshirazi MR, Pereira A, Iqbal J, Caraty A, Ciofi P, Clarke IJ. Kisspeptin 
neurons in the arcuate nucleus of the ewe express both dynorphin A and neurokinin B. Endocrinology 2007. doi:10.1210/en.2007-0961.

63. Goodman RL, Hileman SM, Nestor CC, Porter KL, Connors JM, Hardy SL, Millar RP, Cernea M, Coolen LM, Lehman MN. Kisspeptin, neurokinin B, and dynorphin act in the arcuate nucleus to control activity of the GnRH pulse generator in ewes. Endocrinology 2013;154(11):4259-4269.

64. Lehman MN, Coolen LM, Goodman RL. Minireview: Kisspeptin/neurokinin B/dynorphin (KNDy) cells of the arcuate nucleus: A central node in the control of gonadotropin-releasing hormone secretion. Endocrinology 2010;151(8):3479-3489.

65. Bedenbaugh MN, D 'oliveira M, Cardoso RC, Hileman SM, Williams GL, Amstalden M. Pubertal escape from estradiol negative feedback in ewe lambs is not accounted for by decreased ESR1 mRNA or protein in kisspeptin neurons. Endocrinol. Copyr. 2017. doi:10.1210/en.2017-00593.

66. Merkley CM, Coolen LM, Goodman RL, Lehman MN. Evidence for Changes in Numbers of Synaptic Inputs onto KNDy and GnRH Neurones during the Preovulatory LH Surge in the Ewe. J. Neuroendocrinol. 2015;27(7):624-35.

67. Messager S, Chatzidaki EE, Ma D, Hendrick AG, Zahn D, Dixon J, Thresher RR, Malinge I, Lomet D, Carlton MBL, Colledge WH, Caraty A, Aparicio S a JR. Kisspeptin directly stimulates gonadotropin-releasing hormone release via $\mathrm{G}$ proteincoupled receptor 54. Proc. Natl. Acad. Sci. U. S. A. 2005;102(5):1761-1766.

68. Redmond JS, Macedo GG, Velez IC, Caraty a., LWilliams G, Amstalden M. Kisspeptin activates the hypothalamic-adenohypophyseal-gonadal axis in prepubertal ewe lambs. Reproduction 2011;141(4):541-548.

69. Billings HJ, Connors JM, Altman SN, Hileman SM, Holaskova I, Lehman MN, McManus CJ, Nestor CC, Jacobs BH, Goodman RL. Neurokinin B acts via the neurokinin-3 receptor in the retrochiasmatic area to stimulate luteinizing hormone secretion in sheep. Endocrinology 2010;151(8):3836-3846.

70. Porter KL, Hileman SM, Hardy SL, Nestor CC, Lehman MN, Goodman RL. Neurokinin-3 Receptor Activation in the Retrochiasmatic Area is Essential for the Full Preovulatory LH Surge in Ewes. J. Neuroendocrinol. 2014. doi:10.1111/jne.12180.

71. Goodman RL, Coolen LM, Anderson GM, Hardy SL, Valent M, Connors JM, Fitzgerald ME, Lehman MN. Evidence that dynorphin plays a major role in mediating progesterone negative feedback on gonadotropin-releasing hormone neurons in sheep. Endocrinology 2004;145(6):2959-2967.

72. Lopez JA, Bedenbaugh MN, McCosh RB, Weems PW, Meadows LJ, Wisman B, Coolen LM, Goodman RL, Hileman SM. Does Dynorphin Play a Role in the Onset of Puberty in Female Sheep? J. Neuroendocrinol. 2016. doi:10.1111/jne.12445.

73. Tourlet S, Ziyazetdinova G, Caraty A, Tramu G, Delsol G, Tillet Y. Oestradiol effect on galanin-immunoreactive neurones in the diencephalon of the ewe. J. Neuroendocrinol. 2005;17(3):145-151.

74. Whitelaw CM, Robinson JE, Hastie PM, Padmanabhan V, Evans NP. Effects of cycle stage on regionalised galanin, galanin receptors 1-3, GNRH and GNRH receptor mrna expression in the ovine hypothalamus. J. Endocrinol. 2012;212(3):353-361.

75. Dufourny L, Skinner DC. Distribution of galanin receptor 1-immunoreactive neurons in the ovine hypothalamus: Colocalization with GnRH. Brain Res. 2005;1054(1):73-81.

76. Lee JH, Miele ME, Hicks DJ, Phillips KK, Trent JM, Weissman BE, Welch DR. 
KiSS-1, a novel human malignant melanoma metastasis-suppressor gene. J. Natl. Cancer Inst. 1996. doi:10.1093/jnci/88.23.1731.

77. Kotani M, Detheux M, Vandenbogaerde A, Communi D, Vanderwinden JM, Le Poul E, Brézillon S, Tyldesley R, Suarez-Huerta N, Vandeput F, Blanpain C, Schiffmann SN, Vassart G, Parmentier M. The Metastasis Suppressor Gene KiSS-1 Encodes Kisspeptins, the Natural Ligands of the Orphan G Protein-coupled Receptor GPR54. J. Biol. Chem. 2001;276(37):34631-34636.

78. Ohtaki T, Shintani Y, Honda S, Matsumoto H, Hori a, Kanehashi K, Terao Y, Kumano S, Takatsu Y, Masuda Y, Ishibashi Y, Watanabe T, Asada M, Yamada T, Suenaga M, Kitada C, Usuki S, Kurokawa T, Onda H, Nishimura O, Fujino M. Metastasis suppressor gene KiSS-1 encodes peptide ligand of a G-protein-coupled receptor. Nature 2001;411(6837):613-617.

79. Clements MK, McDonald TP, Wang R, Xie G, O'Dowd BF, George SR, Austin CP, Liu Q. FMRFamide-related neuropeptides are agonists of the orphan G-protein-coupled receptor GPR54. Biochem. Biophys. Res. Commun. 2001. doi:10.1006/bbrc.2001.5098.

80. Muir a I, Chamberlain L, Elshourbagy N a, Michalovich D, Moore DJ, Calamari a, Szekeres PG, Sarau HM, Chambers JK, Murdock P, Steplewski K, Shabon U, Miller JE, Middleton SE, Darker JG, Larminie CG, Wilson S, Bergsma DJ, Emson P, Faull R, Philpott KL, Harrison DC, Axor12. a novel human G protein-coupled receptor, activated by the peptide. KiSS-1, J. Biol. Chem. 2001;276:28969-28975.

81. Seminara SB, Messager S, Chatzidaki EE, Thresher RR, Acierno JS, Shagoury JK, Bo-Abbas Y, Kuohung W, Schwinof KM, Hendrick AG, Zahn D, Dixon J, Kaiser UB, Slaugenhaupt S a, Gusella JF, O'Rahilly S, Carlton MBL, Crowley WF, Aparicio S a JR, Colledge WH. The GPR54 gene as a regulator of puberty. N. Engl. J. Med. 2003;349(17):1614-1627.

82. de Roux N, Genin E, Carel J-C, Matsuda F, Chaussain J-L, Milgrom E. Hypogonadotropic hypogonadism due to loss of function of the KiSS1-derived peptide receptor GPR54. Proc. Natl. Acad. Sci. U. S. A. 2003;100(19):10972-10976.

83. Funes S, Hedrick JA, Vassileva G, Markowitz L, Abbondanzo S, Golovko A, Yang S, Monsma FJ, Gustafson EL. The KiSS-1 receptor GPR54 is essential for the development of the murine reproductive system. Biochem. Biophys. Res. Commun. 2003. doi:10.1016/j.bbrc.2003.11.066.

84. d'Anglemont de Tassigny X, Fagg LA, Dixon JPC, Day K, Leitch HG, Hendrick AG, Zahn D, Franceschini I, Caraty A, Carlton MBL, Aparicio SAJR, Colledge WH. Hypogonadotropic hypogonadism in mice lacking a functional Kiss1 gene. Proc. Natl. Acad. Sci. 2007. doi:10.1073/pnas.0704114104.

85. Franceschini I, Lomet D, Cateau M, Delsol G, Tillet Y, Caraty A. Kisspeptin immunoreactive cells of the ovine preoptic area and arcuate nucleus co-express estrogen receptor alpha. Neurosci. Lett. 2006;401(3):225-230.

86. Tena-Sempere M, Kauffman a. S, Roa J, Navarro VM, Gottsch ML, Clifton DK, Steiner R a. Sexual differentiation of Kiss1 expression in the brain of the rat. Front. Neuroendocrinol. 2006;27(1):97.

87. Clarkson J, Herbison AE. Postnatal development of kisspeptin neurons in mouse hypothalamus; sexual dimorphism and projections to gonadotropin-releasing hormone neurons. Endocrinology 2006;147(12):5817-5825.

88. Smith JT, Clay CM, Caraty A, Clarke IJ. KiSS-1 messenger ribonucleic acid 
expression in the hypothalamus of the ewe is regulated by sex steroids and season. Endocrinology 2007. doi:10.1210/en.2006-1435.

89. Merkley CM, Porter KL, Coolen LM, Hileman SM, Billings HJ, Drews S, Goodman RL, Lehman MN. KNDy (kisspeptin/neurokinin B/dynorphin) neurons are activated during both pulsatile and surge secretion of LH in the ewe. Endocrinology 2012;153(11):5406-5414.

90. Navarro VM, Ruiz-Pino F, Sanchez-Garrido MA, Garcia-Galiano D, Hobbs SJ, Manfredi-Lozano M, Leon S, Sangiao-Alvarellos S, Castellano JM, Clifton DK, Pinilla L, Steiner RA, Tena-Sempere M. Role of Neurokinin B in the Control of Female Puberty and Its Modulation by Metabolic Status. J. Neurosci. 2012. doi:10.1523/JNEUROSCI.4288-11.2012.

91. Rance NE, Young WS. Hypertrophy and increased gene expression of neurons containing neurokinin-b and substance-p messenger ribonucleic acids in the hypothalami of postmenopausal women. Endocrinology 1991. doi:10.1210/endo-128-5-2239.

92. Lucas LR, Hurley DL, Krause JE, Harlan RE. Localization of the tachykinin neurokinin B precursor peptide in rat brain by immunocytochemistry and in situ hybridization. Neuroscience 1992. doi:10.1016/0306-4522(92)90318-V.

93. Amstalden M, Coolen LM, Hemmerle AM, Billings HJ, Connors JM, Goodman RL, Lehman MN. Neurokinin 3 receptor immunoreactivity in the septal region, preoptic area and hypothalamus of the female sheep: Colocalisation in neurokinin B cells of the arcuate nucleus but not in gonadotrophin-releasing hormone neurones. J. Neuroendocrinol. 2010;22(1):1-12.

94. Mileusnic D, Lee JM, Magnuson DJ, Hejna MJ, Krause JE, Lorens JB, Lorens SA. Neurokinin-3 receptor distribution in rat and human brain: An immunohistochemical study. Neuroscience 1999. doi:10.1016/S0306-4522(98)00349-2.

95. Yip J, Chahl LA. Localization of NK1and NK3receptors in guinea-pig brain. Regul. Pept. 2001. doi:10.1016/S0167-0115(00)00228-7.

96. Topaloglu a K, Reimann F, Guclu M, Yalin AS, Kotan LD, Porter KM, Serin A, Mungan NO, Cook JR, Ozbek MN, Imamoglu S, Akalin NS, Yuksel B, O'Rahilly S, Semple RK. TAC3 and TACR3 mutations in familial hypogonadotropic hypogonadism reveal a key role for Neurokinin B in the central control of reproduction. Nat. Genet. 2009;41(3):354-358.

97. Fergani C, Mazzella L, Coolen LM, McCosh RB, Hardy SL, Newcomb N, Grachev P, Lehman MN, Goodman RL. Do substance $p$ and neurokinin a play important roles in the control of lh secretion in ewes? Endocrinology 2016. doi:10.1210/en.2016-1565.

98. Sillard R, Langel Ü, Jörnvall H. Isolation and characterization of galanin from sheep brain. Peptides 1991. doi:10.1016/0196-9781(91)90146-G.

99. Skofitsch G, Jacobowitz DM. Immunohistochemical mapping of galanin-like neurons in the rat central nervous system. Peptides 1985. doi:10.1016/0196-9781(85)90118-4.

100. Kordower JH, Le HK, Mufson EJ. Galanin immunoreactivity in the primate central nervous system. J. Comp. Neurol. 1992. doi:10.1002/cne.903190403.

101. Pearson PL, Anderson LL, Jacobson CD. The prepubertal ontogeny of luteinizing hormone releasing hormone-like immunoreactivity in the diencephalon and telencephalon of the male Meishan pig brain. Dev. Brain Res. 1996. doi:10.1016/0165-3806(96)00083-1.

102. Chaillou E, Tramu G, Tillet Y. Distribution of galanin immunoreactivity in the sheep diencephalon. J. Chem. Neuroanat. 1999. doi:10.1016/S0891-0618(99)00032-0. 
103. MELANDER T, FUXE K, HÄRFSTRAND A, ENEROTH P, HÖKFELT T. Effects of intraventricular injections of galanin on neuroendocrine functions in the male rat. Possible involvement of hypothalamic catecholamine neuronal systems. Acta Physiol. Scand. 1987. doi:10.1111/j.1748-1716.1987.tb08201.x.

104. Arvat E, Gianotti L, Ramunni J, Grottoli S, Brossa PC, Bertagna A, Camanni F, Ghigo E. Effect of galanin on basal and stimulated secretion of prolactin, gonadotropins, thyrotropin, adrenocorticotropin and cortisol in humans. Eur. J. Endocrinol. 1995. doi:10.1530/eje.0.1330300.

105. Spencer GSG, Berry CJ, Bass JJ. Neuroendocrine regulation of growth hormone secretion in sheep. VII. Effects of GABA. Regul. Pept. 1994. doi:10.1016/01670115(94)90052-3.

106. Coen CW, Montagnese C, Opacka-Juffry J. Coexistence of Gonadotrophin-Releasing Hormone and Galanin: Immunohisto-chemical and Functional Studies. $J$. Neuroendocrinol. 1990. doi:10.1111/j.1365-2826.1990.tb00839.x.

107. Merchenthaler I, Lopez FJ, Negro-Vilar A. Colocalization of galanin and luteinizing hormone-releasing hormone in a subset of preoptic hypothalamic neurons: anatomical and functional correlates. Proc. Natl. Acad. Sci. 1990. doi:10.1073/pnas.87.16.6326.

108. Finn PD, Pau KYF, Spies HG, Cunningham MJ, Clifton DK, Steiner RA. Galanin's functional significance in the regulation of the neuroendocrine reproductive axis of the monkey. Neuroendocrinology 2000. doi:10.1159/000054516.

109. Merchenthaler I, López FJ, Lennard DE, Negro-Vilar A. Sexual differences in the distribution of neurons coexpressing galanin and luteinizing hormone-releasing hormone in the rat brain. Endocrinology 1991. doi:10.1210/endo-129-4-1977.

110. Liposits Z, Reid JJ, Negro-Vilar A, Merchenthaler I. Sexual dimorphism in copackaging of luteinizing hormone-releasing hormone and galanin into neurosecretory vesicles of hypophysiotrophic neurons: Estrogen dependency. Endocrinology 1995. doi:10.1210/endo.136.5.7536660.

111. Mitchell V, Bouret S, Prévot V, Jennes L, Beauvillain JC. Evidence for expression of galanin receptor Gal-R1 mRNA in certain gonadotropin releasing hormone neurones of the rostral preoptic area. J. Neuroendocrinol. 1999. doi:10.1046/j.13652826.1999.00399.x.

112. Rajendren G, Li X. Galanin synaptic input to gonadotropin-releasing hormone perikarya in juvenile and adult female mice: implications for sexual maturity. Brain Res. Dev. Brain Res. 2001.

113. Dudás B, Merchenthaler I. Bi-directional associations between galanin and luteinizing hormone-releasing hormone neuronal systems in the human diencephalon. Neuroscience 2004. doi:10.1016/j.neuroscience.2004.05.018.

114. López FJ, Merchenthaler I, Ching M, Wisniewski MG, Negro-Vilar A. Galanin: a hypothalamic-hypophysiotropic hormone modulating reproductive functions. Proc. Natl. Acad. Sci. U. S. A. 1991. doi:10.1073/pnas.88.10.4508.

115. Hrabovszky E, Vrontakis ME, Petersen SL. Triple-labeling method combining immunocytochemistry and in situ hybridization histochemistry: Demonstration of overlap between Fos- immunoreactive and galanin mRNA-expressing subpopulations of luteinizing hormone-releasing hormone neurons in female rats. J. Histochem. Cytochem. 1995. doi: $10.1177 / 43.4 .7534782$.

116. Sahu A, Crowley WR, Tatemoto K, Balasubramaniam A, Kalra SP. Effects of 
neuropeptide Y, NPY analog (norleucine4-NPY), galanin and neuropeptide K on LH release in ovariectomized (ovx) and ovx estrogen, progesterone-treated rats. Peptides 1987. doi:10.1016/0196-9781(87)90081-7.

117. Dufourny L, Schofield N, Skinner DC. Immunoreactive galanin expression in ovine gonadotropin-releasing hormone neurones: No effects of gender or reproductive status. $J$. Neuroendocrinol. 2003;15(11):1062-1069.

118. Chambers G, Whitelaw CM, Robinson JE, Evans NP. Distribution of galanin receptor2 immunoreactive neurones in the ovine hypothalamus: No evidence for involvement in the control of gonadotrophin-releasing hormone secretion. J. Neuroendocrinol. 2007. doi:10.1111/j.1365-2826.2007.01609.x.

119. Weems PW, Witty CF, Amstalden M, Coolen LM, Goodman RL, Lehman MN. Kappa Opioid Receptor is Co-localized in GnRH and KNDy Cells in the Female Ovine and Rat Brain. Endocrinology 2016:en-2015.

120. Foradori CD, Amstalden M, Goodman RL, Lehman MN. Colocalisation of dynorphin A and neurokinin B immunoreactivity in the arcuate nucleus and median eminence of the sheep. J. Neuroendocrinol. 2006;18(7):534-541.

121. Smith JT, Li Q, Pereira a., Clarke IJ. Kisspeptin neurons in the ovine arcuate nucleus and preoptic area are involved in the preovulatory luteinizing hormone surge. Endocrinology 2009;150(12):5530-5538.

122. Nestor CC, Bedenbaugh MN, Hileman SM, Coolen LM, Lehman MN, Goodman RL. Regulation of GnRH pulsatility in sheep. Reproduction 2018;2:REP-18-0127.

123. Oakley AE, Clifton DK, Steiner RA. Kisspeptin signaling in the brain. Endocr. Rev. 2009. doi:10.1210/er.2009-0005.

124. Rometo AM, Krajewski SJ, Voytko M Lou, Rance NE. Hypertrophy and increased kisspeptin gene expression in the hypothalamic infundibular nucleus of postmenopausal women and ovariectomized monkeys. J. Clin. Endocrinol. Metab. 2007;92(7):2744-2750.

125. Couse JF, Yates MM, Walker VR, Korach KS. Characterization of the HypothalamicPituitary-Gonadal Axis in Estrogen Receptor (ER) Null Mice Reveals Hypergonadism and Endocrine Sex Reversal in Females Lacking ER $\alpha$ But Not ER $\beta$. Mol. Endocrinol. 2003. doi:10.1210/me.2002-0398.

126. Gottsch ML, Navarro VM, Zhao Z, Glidewell-Kenney C, Weiss J, Jameson JL, Clifton DK, Levine JE, Steiner R a. Regulation of Kiss1 and dynorphin gene expression in the murine brain by classical and nonclassical estrogen receptor pathways. J. Neurosci. 2009;29(29):9390-9395.

127. Kim WR, Jessen HM, Auger AP, Terasawa E. Postmenopausal increase in KiSS-1, GPR54, and luteinizing hormone releasing hormone (LHRH-1) mRNA in the basal hypothalamus of female rhesus monkeys. Peptides 2009. doi:10.1016/j.peptides.2008.06.005.

128. Redmond JS, Baez-Sandoval GM, Spell KM, Spencer TE, Lents C a., Williams GL, Amstalden M. Developmental Changes in Hypothalamic Kiss1 Expression during Activation of the Pulsatile Release of Luteinising Hormone in Maturing Ewe Lambs. $J$. Neuroendocrinol. 2011;23(9):815-822.

129. Navarro VM, Castellano JM, Fernández-Fernández R, Barreiro ML, Roa J, Sanchez-Criado JE, Aguilar E, Dieguez C, Pinilla L, Tena-Sempere M.

Developmental and hormonally regulated messenger ribonucleic acid expression of KiSS1 and its putative receptor, GPR54, in rat hypothalamus and potent luteinizing hormone- 
releasing activity of KiSS-1 peptide. Endocrinology 2004;145(10):4565-4574.

130. Goodman RL, Holaskova I, Nestor CC, Connors JM, Billings HJ, Valent M, Lehman MN, Hileman SM. Evidence that the arcuate nucleus is an important site of progesterone negative feedback in the ewe. Endocrinology 2011. doi:10.1210/en.2011-0195.

131. Ferin M, Vande Wiele R. Endogenous opioid peptides and the control of the menstrual cycle. Eur. J. Obstet. Gynecol. Reprod. Biol. 1984. doi:10.1016/0028-2243(84)90059-5.

132. Foradori CD, Goodman RL, Lehman MN. Distribution of preprodynorphin mRNA and dynorphin-A immunoreactivity in the sheep preoptic area and hypothalamus.

Neuroscience 2005;130(2):409-418.

133. Caraty a., Fabre-Nys C, Delaleu B, Locatelli a., Bruneau G, Karsch FJ, Herbison a. Evidence that the mediobasal hypothalamus is the primary site of action of estradiol in inducing the preovulatory gonadotropin releasing hormone surge in the ewe. Endocrinology 1998;139(4):1752-1760.

134. Moenter SM, Karsch FJ, Lehman MN. Fos expression during the estradiol-induced gonadotropin-releasing hormone (Gnrh) surge of the ewe: Induction in gnrh and other neurons. Endocrinology 1993;133(2):896-903.

135. Pau KF, Kuehl DE, Jackson GL. Effect of frontal hypothalamic deafferentation on luteinizing hormone secretion and seasonal breeding in the ewe. Biol. Reprod. 1982;27(June):999-1009.

136. Evans NP, Richter TA, Skinner DC, Robinson JE. Neuroendocrine mechanisms underlying the effects of progesterone on the oestradiol-induced GnRH/LH surge. Reprod Suppl 2002;59:57-66.

137. Anderson ST, Walsh JP, Tillet Y, Clarke IJ, Curlewis JD. Dopaminergic input to the ventromedial hypothalamus facilitates the oestrogen-induced luteinizing hormone surge in ewes. Neuroendocrinology 2001;73(2):91-101.

138. Pillon D, Caraty A, Fabre-Nys C, Lomet D, Cateau M, Bruneau G. Regulation by estradiol of hypothalamic somatostatin gene expression: possible involvement of somatostatin in the control of luteinizing hormone secretion in the ewe. Biol. Reprod. 2004;71(1):38-44.

139. Fergani C, Routly JE, Jones DN, Pickavance LC, Smith RF, Dobson H. Activation of Cells Containing Estrogen Receptor Alpha or Somatostatin in the Medial Preoptic Area, Arcuate Nucleus, and Ventromedial Nucleus of Intact Ewes During the Follicular Phase, and Alteration after Lipopolysaccharide1. Biol. Reprod. 2014;91(6):1-12.

140. McCosh RB, Szeligo BM, Bedenbaugh MN, Lopez JA, Hardy SL, Hileman SM, Lehman MN, Goodman RL. Evidence that endogenous somatostatin inhibits episodic, but not surge, secretion of LH in female sheep. Endocrinology 2017;158(6):1827-1837.

141. Pillon D, Caraty A, Fabre-Nys C, Bruneau G. Early decrease of proopiomelanocortin but not neuropeptide Y mRNA expression in the mediobasal hypothalamus of the ewe, during the estradiol-induced preovulatory LH surge. Gen. Comp. Endocrinol. 2003;134(3):264-272.

142. Conover CD, Kuljis RO, Rabii J, Advis JP. Beta-endorphin regulation of luteinizing hormone-releasing hormone release at the median eminence in ewes:

Immunocytochemical and physiological evidence. Neuroendocrinology 1993;57(6):11821195.

143. Christian CA, Moenter SM. The neurobiology of preovulatory and estradiol-induced gonadotropin- releasing hormone surges. Endocr. Rev. 2010;31(4):544-577. 
144. Currie WD, Joseph IB, Rawlings NC. Morphine, naloxone and the gonadotrophin surge in ewes. J Reprod Fertil 1991;92(2):407-414.

145. Walsh JP, Clarke IJ. Effects of central administration of highly selective opioid $\mu-, \delta$ and $\kappa$-receptor agonists on plasma luteinizing hormone ( $\mathrm{LH})$, prolactin, and the estrogeninduced LH surge in ovariectomized ewes. Endocrinology 1996;137(9):3640-3648.

146. Goubillon ML, Delaleu B, Tillet Y, Caraty A, Herbison AE. Localization of estrogenreceptive neurons projecting to the GnRH neuron-containing rostral preoptic area of the ewe. Neuroendocrinology 1999;70(4):228-236.

147. Rawson JA, Scott CJ, Pereira A, Jakubowska A, Clarke IJ. Noradrenergic projections from the A1 field to the preoptic area in the brain of the ewe and Fos responses to oestrogen in the A1 cells. J. Neuroendocrinol. 2001;13(2):129-138.

148. Clarke IJ, Scott CJ, Pereira A, Rawson J. Levels of dopamine $\beta$ hydroxylase immunoreactivity in the preoptic hypothalamus of the ovariectomised ewe following injection of oestrogen: Evidence for increased noradrenaline release around the time of the oestrogen-induced surge in luteinizing hormone. J. Neuroendocrinol. 1999;11(7):503512.

149. Goodman RL, Inskeep EK. Control of the Ovarian Cycle of the Sheep. In: Knobil and Neill's Physiology of Reproduction: Two-Volume Set.Vol 2.; 2014:1259-1305.

150. Clarke IJ, Scott CJ, Pereira A, Pompolo S. The role of noradrenaline in the generation of the preovulatory LH surge in the ewe. Domest. Anim. Endocrinol. 2006;30(4):260-275.

151. Smith JT, Li Q, Yap KS, Shahab M, Roseweir AK, Millar RP, Clarke IJ. Kisspeptin is essential for the full preovulatory LH surge and stimulates GnRH release from the isolated ovine median eminence. Endocrinology 2011;152(3):1001-1012.

152. Smith JT, Coolen LM, Kriegsfeld LJ, Sari IP, Jaafarzadehshirazi MR, Maltby M, Bateman K, Goodman RL, Tilbrook AJ, Ubuka T, Bentley GE, Clarke IJ, Lehman MN. Variation in kisspeptin and RFamide-related peptide (RFRP) expression and terminal connections to gonadotropin-releasing hormone neurons in the brain: A novel medium for seasonal breeding in the sheep. Endocrinology 2008;149(11):5770-5782.

153. Smith JT, Cunningham MJ, Rissman EF, Clifton DK, Steiner R a. Regulation of Kiss1 gene expression in the brain of the female mouse. Endocrinology 2005;146(9):3686-3692.

154. Smith JT, Li Q, Pereira A, Clarke IJ. Kisspeptin neurons in the ovine arcuate nucleus and preoptic area are involved in the preovulatory luteinizing hormone surge. Endocrinology 2009;150(12):5530-5538.

155. Hoffman GE, Le WW, Franceschini I, Caraty A, Advis JP. Expression of fos and in vivo median eminence release of LHRH identifies an active role for preoptic area kisspeptin neurons in synchronized surges of LH and LHRH in the ewe. Endocrinology 2011;152(1):214-222.

156. Smith JT, Coolen LM, Kriegsfeld LJ, Sari IP, Jaafarzadehshirazi MR, Maltby M, Bateman K, Goodman RL, Tilbrook AJ, Ubuka T, Bentley GE, Clarke IJ, Lehman MN. Variation in kisspeptin and RFamide-related peptide (RFRP) expression and terminal connections to gonadotropin-releasing hormone neurons in the brain: A novel medium for seasonal breeding in the sheep. Endocrinology 2008;149(11):5770-5782.

157. Smith JT. Sex steroid control of hypothalamic Kiss1 expression in sheep and rodents: Comparative aspects. Peptides 2009. doi:10.1016/j.peptides.2008.08.013.

158. Smith, M. F.; Hawken, P. A. R.; Lehman, M. N.; Martin GB. The role of kisspeptin in 
reproductive function in the ewe. Reprod. Domest. Ruminants 2014.

159. Smith JT, Cunningham MJ, Rissman EF, Clifton DK, Steiner RA. Regulation of Kiss 1 gene expression in the brain of the female mouse. Endocrinology 2005;146(9):3686-3692.

160. Grachev P, Porter KL, Coolen LM, McCosh RB, Connors JM, Hileman SM, Lehman MN, Goodman RL. Surge-Like Luteinising Hormone Secretion Induced by Retrochiasmatic Area NK3R Activation is Mediated Primarily by Arcuate Kisspeptin Neurones in the Ewe. J. Neuroendocrinol. 2016;28(6). doi:10.1111/jne.12393.

161. Wood RI, Foster DL. Sexual differentiation of reproductive neuroendocrine function in sheep. Rev. Reprod. 1998;3(2):130-140.

162. Clarkson J, Herbison AE. Hypothalamic control of the male neonatal testosterone surge. Philos. Trans. R. Soc. B Biol. Sci. 2016. doi:10.1098/rstb.2015.0115.

163. MacLusky NJ, Naftolin F. Sexual differentiation of the central nervous system. Science 1981. doi:10.1126/science.6163211.

164. Goy RW, McEwen BS. Sexually dimorphic behavior: Definition and the organizational hypothesis. In: Sex and the brain.; 2007.

165. Corbier P, Kerdelhue B, Picon R, Roffi J. Changes in Testicular Weight and Serum Gonadotropin and Testosterone Levels before, during, and after Birth in the Perinatal Rat. Endocrinology 1978;103(6):1985-1991.

166. Weisz J, Ward IL. Plasma testosterone and progesterone titers of pregnant rats, their male and female fetuses, and neonatal offspring. Endocrinology 1980;106(1):306-316.

167. Zambrano E, Guzmán C, Rodríguez-González GL, Durand-Carbajal M, Nathanielsz PW. Fetal programming of sexual development and reproductive function. Mol. Cell. Endocrinol. 2014;382(1):538-549.

168. Connolly PB, Resko JA. Prenatal testosterone differentiates brain regions controlling gonadotropin release in guinea pigs. Biol. Reprod. 1994;51:125-130.

169. Foster DL, Ryan KD. Endocrine mechanisms governing transition into adulthood: A marked decrease in inhibitory feedback action of estradiol on tonic secretion of luteinizing hormone in the lamb during puberty. Endocrinology 1979. doi:10.1210/endo-105-4-896.

170. Ebling FJ, Kushler RH, Foster DL. Pulsatile LH secretion during sexual maturation in the female sheep: photoperiodic regulation in the presence and absence of ovarian steroid feedback as determined in the same individual. Neuroendocrinology 1990;52(3):229-237.

171. Wood RI, Ebling FJP, I'Anson H, Bucholtz DC, Yellon SM, Foster DL. Prenatal androgens time neuroendocrine sexual maturation. Endocrinology 1991. doi:10.1210/endo-128-5-2457.

172. Kosut SS, Wood RI, Herbosa-Encarnación C, Foster DL. Prenatal androgens time neuroendocrine puberty in the sheep: Effect of testosterone dose. Endocrinology 1997. doi:10.1210/endo.138.3.4993.

173. Wood RI, Mehta V, Herbosa CG, Foster DL. Prenatal testosterone differentially masculinizes tonic and surge modes of luteinizing-hormone secretion in the developing sheep. Neuroendocrinology 1995. doi:10.1159/000127010.

174. Veiga-Lopez A, Astapova OI, Aizenberg EF, Lee JS, Padmanabhan V. Developmental Programming: Contribution of Prenatal Androgen and Estrogen to Estradiol Feedback Systems and Periovulatory Hormonal Dynamics in Sheep1. Biol. Reprod. 2009. doi:10.1095/biolreprod.108.074781.

175. Masek KS, Wood RI, Foster DL. Prenatal dihydrotestosterone differentially 
masculinizes tonic and surge modes of luteinizing hormone secretion in sheep.

Endocrinology 1999. doi:10.1210/endo.140.8.6913.

176. Salloum BA, Herkimer C, Lee JS, Veiga-Lopez A, Padmanabhan V. Developmental programming: Prenatal and postnatal contribution of androgens and insulin in the reprogramming of estradiol positive feedback disruptions in prenatal testosterone-treated sheep. Endocrinology 2012. doi:10.1210/en.2011-2074.

177. Birch RA, Padmanabhan V, Foster DL, Unsworth WP, Robinson JE. Prenatal programming of reproductive neuroendocrine function: Fetal androgen exposure produces progressive disruption of reproductive cycles in sheep. Endocrinology 2003;144(4):14261434.

178. Clarke IJ, Scaramuzzi RJ, Short R V. Ovulation in prenatally androgenized ewes. J. Endocrinol. 1977. doi:10.1677/joe.0.0730385.

179. Manikkam M, Steckler TL, Welch KB, Inskeep EK, Padmanabhan V. Fetal programming: Prenatal testosterone treatment leads to follicular persistence/luteal defects; partial restoration of ovarian function by cyclic progesterone treatment. Endocrinology 2006. doi:10.1210/en.2005-1338.

180. Jackson LM, Timmer KM, Foster DL. Sexual differentiation of the external genitalia and the timing of puberty in the presence of an antiandrogen in sheep. Endocrinology 2008;149(8):4200-4208.

181. Foster DL, Ebling FJP, Ebling AF, Vannerson LA, Bucholtz DC, Wood RI, Suttie JM, Fenner DE. Metabolic interfaces between growth and reproduction. I. Nutritional modulation of gonadotropin, prolactin, and growth hormone secretion in the growthlimited female lamb. Endocrinology 1989. doi:10.1210/endo-125-1-342.

182. Tsai H-W, Legan SJ. Loss of luteinizing hormone surges induced by chronic estradiol is associated with decreased activation of gonadotropin-releasing hormone neurons. Biol. Reprod. 2002. doi:10.1095/biolreprod66.4.1104.

183. Nanda AS, Ward WR, Dobson H. Lack of LH response to oestradiol treatment in cows with cystic ovarian disease and effect of progesterone treatment or manual rupture. Res. Vet. Sci. 1991. doi:10.1016/0034-5288(91)90011-C.

184. Kim SJ, Foster DL, Wood RI. Prenatal testosterone masculinizes synaptic input to gonadotropin-releasing hormone neurons in sheep. Biol. Reprod. 1999. doi:10.1095/biolreprod61.3.599.

185. Nestor CC, Briscoe AMS, Davis SM, Valent M, Goodman RL, Hileman SM. Evidence of a role for kisspeptin and neurokinin B in puberty of female sheep. Endocrinology 2012;153(6):2756-2765.

186. Cheng G, Coolen LM, Padmanabhan V, Goodman RL, Lehman MN. The kisspeptin/neurokinin B/dynorphin (KNDy) cell population of the arcuate nucleus: Sex differences and effects of prenatal testosterone in sheep. Endocrinology 2010;151(1):301311.

187. Ahn T, Fergani C, Coolen LM, Padmanabhan V, Lehman MN. Prenatal Testosterone Excess Decreases Neurokinin 3 Receptor Immunoreactivity within the Arcuate Nucleus KNDy Cell Population. J. Neuroendocrinol. 2015;27(2):100-110.

188. Levine JE. New concepts of the neuroendocrine regulation of gonadotropin surges in rats. Biol. Reprod. 1997;56(2):293-302.

189. Khan AR, Kauffman AS. The role of kisspeptin and RFamide-related peptide-3 neurones in the circadian-timed preovulatory luteinising hormone surge. J. Neuroendocrinol. 
2012;24(1):131-143.

190. Plant TM. A comparison of the neuroendocrine mechanisms underlying the initiation of the preovulatory LH surge in the human, Old World monkey and rodent. Front. Neuroendocrinol. 2012;33(2):160-168.

191. Clarke IJ. The preovulatory LH surge. A case of a neuroendocrine switch. Trends Endocrinol. Metab. 1995;6(7):241-247.

192. de Roux N, Genin E, Carel J-C, Matsuda F, Chaussain J-L, Milgrom E. Hypogonadotropic hypogonadism due to loss of function of the KiSS1-derived peptide receptor GPR54. Proc. Natl. Acad. Sci. 2003. doi:10.1073/pnas.1834399100.

193. Seminara SB, Messager S, Chatzidaki EE, Thresher RR, Acierno JS, Shagoury JK, Bo-Abbas Y, Kuohung W, Schwinof KM, Hendrick AG, Zahn D, Dixon J, Kaiser UB, Slaugenhaupt SA, Gusella JF, O'Rahilly S, Carlton MBL, Crowley WF, Aparicio SAJR, Colledge WH. The GPR54 Gene as a Regulator of Puberty. Obstet. Gynecol. Surv. 2004. doi:10.1097/00006254-200405000-00020.

194. Lehman MN, Hileman SM, Goodman RL. Neuroanatomy of the kisspeptin signaling system in mammals: Comparative and developmental aspects. Adv. Exp. Med. Biol. 2013;784:27-62.

195. Herbison AE. Estrogen positive feedback to gonadotropin-releasing hormone (GnRH) neurons in the rodent: The case for the rostral periventricular area of the third ventricle (RP3V). Brain Res. Rev. 2008;57(2):277-287.

196. Nestor CC, Briscoe AMS, Davis SM, Valent M, Goodman RL, Hileman SM. Evidence of a role for kisspeptin and neurokinin B in puberty of female sheep. Endocrinology 2012;153(6):2756-2765.

197. Wakabayashi Y, Nakada T, Murata K, Ohkura S, Mogi K, Navarro VM, Clifton DK, Mori Y, Tsukamura H, Maeda K-I, Steiner R a, Okamura H. Neurokinin B and dynorphin A in kisspeptin neurons of the arcuate nucleus participate in generation of periodic oscillation of neural activity driving pulsatile gonadotropin-releasing hormone secretion in the goat. J. Neurosci. 2010;30(8):3124-3132.

198. Navarro VM; Gottsch ML; Chavkin C; Okamura H; Clifton DK; Steiner RA. Regulation of Gonadotropin-Releasing Hormone Secretion by Kisspeptin / Dynorphin / Neurokinin B Neurons in the Arcuate Nucleus of the Mouse. J. Neurosci. 2009;29(38):11859-11866.

199. Foster DL, Padmanabhan V, Wood RI, Robinson JE. Sexual differentiation of the neuroendocrine control of gonadotrophin secretion: concepts derived from sheep models. Reprod. Suppl. 2002;59:83-99.

200. Cheng G. Coolen LM. Padmanabhan V. Goodman RL. Lehman M. The kisspeptin/neurokinin B/dynorphin (KNDy) cell population of the arcuate nucleus: sex differences and effects of prenatal. Endocrinology 2010;151(1):301-311.

201. Robinson JE, Forsdike RA, Taylor JA. In utero exposure of female lambs to testosterone reduces the sensitivity of the gonadotropin-releasing hormone neuronal network to inhibition by progesterone. Endocrinology 1999;140(12):5797-5805.

202. Jackson LM, Mytinger A, Roberts EK, Lee TM, Foster DL, Padmanabhan V, Jansen HT. Developmental programming: Postnatal steroids complete prenatal steroid actions to differentially organize the $\mathrm{GnRH}$ surge mechanism and reproductive behavior in female sheep. Endocrinology 2013;154(4):1612-1623.

203. Anderson GM, Connors JM, Hardy SL, Valent M, Goodman RL. Oestradiol 
microimplants in the ventromedial preoptic area inhibit secretion of luteinizing hormone via dopamine neurones in anoestrous ewes. J. Neuroendocrinol. 2001;13(12):1051-1058.

204. Skinner DC, Harris TG, Evans NP. Duration and amplitude of the luteal phase progesterone increment times the estradiol-induced luteinizing hormone surge in ewes. Biol. Reprod. 2000;63(4):1135-42.

205. Watson RE, Wiegand SJ, Clough RW, Hoffman GE. Use of cryoprotectant to maintain long-term peptide immunoreactivity and tissue morphology. Peptides 1986;7(1):155-159.

206. Clarkson J, d'Anglemont de Tassigny X, Colledge WH, Caraty A, Herbison AE. Distribution of kisspeptin neurones in the adult female mouse brain. J. Neuroendocrinol. 2009. doi:10.1111/j.1365-2826.2009.01892.x.

207. Rajendren G. Increased galanin synapses onto activated gonadotropin-releasing hormone neuronal cell bodies in normal female mice and in functional preoptic area grafts in hypogonadal mice. J. Neuroendocrinol. 2002. doi:10.1046/j.1365-2826.2002.00796.x.

208. Gottsch ML, Zeng HK, Hohmann JG, Weinshenker D, Clifton DK, Steiner RA. Phenotypic analysis of mice deficient in the type 2 galanin receptor (GALR2). Mol. Cell. Biol. 2005. doi:25/11/4804 [pii] \r10.1128/MCB.25.11.4804-4811.2005.

209. Hohmann JG, Teklemichael DN, Weinshenker D, Wynick D, Clifton DK, Steiner RA. Obesity and endocrine dysfunction in mice with deletions of both neuropeptide $\mathrm{Y}$ and galanin. Mol. Cell. Biol. 2004. doi:10.1016/j.fct.2013.05.039.

210. Wynick D, Small CJ, Bacon A, Holmes FE, Norman M, Ormandy CJ, Kilic E, Kerr NCH, Ghatei M, Talamantes F, Bloom SR, Pachnis V. Galanin regulates prolactin release and lactotroph proliferation. Proc. Natl. Acad. Sci. 1998. doi:10.1073/pnas.95.21.12671.

211. Sahu A, Xu B, Kalra SP. Role of galanin in stimulation of pituitary luteinizing hormone secretion as revealed by a specific receptor antagonist, galantide. Endocrinology 1994. doi:10.1210/endo.134.2.7507825.

212. Foradori CD, Goodman RL, Adams VL, Valent M, Lehman MN. Progesterone increases dynorphin A concentrations in cerebrospinal fluid, and preprodynorphin messenger ribonucleic acid levels in a subset of dynorphin neurons in the sheep. Endocrinology 2005;146(4):1835-1842.

213. Hileman SM, McManus CJ, Goodman RL, Jansen HT. Neurons of the lateral preoptic area/rostral anterior hypothalamic area are required for photoperiodic inhibition of estrous cyclicity in sheep. Biol. Reprod. 2011. doi:10.1095/biolreprod.111.092031.

214. Pandit MA, Saxena RN. Galanin regulation of lh release in male rats. Indian J. Exp. Biol. 2010. doi:10.1097/01.ASW.0000433001.92396.b5.

215. Deaver DR, Stilley NJ, Dailey RA, Inskeep EK, Lewis PE. Concentrations of ovarian and pituitary hormones following prostaglandin F2 alpha-induced luteal regression in ewes varies with day of the estrous cycle at treatment. J. Anim. Sci. 1986. doi:10.2527/jas1986.622422x.

216. Goodman RL, Karsch FJ. Pulsatile secretion of luteinizing hormone: Differential suppression by ovarian steroids. Endocrinology 1980;107(5):1286-1290.

217. Rajendren G, Gibson MJ. Expression of galanin immunoreactivity in gonadotropinreleasing hormone neurons in mice: A confocal microscopic study. Brain Res. 1999. doi:10.1111/j.1525-1594.2011.01363.x.

218. Smith JT, Li Q, Yap KS, Shahab M, Roseweir AK, Millar RP, Clarke IJ. Kisspeptin is essential for the full preovulatory LH surge and stimulates GnRH release from the 
isolated ovine median eminence. Endocrinology 2011;152(3):1001-1012. 
Morphological and Functional Evidence of Sexual Dimorphism in the Retrochiasmatic Area Population of NK3R-containing Neurons in Sheep

\section{CHAPTER II}

Morphological and Functional Evidence for Sexual Dimorphism in the Retrochiasmatic Area Population of NK3R-Containing Neurons 
Morphological and Functional Evidence for Sexual Dimorphism in Neurokinin B Signaling in the Retrochiasmatic Area of Sheep

Justin A. Lopez, Richard B. McCosh, Michelle N. Bedenbaugh, Ashley N. Lindo, Elizabeth C.

Bowdridge, Stanley M. Hileman, Robert L. Goodman

Department of Physiology and Pharmacology, West Virginia University, Morgantown, WV

Abbreviated Title: Sexual Dimorphism in the Ovine Retrochiasmatic Area

Key Terms: GnRH, NK3R, NKB, sexual dimorphism, reproduction, hypothalamus, sheep

Corresponding author and person to whom reprint requests should be addressed:

Robert Goodman, Ph.D.

PO Box 9229

Department of Physiology and Pharmacology

West Virginia University

Morgantown, WV 26505

Phone: 304-293-1496

Email:rgoodman@hsc.wvu.edu

Disclosure statement: The authors have nothing to disclose 


\section{Abstract:}

Neurokinin B (NKB) is critical for fertility in humans and stimulates GnRH/LH secretion in several species, including sheep. We have proposed that NKB actions in the retrochiasmatic area $(\mathrm{RCh})$ contribute to the induction of the preovulatory LH surge in sheep. In this study, we tested if the response to local administration of senktide, an agonist to the NKB receptor (NK3R), is sexually dimorphic and examined sex differences in NKB and NK3R expression in sheep. To normalize endogenous hormone concentrations, all animals were gonadectomized and given implants to mimic the pattern of ovarian steroids seen in the estrous cycle. In females, senktide microimplants in the $\mathrm{RCh}$ produced a significant increase in LH concentrations that lasted for at least $8 \mathrm{hrs}$ after the start of treatment, while a much shorter increment ( $\sim 2 \mathrm{hrs})$ was seen in males. For neuroanatomical experiments, we collected tissue from gonadectomized lambs $18 \mathrm{hrs}$ after insertion of estradiol implants that produce an LH surge in female, but not male, sheep for immunohistochemical analysis of NKB and NK3R expression. As expected, there were more NKB-containing neurons in the arcuate nucleus of females than males. Interestingly, there was a similar sexual dimorphism in NK3R-containing neurons in the $\mathrm{RCh}$, NKB-containing close contacts onto these RCh NK3R neurons, and overall NKB-positive fibers in this region. These data demonstrate that there are both functional and morphological sex differences in NKB-NK3R signaling in the RCh and raise the possibility that this dimorphism contributes to the sex-dependent ability of estradiol to induce an LH surge in female sheep. 


\section{Introduction:}

The neuroendocrine pathways that control ovulation in females have been the subject of intense investigation over the last fifty years (1-5). High levels of estradiol produced by the maturing follicle(s) act to induce a GnRH surge that in turn elicits a corresponding surge of LH, which then causes ovulation. However, the molecular and neural mechanisms that mediate the interplay between estrogen and $\mathrm{GnRH}$ are still not fully understood. Intermediary neurons must participate in this process since GnRH neurons are devoid of estrogen receptor alpha (ER $\alpha)$ (6), the receptor subtype whereby estrogen exerts its effects.

Kisspeptin signaling was shown to be critical for fertility in humans $(7,8)$ and mice $(8)$ and the role of kisspeptin in controlling GnRH secretion has been extensively examined. Importantly, kisspeptin neurons express ER $\alpha$ in numerous species (9), including sheep (10), supporting the likelihood of a direct effect of estrogen on these neurons. Recently, a population of kisspeptin neurons in the rostral periventricular area of the third ventricle have been demonstrated to mediate the surge-inducing, positive feedback effects of estrogen in female rodents $(2,11)$. In sheep, kisspeptin neurons in both the arcuate (ARC) and preoptic area (POA) appear to participate in the positive feedback effects of estrogen $(12,13)$. A high percentage of kisspeptin neurons located in the ARC, but not in the POA, co-express neurokinin B (NKB) and dynorphin (14) and were thus given the name "KNDy neurons."

Like kisspeptin, mutations in NKB or its cognate receptor, neurokinin receptor 3 (NK3R), preclude pubertal development and lead to hypogonadotropic hypogonadism in humans (15). Subsequent 
work focused on the role of NKB in control of GnRH pulses (16-19), but there has been much less attention paid to the possible role of NKB in regulating the GnRH/LH surge. We have previously demonstrated that senktide, an NK3R agonist, acts in the retrochiasmatic area ( $\mathrm{RCh}$ ) of the ovine hypothalamus to elicit a surge-like increase in LH (20,21). Furthermore, pharmacologic blockade of NK3R signaling within the RCh reduced the amplitude of the LH surge by approximately $50 \%$ (21). This finding demonstrates that NK3R activation in the RCh is essential for full expression of the preovulatory LH surge. Interestingly, administration of microimplants containing senktide into the RCh induced an increase in c-Fos expression in kisspeptin neurons located in the ARC (22). Since neurons in the RCh project directly to KNDy neurons (22), we propose that NK3R neurons in the RCh innervate KNDy neurons in the ARC and provide a circuit by which NKB acts in the RCh to stimulate kisspeptin release, culminating in the GnRH and LH surge in ewes.

While the LH surge is critical for ovulation in females, it typically does not occur in normal males of many species, including rodents (23), sheep (24), and humans (25). Exogenous estrogen treatment, whether alone or preceded by progestin treatment, stimulates surge-like secretion of LH in ovariectomized ewes, but not in castrated rams (26). This lack of responsiveness to high levels of estrogen in rams is likely due to exposure to testosterone during critical developmental periods while in utero, leading to differentiation of neural systems critical for the LH surge $(27,28)$. Adult rams express lower numbers of kisspeptin neurons in the POA and KNDy neurons in the ARC compared to females (29), but these neurons still contain ER $\alpha$ (30) and progesterone receptors (29) in both sexes, which indicates they still have the ability to respond to steroid feedback. These findings raise the possibility that sex differences in components of the NKB-NK3R signaling 
system in the RCh could account, in part, for the inability of estrogen to induce an LH surge in male sheep.

This study was designed to determine if sexual dimorphism exists in the circuitry by which NKB acts in the RCh to stimulate LH secretion. Our objectives were to test this hypothesis by 1) comparing the effect of senktide within the RCh on LH secretion in male and female lambs, 2) comparing NK3R and NKB expression throughout the POA and hypothalamus in male and female lambs, and 3) determining whether sex-specific differences exist in NKB close contacts onto NK3R-immunoreactive (ir) neurons in the RCh. To minimize sex differences in endogenous steroid concentrations, all studies were carried out in gonadectomized lambs that were treated with estradiol and progesterone implants to produce "artificial" luteal and/or follicular phases (31-33).

\section{Material and Methods:}

\section{Animals:}

Blackface ewe-lambs and wethers (rams castrated approximately three weeks after birth) born in February or March were moved from pasture to a quarantine area where they were fed cubed alfalfa hay for 2 weeks. They were then moved indoors to acclimate to housing within the facility for at least one week before surgeries. Once indoors, sheep were allowed free access to water and mineral blocks and were fed cubed alfalfa hay twice daily to maintain body weight. Animals were maintained in a light- and temperature-controlled room with the internal lighting environment 
adjusted to mimic natural changes in day-length. Experiments were performed during the breeding season (December), when animals were 9 to 10 months of age.

\section{General Methods:}

\section{Surgeries}

Ovariectomies (OVX) were performed under aseptic conditions. Animals were first anaesthetized by i.v. injection of ketamine $(7 \mathrm{mg} / \mathrm{kg})$ and midazolam $(0.3 \mathrm{mg} / \mathrm{kg})$ and then maintained on $2 \%$ to $5 \%$ isoflurane in oxygen. Ovarian vasculature was ligated, and the ovaries were removed via a mid-ventral incision. For pharmacological experiments, neurosurgeries were performed in wethers and immediately after OVX of females to implant 18-gauge stainless steel guide tubes into the RCh under general anesthesia as previously described (34). Bilateral (2.5 $\mathrm{mm}$ from midline) guide tubes for the microimplants were lowered to a point just behind the optic chiasm and $1.5 \mathrm{~mm}$ dorsal to the target site, cemented in place, and protected with a plastic cap. Animals were treated preand post-operatively as described previously (35). Briefly, dexamethasone, analgesics (carprofen and gabapentin), and antibiotics (ampicillin and gentamicin) were provided for neurosurgeries and carprofen and ampicillin given to OVX ewes. All pre- and post-operative drugs were acquired

from Patterson Veterinary (Bessemer, AL) except gabapentin, which was compounded locally (McCracken Pharmacy, Waynesburg, PA). Animals were allowed to recover from surgery for at least 1 week before experiments were performed.

\section{Steroid replacement and blood sampling procedures}


We used the following well-described $(32,33,35,36)$ steroid replacement model in both males and females to mimic patterns of ovarian hormones seen during the ovarian cycle: 1) luteal phase levels of estradiol were produced by subcutaneous (sc) insertion a single 1-cm long SILASTIC implant (inner diameter $0.34 \mathrm{~cm}$, outer diameter $0.46 \mathrm{~cm}$; Dow Corning Corp., Midland, MI, USA) containing estradiol; 2) follicular phase levels of estradiol were approximated with four, 3-cm long SILASTIC estradiol implants; and 3) luteal phase progesterone patterns were achieved by inserting 2 Controlled Internal Drug Release (CIDR) devices (Zoetis, Parsippany, NJ) sc and leaving these in place for 10-14 days. Previous studies in ewes demonstrated that sc implantation of CIDRs resulted in levels of plasma progesterone that were similar to vaginally inserted CIDRs (31-33).

Blood samples (3-4 ml) were collected by venipuncture, placed in heparinized tubes and plasma was stored at $-20{ }^{\circ} \mathrm{C}$ until assayed for LH. All procedures were approved by the West Virginia University Animal Care and Use Committee and were performed in accordance with the National Institutes of Health guidelines for the care and use of research animals.

\section{Animal experiments:}

To normalize steroid milieu between sexes, both males and females were treated with estradiol and progesterone (CIDR) implants, as described above, that mimicked luteal phase concentrations of these steroids (36). To determine the effect of estradiol and progesterone treatment on LH secretion in wethers, a preliminary study using cross-bred Suffolk and Hampshire sheep was performed. On day 0, one small estradiol implant and two CIDRs were inserted sc. Eight days 
later, blood samples were collected every 12 minutes for $4 \mathrm{hrs}(\mathrm{E}+\mathrm{P})$, after which CIDRs were removed and frequent blood samples collected the next day (E). Two days after CIDR removal, two new CIDRs were inserted and this process was repeated twice so that males were exposed to a total of three artificial luteal phases. Mean LH levels were similar in the second and third artificial phases (Supplemental Figure 2.1; second phase: E+P, $9.48 \pm 1.99 \mathrm{ng} / \mathrm{mL}$, E, $11.5 \pm 2.0 \mathrm{ng} / \mathrm{mL}$; third phase: $\mathrm{E}+\mathrm{P}, 8.88 \pm 1.20 \mathrm{ng} / \mathrm{mL}, \mathrm{E}, 14.0 \pm 1.22 \mathrm{ng} / \mathrm{mL}$ ), therefore we limited experiments to two or more cycles of artificial luteal phases for subsequent studies using wethers.

\section{Are there sex differences in the effect of senktide microimplants in the $\mathrm{RCh}$ on $\mathrm{LH}$ release in an artificial follicular phase?}

Previous studies have shown that administration of senktide-containing microimplants into the RCh stimulates surge-like LH secretion in ewes $(20,21)$. This experiment compared the effects of senktide administration within the RCh on LH secretion in young wethers $(n=7)$ and ewes $(n=$ 6) using the steroid treatment protocol described above and senktide treatments described in previous work $(20,21)$. After one (ewes) or two (wethers) artificial luteal phases and at least two weeks post-surgery, CIDRs were removed and, the next day, blood samples were collected from 36 minutes before to 8 hours after bilateral insertion of empty- (control) or senktide-containing microimplants into the RCh as previously described (21). Microimplants consisted of sterile 22gauge blunt-ended stainless steel hollow tubes that were cut to extend $1.5 \mathrm{~mm}$ beyond the 18 gauge guide tubes. The ends of the microimplant tubing were tamped at least 60 times in crystalline senktide (Tocris Bioscience; Ellisville, MO) and the exterior wiped clean with sterile gauze immediately before implantation, leaving the lumen tightly packed with senktide crystals. 
Senktide-containing microimplants were inserted after three blood samples (36 minutes), left in place for 4 hours, and then removed and replaced with obturators to occlude guide cannulas. During the first 4 hours and 36 minutes of the sampling period, blood samples were collected at 12-minute intervals. During the subsequent 4 hours, blood samples were collected at 30-minute intervals. At the end of the sampling period, CIDRs were reinserted, and the protocol was repeated using a cross-over design two weeks later so that each animal received both treatments during the

study. At the end of the study, all animals were euthanized and tissue collected for assessment of guide cannula placement.

\section{Tissue collection for comparison of NK3R and NKB expression between males and females}

To determine whether differences exist between males and females in NK3R-containing cell populations and/or NKB-containing neurons, young male $(n=6)$ and female $(n=5)$ sheep at 9 to 10 months of age received two sequential artificial luteal phases as described above. Females were OVX two weeks before the start of steroid treatment to allow time for mean LH levels to rise to that of wethers. On the eighth day of the second artificial luteal phase, CIDRs were removed and the following day, four 3-cm long implants containing estradiol were inserted. Eighteen hours later, animals were euthanized and tissue blocks were obtained as described below. Blood samples were collected every 12 min for 2 hours just before tissue collection.

\section{Tissue collection:}


Hypothalamic tissue blocks were collected for immunohistochemical analysis and for histological examination of guide cannula placements as previously described (35). Briefly, animals were treated with heparin $(20,000 \mathrm{U}) 10$ minutes before and at the time of euthanasia, which was accomplished by an intravenous overdose of sodium pentobarbital ( 8 to $12 \mathrm{~mL}$, Euthasol; Patterson Veterinary, Bessemer, AL). Once respiration stopped and there was no eye-blink reflex, the animal was exsanguinated by cutting the carotids, and the head rapidly removed and perfused via the carotid arteries with $4 \mathrm{~L}$ of a solution containing $4 \%$ paraformaldehyde in $0.1 \mathrm{M}$ phosphate buffer (PB) with $0.1 \%$ sodium nitrite. Tissue blocks containing the POA and hypothalamus were removed and stored overnight in the paraformaldehyde solution at $4^{\circ} \mathrm{C}$. The following day, blocks were transferred to a solution containing $20 \%$ sucrose in $0.1 \mathrm{M} \mathrm{PB}$ and stored at $4^{\circ} \mathrm{C}$. A microtome with a freezing stage was used to section blocks in $45-\mu \mathrm{m}$ increments. For the pharmacological experiment, every fifth section through the RCh was stained with cresyl violet and examined for guide cannula placement. For neuroanatomical experiments, 10 parallel series of sections $(450 \mu \mathrm{m}$ apart) were stored in cryoprotectant (37) at $-20^{\circ} \mathrm{C}$.

\section{Immunohistochemistry:}

For detection of NK3R and NKB, dual-label immunohistochemistry was performed on a complete series of free-floating hemi-sections throughout the hypothalamus from each animal. All washes were performed at room temperature under gentle agitation with phosphate buffered saline (PBS). Sections were rinsed 4 times for 5 minutes between incubations unless noted otherwise. On the first day, tissue sections were rinsed thoroughly 12 times for 15 minutes each time. After PBS washes, tissue sections were incubated for 1 hour in $1 \% \mathrm{H}_{2} \mathrm{O}_{2}$ for 10 minutes, rinsed, and incubated 
in 20\% normal goat serum (Jackson Immunoresearch, West Groove, PA) in PBS containing 0.4\% triton X-100 (NGS) before overnight incubation with rabbit anti-NKB (dilution 1:5,000 in 4\% NGS; Phoenix, Catalog \#H-026-06, Lot 01297-2). On the second day, sections were rinsed and then incubated in biotinylated goat anti-rabbit immunoglobin (1:500 in 4\% NGS; Vector BA-1000, Lot ZA0520) for 1 hour, followed by ABC-elite (1:500 in PBS; Vector Laboratory Burlingame, CA) for 1 hour. Sections were rinsed again and incubated for 10 minutes in biotinylated tyramine (TSA) (dilution 1:250; Perkin Elmer, Waltham, MA, USA) in PBS containing 3\% $\mathrm{H}_{2} \mathrm{O}_{2}$ per $1 \mathrm{~mL}$ of solution. After rinsing, sections were incubated in DyLight green 488-conjugated to streptavidin (1:100 in PBS; Fisher Scientific) for 30 minutes, followed by rinses and incubation for 1 hour in 4\% NGS. Sections were incubated overnight with rabbit anti-NK3R (dilution 1:1,000 in 4\% NGS; Novus, Catalog \#NB300-102, Lot F1). On the third day, sections were rinsed and then incubated in Alexa555 goat anti-rabbit (dilution 1:100 in 4\% NGS; Life Technologies, Carlsbad, CA, USA) for 30 minutes. Sections were rinsed again before being incubated with Neurotrace 640/600 Deep Red Fluorescent Nissl Stain (1:100 in PBS; Life Technologies; Lot N21483) for 20 minutes. Sections were then rinsed in phosphate buffer (PB), mounted on charged Superfrost slides (Fisher Scientific), cover-slipped using Gelvatol and stored in the dark at $4{ }^{\circ} \mathrm{C}$ until analyzed.

\section{Analysis of NK3R-ir cells in the POA and RCh, and NKB-ir cells in ARC:}

The total number of NK3R-ir cells in the POA and RCh, and the average number of NKB-ir cells/section in the ARC were assessed using an upright fluorescent microscope (VS120; Olympus, Tokyo, Japan) with a 20x objective. The total number of NK3R-ir cells represents the sum of cell numbers in three representative POA hemi-sections that included, or were just posterior to, the 
organum vasculosum of lamina terminalis $(33,38)$. The area analyzed in the RCh extended in the lateral direction from the fornix to the medial edge of the optic tract, dorsally from the fornix to the base of the brain and approximately $1.4 \mathrm{~mm}$ (three hemi-sections) posterior to the optic chiasm $(33,38)$. NKB cell numbers were averaged across $3-4$ hemi-sections containing the middle to caudal ARC per animal (14). All cell counts were made by an observer blinded to treatment groups.

\section{Analysis of NK3R-ir fibers in the ARC and NKB-ir fibers and close contacts on NK3r-ir neurons in the RCh:}

In order to assess NK3R fiber intensity in the ARC and NKB fiber intensity in the RCh, 4 images were captured across at least two hemi-sections per animal using a Hamamatsu Orca Flash 4.0 monochrome cMOS camera on a Nikon A1R confocal microscope (Nikon Instruments Inc., Melville, NY) with a Plan Apochromat VC 20X DIC N2/ 0.8 WD (1 mm) objective. Confocal Zstacks of optical sections were taken at $1 \mu \mathrm{m}$ intervals throughout each section and the settings for each laser $(488,561,640)$ were identical across all images to allow for comparisons. NIS-Elements software was used for image processing by the ROI statistical tools to measure mean pixel intensity across a Z-stack; each image area measured 512 x 512 pixels. A threshold signal was established and applied to all images before the number of objects was determined by the ROI standard. To examine the number of NKB close-contacts onto NK3R-containing neurons in the RCh, images of 10 neurons were captured across at least 2 sections in the RCh for each animal using the confocal microscope with a 60X Oil/1.4 WD $(130 \mu \mathrm{m})$ objective. Confocal Z-stacks of optical sections were taken at $1 \mu \mathrm{m}$ intervals through each neuron. The number of close-contacts onto cell bodies was 
analyzed using the Nikon software, NIS Elements, and orthogonal views were used to confirm that contacts were touching the cell in all planes.

\section{Radioimmunoassay:}

Radioimmunoassays for LH were performed as previously described for ovine samples (39). Briefly, LH concentrations were measured in duplicate using $100-200 \mu \mathrm{L}$ of plasma per sample via a double-antibody radioimmunoassay with reagents supplied by the National Hormone and Peptide Program (Torrance, CA, USA). The sensitivity of the assay averaged $0.06 \mathrm{ng} / \mathrm{tube}$, and the intra- and interassay variability were $13.4 \%$ and $14.1 \%$, respectively.

\section{Statistical analysis:}

In Experiment 1, 4 of 6 females and 4 of 7 males were considered to have correct RCh placements of guide cannulas. Animals with misplaced cannulas were omitted from statistical analysis. Comparison of the effect of senktide-containing microimplants to blank microimplants for the total sampling period or hourly time blocks was done using two-way ANOVA with repeated measures (influence of time and treatment within sex) with Holm-Sidak post-hoc analysis used for pairwise multiple comparison. The total number of NK3R cells in the POA and RCh, NK3R fiber intensity in the ARC, average number of $\mathrm{NKB}$ cells in the ARC, average number of NKB contacts onto NK3R-positive cells in the RCh, and NKB fiber intensity in the RCh were compared between sexes with independent t-tests. Data are reported as mean \pm SEM. Differences were considered significant when $\mathrm{P}<0.05$. 


\section{Results}

\section{Are there sex differences in the effect of senktide microimplants in the RCh on $\mathrm{LH}$ release in an artificial follicular phase?}

Placement of guide cannulas is shown in Fig. 2.1A; incorrect placements were either rostral or caudal to the RCh. In ewes with correct placements $(n=4 / s e x)$, senktide administration into the $\mathrm{RCh}$ resulted in sustained increases in LH secretion (Fig. 2.1B). LH concentrations in response to senktide were significantly higher than control treatments at approximately 1 hour after drug administration (Fig. 2.1C) and remained significantly elevated for at least 7 hours. Mean LH concentrations in females for the entire sampling period after administration of senktide-containing microimplants was significantly higher compared to those with empty microimplants (Fig. 2.2A). From 0 to 1 hour, there was no significant effect of senktide on $\mathrm{LH}$ secretion $(\mathrm{P}=0.20)$. However, for the remainder of the sampling period, mean LH concentration was significantly increased by senktide treatment in females $(\mathrm{P} \leq 0.03)$ (Fig. 2.2B). In males, $\mathrm{LH}$ concentrations were transiently elevated for a total of 2 hours, starting approximately 1.5 hours after senktide administration (Fig. 2.1C). There was no significant effect of senktide on $\mathrm{LH}$ secretion for the entire sampling period (Fig 2.2A) or from 0 to 2 hours $(\mathrm{P} \geq 0.10)$ and 5 to 8 hours $(\mathrm{P} \geq 0.20)$ post-implantation (Fig. 2.2C). However, from 2 to 5 hours post-implantation of senktide-containing microimplants, LH concentrations were higher than those following insertion of empty implants $(\mathrm{P} \leq 0.05)$ (Fig. 2.2C). 


\section{Are NK3R-containing cell populations throughout the POA and hypothalamus sexually dimorphic?}

As expected, mean LH concentrations were much higher in females compared to males at the time of tissue collection, when an LH surge was occurring in many females, but no males (97.9 \pm 38.6 $\mathrm{ng} / \mathrm{mL}$ vs $3.82 \pm 0.61 \mathrm{ng} / \mathrm{mL}$ ). In agreement with previous work (38), NK3R-cell populations throughout the POA and hypothalamus appeared morphologically distinct depending on region. In our observations, regardless of sex, NK3R-ir neurons in the POA (Fig. 2.3A - D) were bipolar, parvicellular neurons that were approximately $12 \mu \mathrm{m}$ in somal diameter, while those in the $\mathrm{RCh}$ (Fig. 2.4A - E) were larger, multipolar neurons that were greater than $20 \mu \mathrm{m}$ in somal diameter. Regardless of sex or neuroanatomical area, NK3R-positive neuronal projections were long, fibrous, and readily visualized. The number of NK3R-ir cells in the POA (Fig. 2.3E) and RCh (Fig. 2.4F) was greater in females than in males (POA, female $216 \pm 30.7$ vs male $109.5 \pm 14.2$ cells; RCh, female $133.8 \pm 9.7$ vs male $88.3 \pm 11.4$ cells).

In the ARC, NKB neurons were readily visualized for both sexes in the middle to caudal ARC and presented with parvicellular morphology typical of KNDy neurons (Fig. 2.5A and B). NK3Rexpressing cells were highly dense in the middle to caudal ARC irrespective of sex. The majority of NK3R staining was punctate, in contrast to NK3R-ir in the POA and RCh, where staining was largely cytoplasmic and cell bodies were more readily visible. Additionally, nearly all NKB cells had close contacts with NK3R-positive fibers and a high number of NK3R varicosities were visible in the ARC. There was no difference between sexes in NK3R-positive mean fiber intensity in the ARC (females, 24,888 $\pm 8,468$ intensity units; males, 31,799 $\pm 8,855$ intensity units). The average 
number of NKB neurons in the ARC was greater in females than in males (Fig. 2.5C; female 60.9 \pm 4.2 vs male $24.3 \pm 3.6$ cells) which is in agreement with what is previously described in adults $(29,30,40)$ and prenatal testosterone-treated females $(30,33)$.

\section{Are NKB projections to the RCh sexually dimorphic?}

As illustrated by representative photomicrographs in Figure 2.6, there was a greater number of NKB-ir inputs to NK3R-containing neurons in the RCh in females than in males $(4.59 \pm 1.16$ contacts/cell vs. $0.41 \pm 0.32$ contacts/cell) and this was reflected in less overall NKB-ir in this region: mean pixel intensity for NKB staining was greater in females compared to males $(5,831 \pm$ 1,476 vs. $1,480 \pm 413$ intensity units).

\section{Discussion}

These data provide evidence for differences within the RCh that may contribute to the sexual dimorphism of the estrogen-induced LH surge in sheep. Several studies have demonstrated the importance of NKB-NK3R signaling in the RCh and the potential for this system to play a role in surge-like LH release by acting via KNDy neurons in the ARC in females $(13,20-22)$, but this system has not been examined in males. In the current study, we showed that senktide administration in the RCh resulted in continuous, surge-like LH release in female, but not male, sheep. Moreover, we demonstrated that the number of NK3R-containing neurons in the RCh and the number of NKB inputs per NK3R cell in the RCh was greater for females than males when both were exposed to levels of estradiol sufficient for surge generation in females. These results 
point to the $\mathrm{RCh}$ as a site of functional and morphological sex differences in NKB-NK3R signaling.

We observed obvious differences in the patterns of $\mathrm{LH}$ release in response to $\mathrm{RCh}$ senktide administration between males and females. In agreement with previous findings $(21,22)$, LH release following administration of senktide in the RCh was elevated and prolonged in females. This pattern of LH secretion is more typical of an LH surge, which lasts approximately 12 hours in sheep (41), than episodic LH secretion, and supports the hypothesis that NKB activity within the RCh is important for the LH surge in females. In contrast, while increased LH release was evident in males, this elevation was transient, lasting only about 2 hours. In addition to prolonged LH release, the onset of the $\mathrm{LH}$ response to senktide occurred sooner in females compared to males. While the percent increase in mean LH concentrations after senktide administration was higher in females than in males $(\sim 160 \%$ vs $47 \%)$, the absolute change in LH concentrations was similar (both $\sim 9 \mathrm{ng} / \mathrm{mL}$ ). Comparison of these changes is complicated by the fact that baseline $\mathrm{LH}$ concentrations in wethers were much higher than in OVX females. This is surprising because such differences were not seen in the preliminary study or in the wethers from which tissue was collected for analysis of NK3R and NKB expression. Nonetheless, while the immediate response to senktide may have been quantitatively similar between males and females, the long-term response was clearly not. The simplest explanation for this sexual dimorphism is that NK3R-ir neurons residing within the $\mathrm{RCh}$ are more numerous in females than in males. Thus, this population would be expected to be more readily activated and able to produce a quicker response. The more prolonged response in females may also be due to more numerous NK3R-ir neurons in the RCh or the greater number of KNDy neurons in the ARC of females because activation of the former acts 
through ARC kisspeptin release to influence LH secretion (22). Regardless, the temporal differences between the sexes in response to senktide provide functional evidence for sexual dimorphism in NKB-NK3R signaling in the RCh of sheep.

This is the first evidence in sheep that activation of NK3R can stimulate LH secretion in males. However, there is evidence in monkeys that NK3R signaling can increase LH release in males. Specifically, NKB or senktide injected as an intravenous bolus elicited a robust discharge of LH from GnRH-primed pituitary juvenile male monkeys (42). Furthermore, this LH release was abolished by pre-treatment with a GnRH-R antagonist, establishing the GnRH dependency of the induced LH release, and indicating that the site of action of the NK3R agonists. Repetitive activation of NK3R in these monkeys failed to sustain robust pulsatile GnRH release, unlike the effect of repetitive activation of KISS1R (42). In contrast, recent studies of male mice demonstrated that intraperitoneal and intracerebroventricular administration of NKB was not associated with LH release (43). It should also be pointed out that the effects of NKB and/or senktide in male sheep and monkeys indicate that NK3R signaling can increase LH, but the physiological importance of this await studies with NK3R antagonists.

In this study, we observed that the total number of NK3R-containing cells in the POA and RCh was lower in males than females when tissue was collected in the presence of surge-inducing levels of estradiol. This is in contrast to what is found in prenatal testosterone-treated females (33), in which no effect of testosterone treatment on the number of NK3R-containing cells was found for either the POA or RCh. These apparently contradictory results are likely not due to differences in hormonal milieu because tissue was collected during an "artificial follicular phase" in both studies. 
Instead they are most likely explained by differences in animal models because females born to testosterone-treated mothers still exhibit some aspects of female reproductive function, including a blunted LH surge, for at least two years after birth $(27,44)$. Thus, lambs born to prenatally testosterone-treated females may represent an intermediate neuroanatomical state between normal males and females. This possibility is consistent with the report of Cheng et al., (29) that prenatal testosterone treatment failed to reduce the number of kisspeptin-ir cells in the ARC to levels comparable to that seen in normal male brains (29).

In contrast to NK3R expression in the RCh and POA, the observation that the number of $\mathrm{NKB}$ cells in the ARC is higher in young females compared to young males is in agreement with previous results in young and adult intact rams $(30,40)$ and prenatally testosterone-treated females (33). In the ARC, mean NK3R fiber intensity did not differ between males and females. This is in contrast with an earlier report of a small decrease in NK3R-ir cells in prenatally testosteronetreated females (31), and may reflect the likelihood that many of these fibers arise from neurons outside the ARC. We did not assess NK3R-ir in ARC NKB cells because it was difficult to accurately distinguish between NK3R-ir bound to the cell membrane from NK3R-ir close contacts due to the punctate nature of this staining.

We observed dramatic sex differences in the extent of NKB-ir fibers and NKB-containing inputs onto NK3R-ir cells in the RCh, both of which were approximately four times greater in females than in males. The presence of NKB-containing fibers in the RCh is in agreement with previous findings in female sheep (38). However, the origin of these fibers is unknown. In sheep, nearly all NKB-ir neurons are located in the $\operatorname{ARC}(30,45)$, and the vast majority of these neurons also contain 
kisspeptin (14). However, these KNDy neurons do not project to the RCh because few, if any, kisspeptin-ir fibers are seen in this region (9). There is evidence that some cells in the ARC project to the RCh, but these cells did not colocalize with kisspeptin (22). Thus, the source of the NKB inputs seen in the RCh could be the small population of NKB neurons in the ARC that do not coexpress kisspeptin (14) or other NKB-producing cells that cannot be detected by immunohistochemistry because the peptide is rapidly transported to terminals. Further studies using other approaches such as in situ hybridization are needed to distinguish between these two possibilities.

The decreased NKB/NK3R signaling found in males may underlie the sexual dimorphism in both the response to senktide and the failure of males to produce GnRH/LH surges. The decreased number of NK3R-containing neurons in the RCh of males provides a simple explanation for the attenuated LH response to local administration of senktide in this area. However, the ability of senktide to increase LH secretion in males indicates that differences in NK3R expression cannot account, by itself, for the lack of an estrogen-induced LH surge. Thus, one can infer that the decrease in NKB input to this region in males likely contributes to the sexual dimorphism in estrogen positive feedback in sheep. These findings also support the hypothesis that the population of NK3R-containing cells in the RCh is necessary for full expression of the LH surge in females (21). These cells are thought to increase $\mathrm{GnRH} / \mathrm{LH}$ secretion during a surge by activating release of kisspeptin from KNDy cells in the ARC (22). Thus, the lower number of KNDy cells in the ARC of males could also contribute to the sexual dimorphism seen in the inability of males to generate an LH surge. 
In summary, we report morphological and functional evidence of sexual dimorphism in NKBNK3R signaling in the ovine RCh. Senktide administration in the RCh resulted in prolonged, surge-like LH release in female, but not male, sheep. This finding is associated with fewer NK3Rpositive cells and NKB contacts onto NK3R-containing cells in the RCh, and fewer NKB cells in the ARC of males. Therefore, we propose that deficiencies in NKB inputs to the RCh, the response to NKB in the RCh, and in the ability of KNDy neurons to respond to a stimulus from the RCh all contribute to the sex-dependent expression of the GnRH/LH surge in sheep.

\section{Acknowledgements}

We thank Miroslav Valent, Gail Sager, and John Connors for technical assistance with radioimmunoassay and animal surgeries. We also thank Drs. Margaret Minch and Jennifer Fridley for veterinary care, Heather Bungard for care of the sheep, and Dr. Al Parlow and the National Hormone and Peptide program for reagents used to measure LH.

Image capture and image analysis were performed in the West Virginia University (WVU) Microscope Imaging Facility, which has been supported by the WVU Cancer Institute and NIH Grants P20 RR016440, U54 GM104942, and P20 GM103434. We thank Dr. Amanda Ammer for assistance in image analysis and processing.

This work was supported by National Institutes of Health (NIH) Grants R01-HD039916, R01HD082135, and P20GM103434 to the West Virginia IDeA Network for Biomedical Research Excellence. 
Disclosure Summary: The authors have nothing to disclose. 


\section{References:}

1. Levine JE. New concepts of the neuroendocrine regulation of gonadotropin surges in rats. Biol. Reprod. 1997;56(2):293-302.

2. Khan AR, Kauffman AS. The role of kisspeptin and RFamide-related peptide-3 neurones in the circadian-timed preovulatory luteinising hormone surge. J. Neuroendocrinol. 2012;24(1):131-143.

3. Plant TM. A comparison of the neuroendocrine mechanisms underlying the initiation of the preovulatory LH surge in the human, Old World monkey and rodent. Front. Neuroendocrinol. 2012;33(2):160-168.

4. Clarke IJ. The preovulatory LH surge. A case of a neuroendocrine switch. Trends Endocrinol. Metab. 1995;6(7):241-247.

5. Goodman RL. Neuroendocrine Control of Gonadotropin Secretion: Comparative Aspects. In: Knobil and Neill's Physiology of Reproduction.; 2015:1537-1574.

6. Lehman MN, Karsch FJ. Do gonadotropin-releasing hormone, tyrosine hydroxylase-, and $\beta$-endorphin-immunoreactive neurons contain estrogen receptors? A double-label immunocytochemical study in the suffolk ewe. Endocrinology 1993;133(2):887-895.

7. de Roux N, Genin E, Carel J-C, Matsuda F, Chaussain J-L, Milgrom E. Hypogonadotropic hypogonadism due to loss of function of the KiSS1-derived peptide receptor GPR54. Proc. Natl. Acad. Sci. 2003. doi:10.1073/pnas.1834399100.

8. Seminara SB, Messager S, Chatzidaki EE, Thresher RR, Acierno JS, Shagoury JK, Bo-Abbas Y, Kuohung W, Schwinof KM, Hendrick AG, Zahn D, Dixon J, Kaiser UB, Slaugenhaupt SA, Gusella JF, O'Rahilly S, Carlton MBL, Crowley WF, Aparicio SAJR, Colledge WH. The GPR54 Gene as a Regulator of Puberty. Obstet. Gynecol. Surv. 2004. doi:10.1097/00006254-200405000-00020.

9. Lehman MN, Hileman SM, Goodman RL. Neuroanatomy of the kisspeptin signaling system in mammals: Comparative and developmental aspects. Adv. Exp. Med. Biol. 2013;784:27-62.

10. Franceschini I, Lomet D, Cateau M, Delsol G, Tillet Y, Caraty A. Kisspeptin immunoreactive cells of the ovine preoptic area and arcuate nucleus co-express estrogen receptor alpha. Neurosci. Lett. 2006;401(3):225-230.

11. Herbison AE. Estrogen positive feedback to gonadotropin-releasing hormone (GnRH) neurons in the rodent: The case for the rostral periventricular area of the third ventricle (RP3V). Brain Res. Rev. 2008;57(2):277-287.

12. Smith JT, Li Q, Pereira a., Clarke IJ. Kisspeptin neurons in the ovine arcuate nucleus and preoptic area are involved in the preovulatory luteinizing hormone surge. Endocrinology 2009;150(12):5530-5538.

13. Merkley CM, Porter KL, Coolen LM, Hileman SM, Billings HJ, Drews S, Goodman RL, Lehman MN. KNDy (kisspeptin/neurokinin B/dynorphin) neurons are activated during both pulsatile and surge secretion of LH in the ewe. Endocrinology 2012;153(11):5406-5414.

14. Goodman RL, Lehman MN, Smith JT, Coolen LM, De Oliveira CVR, Jafarzadehshirazi MR, Pereira A, Iqbal J, Caraty A, Ciofi P, Clarke IJ. Kisspeptin neurons in the arcuate nucleus of the ewe express both dynorphin A and neurokinin B. Endocrinology 2007. doi:10.1210/en.2007-0961.

15. Topaloglu a K, Reimann F, Guclu M, Yalin AS, Kotan LD, Porter KM, Serin A, 
Mungan NO, Cook JR, Ozbek MN, Imamoglu S, Akalin NS, Yuksel B, O'Rahilly S, Semple RK. TAC3 and TACR3 mutations in familial hypogonadotropic hypogonadism reveal a key role for Neurokinin B in the central control of reproduction. Nat. Genet. 2009;41(3):354-358.

16. Nestor CC, Briscoe AMS, Davis SM, Valent M, Goodman RL, Hileman SM. Evidence of a role for kisspeptin and neurokinin B in puberty of female sheep. Endocrinology 2012;153(6):2756-2765.

17. Goodman RL, Hileman SM, Nestor CC, Porter KL, Connors JM, Hardy SL, Millar RP, Cernea M, Coolen LM, Lehman MN. Kisspeptin, neurokinin B, and dynorphin act in the arcuate nucleus to control activity of the GnRH pulse generator in ewes. Endocrinology 2013;154(11):4259-4269.

18. Wakabayashi Y, Nakada T, Murata K, Ohkura S, Mogi K, Navarro VM, Clifton DK, Mori Y, Tsukamura H, Maeda K-I, Steiner R a, Okamura H. Neurokinin B and dynorphin A in kisspeptin neurons of the arcuate nucleus participate in generation of periodic oscillation of neural activity driving pulsatile gonadotropin-releasing hormone secretion in the goat. J. Neurosci. 2010;30(8):3124-3132.

19. Navarro VM; Gottsch ML; Chavkin C; Okamura H; Clifton DK; Steiner RA. Regulation of Gonadotropin-Releasing Hormone Secretion by Kisspeptin / Dynorphin / Neurokinin B Neurons in the Arcuate Nucleus of the Mouse. J. Neurosci. 2009;29(38):11859-11866.

20. Billings HJ, Connors JM, Altman SN, Hileman SM, Holaskova I, Lehman MN, McManus CJ, Nestor CC, Jacobs BH, Goodman RL. Neurokinin B acts via the neurokinin-3 receptor in the retrochiasmatic area to stimulate luteinizing hormone secretion in sheep. Endocrinology 2010;151(8):3836-3846.

21. Porter KL, Hileman SM, Hardy SL, Nestor CC, Lehman MN, Goodman RL. Neurokinin-3 Receptor Activation in the Retrochiasmatic Area is Essential for the Full Preovulatory LH Surge in Ewes. J. Neuroendocrinol. 2014. doi:10.1111/jne.12180.

22. Grachev P, Porter KL, Coolen LM, McCosh RB, Connors JM, Hileman SM, Lehman MN, Goodman RL. Surge-Like Luteinising Hormone Secretion Induced by Retrochiasmatic Area NK3R Activation is Mediated Primarily by Arcuate Kisspeptin Neurones in the Ewe. J. Neuroendocrinol. 2016;28(6). doi:10.1111/jne.12393.

23. Corbier P. Sexual differentiation of positive feedback: Effect of hour of castration at birth on estradiol-induced luteinizing hormone secretion in immature male rats. Endocrinology 1985;116(1):142-147.

24. Herbosa CG, Dahl GE, Evans NP, Pelt J, Wood RI, Foster DL. Sexual differentiation of the surge mode of gonadotropin secretion: Prenatal androgens abolish the gonadotropin-releasing hormone surge in the sheep. J. Neuroendocrinol. 1996;8(8):627633.

25. VAN LOOK PFA, HUNTER WM, CORKER CS, BAIRD DT. FAILURE OF POSITIVE FEEDBACK IN NORMAL MEN AND SUBJECTS WITH TESTICULAR FEMINIZATION. Clin. Endocrinol. (Oxf). 1977;7(5):353-366.

26. Stormshak F, Estill CT, Resko JA, Roselli CE. Changes in LH secretion in response to an estradiol challenge in male- and female-oriented rams and in ewes. Reproduction 2008;135(5):733-738.

27. Wood RI, Foster DL. Sexual differentiation of reproductive neuroendocrine function in sheep. Rev. Reprod. 1998;3(2):130-140. 
28. Foster DL, Padmanabhan V, Wood RI, Robinson JE. Sexual differentiation of the neuroendocrine control of gonadotrophin secretion: concepts derived from sheep models. Reprod. Suppl. 2002;59:83-99.

29. Cheng G. Coolen LM. Padmanabhan V. Goodman RL. Lehman M. The kisspeptin/neurokinin B/dynorphin (KNDy) cell population of the arcuate nucleus: sex differences and effects of prenatal. Endocrinology 2010;151(1):301-311.

30. Goubillon ML, Forsdike RA, Robinson JE, Ciofi P, Caraty A, Herbison AE. Identification of neurokinin B-expressing neurons as an highly estrogen-receptive, sexually dimorphic cell group in the ovine arcuate nucleus. Endocrinology 2000;141(11):4218-4225.

31. Robinson JE, Forsdike RA, Taylor JA. In utero exposure of female lambs to testosterone reduces the sensitivity of the gonadotropin-releasing hormone neuronal network to inhibition by progesterone. Endocrinology 1999;140(12):5797-5805.

32. Jackson LM, Mytinger A, Roberts EK, Lee TM, Foster DL, Padmanabhan V, Jansen HT. Developmental programming: Postnatal steroids complete prenatal steroid actions to differentially organize the GnRH surge mechanism and reproductive behavior in female sheep. Endocrinology 2013;154(4):1612-1623.

33. Ahn T, Fergani C, Coolen LM, Padmanabhan V, Lehman MN. Prenatal Testosterone Excess Decreases Neurokinin 3 Receptor Immunoreactivity within the Arcuate Nucleus KNDy Cell Population. J. Neuroendocrinol. 2015;27(2):100-110.

34. Anderson GM, Connors JM, Hardy SL, Valent M, Goodman RL. Oestradiol microimplants in the ventromedial preoptic area inhibit secretion of luteinizing hormone via dopamine neurones in anoestrous ewes. J. Neuroendocrinol. 2001;13(12):1051-1058.

35. McCosh RB, Szeligo BM, Bedenbaugh MN, Lopez JA, Hardy SL, Hileman SM, Lehman MN, Goodman RL. Evidence that endogenous somatostatin inhibits episodic, but not surge, secretion of LH in female sheep. Endocrinology 2017;158(6):1827-1837.

36. Skinner DC, Harris TG, Evans NP. Duration and amplitude of the luteal phase progesterone increment times the estradiol-induced luteinizing hormone surge in ewes. Biol. Reprod. 2000;63(4):1135-42.

37. Watson RE, Wiegand SJ, Clough RW, Hoffman GE. Use of cryoprotectant to maintain long-term peptide immunoreactivity and tissue morphology. Peptides 1986;7(1):155-159.

38. Amstalden M, Coolen LM, Hemmerle AM, Billings HJ, Connors JM, Goodman RL, Lehman MN. Neurokinin 3 receptor immunoreactivity in the septal region, preoptic area and hypothalamus of the female sheep: Colocalisation in neurokinin B cells of the arcuate nucleus but not in gonadotrophin-releasing hormone neurones. J. Neuroendocrinol. 2010;22(1):1-12.

39. Goodman RL, Coolen LM, Anderson GM, Hardy SL, Valent M, Connors JM, Fitzgerald ME, Lehman MN. Evidence that dynorphin plays a major role in mediating progesterone negative feedback on gonadotropin-releasing hormone neurons in sheep. Endocrinology 2004;145(6):2959-2967.

40. Nestor CC, Briscoe AMS, Davis SM, Valent M, Goodman RL, Hileman SM. Evidence of a role for kisspeptin and neurokinin B in puberty of female sheep. Endocrinology 2012;153(6):2756-2765.

41. Moenter SM, Caraty A, Karsch FJ. The estradiol-induced surge of gonadotropinreleasing hormone in the Ewe. Endocrinology 1990;127(3):1375-1384.

42. Ramaswamy S, Seminara SB, Ali B, Ciofi P, Amin NA, Plant TM. Neurokinin B 
stimulates GnRH release in the male monkey (Macaca mulatta) and is colocalized with kisspeptin in the arcuate nucleus. Endocrinology 2010. doi:10.1210/en.2010-0223.

43. Corander MP, Challis BG, Thompson EL, Jovanovic Z, Loraine Tung YC, Rimmington D, Huhtaniemi IT, Murphy KG, Topaloglu AK, Yeo GSH, O'Rahilly S, Dhillo WS, Semple RK, Coll AP. The effects of neurokinin B upon gonadotrophin release in male rodents. J. Neuroendocrinol. 2010. doi:10.1111/j.13652826.2009.01951.x.

44. Birch RA, Padmanabhan V, Foster DL, Unsworth WP, Robinson JE. Prenatal programming of reproductive neuroendocrine function: Fetal androgen exposure produces progressive disruption of reproductive cycles in sheep. Endocrinology 2003;144(4):14261434.

45. Foradori CD, Amstalden M, Goodman RL, Lehman MN. Colocalisation of dynorphin A and neurokinin B immunoreactivity in the arcuate nucleus and median eminence of the sheep. J. Neuroendocrinol. 2006;18(7):534-541. 


\section{Figure Legends}

Figure 2.1. Effect of microimplants containing senktide or blank (control) implants in the RCh on LH secretion during an artificial follicular phase in female and male sheep ( $n=4$ /group). (A) Guide cannula placement in the RCh. Grey circles represent guide cannula placements in males while white circles represent guide cannula placements in females. (B) Individual LH profiles in a female and male sheep with either blank (closed circle) or senktide-containing (open circle) microimplants in the RCh. Microimplants were inserted at time 0. (C) Mean LH concentrations for each group. *First sample that was significantly greater than controls following senktide treatment.

Figure 2.2. Effect of blank (control) microimplants or microimplants containing senktide in the RCh on LH secretion during an artificial follicular phase in female and male sheep. (A) Mean LH levels for the $8 \mathrm{hrs}$ after insertion of microimplants into the RCh in males and females. Mean LH response in females (B) and males (C) during hourly time intervals after administration of blank or senktide-containing microimplants into the RCh (two-way ANOVA with repeated measures, $\mathrm{n}=4$ /group; $\mathrm{p}<0.05^{*}$ vs control treatment).

Figure 2.3. NK3R immunoreactivity in the POA of female and male sheep. Panels A and B present low magnification images illustrating NK3R (red) immunoreactivity and NeuroTrace 640/660 fluorescent Nissl staining (blue) in the POA of a female and male sheep, respectively. Higher magnification images of areas identified by the dashed, white boxes are presented in Panels $\mathrm{C}$ (female sheep) and D (male sheep). Scale bar in A, B = 200 $\mu \mathrm{m}$. Scale bar in C, D = $100 \mu \mathrm{m}$. 
Arrows indicate some NK3R-containing cells. (E) Bar graphs compare the total number of NK3Rir neurons in the POA of female and male sheep ( $\mathrm{p}<0.05^{*}$ vs male).

Figure 2.4. NK3R immunoreactivity in the RCh of female and male sheep. Panels A and B present low magnification images illustrating NK3R (red) immunoreactivity and Nissl staining (blue) in the RCh of a female and male sheep, respectively. Higher magnification images of areas identified by the dashed, white boxes are presented in Panels C (female sheep) and D (male sheep). (E) Confocal image (1 $\mu \mathrm{m}$ optical section) of a NK3R-containing cell in the RCh of a female sheep. Scale bars: A, B $=500 \mu \mathrm{m} ; \mathrm{C}, \mathrm{D}=100 \mu \mathrm{m} ; \mathrm{E}=50 \mu \mathrm{m}$. Arrows indicate some NK3R containing cells. (F) Bar graphs compare the total number of NK3R-ir neurons in the RCh of female and male sheep ( $<<0.05^{*}$ vs male).

Figure 2.5. NKB immunoreactivity in the ARC of female and male sheep. (A) Left: Photomicrograph illustrating NKB (green) immunoreactivity and Nissl staining (blue) in the ARC of a female (A) and male (B) sheep. Scale bar $=100 \mu \mathrm{m}$. Arrows indicate some NKB cells. (C) Right: The average number of NKB neurons in the ARC of female and male sheep $\left(\mathrm{p}<0.05^{*}\right.$ vs male).

Figure 2.6. NKB and NK3R immunoreactivity in the RCh of female and male sheep. Photomicrographs of confocal images ( $1 \mu \mathrm{m}$ thick optical section) illustrating NKB (green), Nissl staining (blue), and NK3R (red) in the RCh of female (A) or male (B) sheep. Thin yellow line in merged images (bottom left panel) represents cursor tool used to examine cell contacts by orthogonal projections. White arrowheads represent contacts. Scale bar $=50 \mu \mathrm{m}$. 
Supplemental Figure 2.1. Steroid-induced suppression of LH secretion in wethers. Phase 0 represents pre-treatment mean LH levels in the absence of steroids. At day 0 , one small $(1 \mathrm{~cm})$ Silastic-brand implant containing estradiol was inserted sc and remained in place for the entire experiment period. Two progesterone-containing CIDRs were also inserted sc at this time (E+P; Phase I). Eight days later, CIDRs were removed, while the small estrogen implant was left in place (E; Phase I). Two days later, new CIDRs were inserted and left in place for eight days (E+P; Phase II); this process was repeated for a total of three artificial luteal phases. Mean LH levels were similar between respective $\mathrm{E}+\mathrm{P}$ and $\mathrm{E}$ periods for the second and third artificial phases by ANOVA with repeated measures and Dunnett's test (different letters over bars indicate statistically difference means; $\mathrm{p}<0.05)$. 
Figure 2.1.

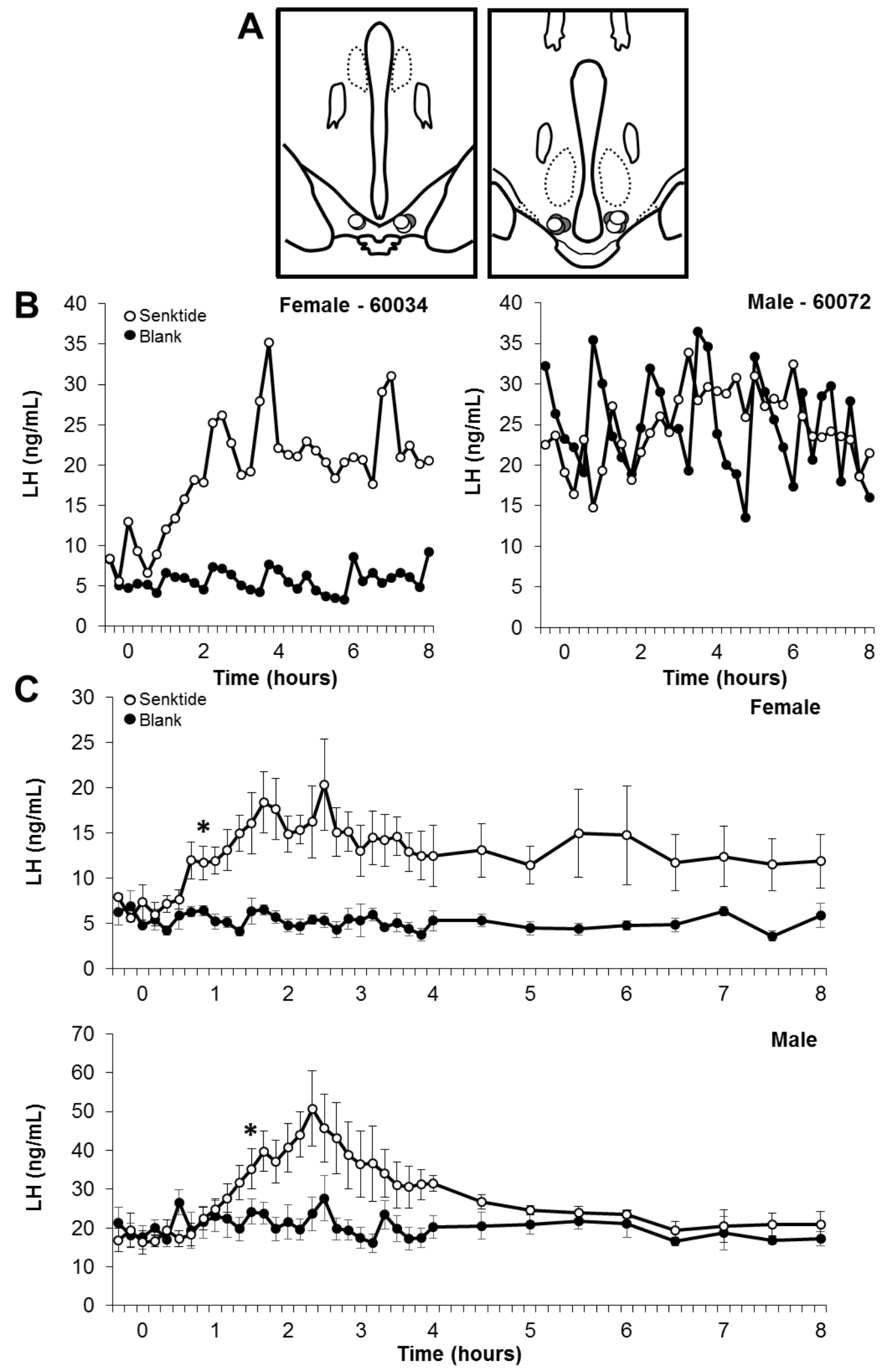


Figure 2.2.
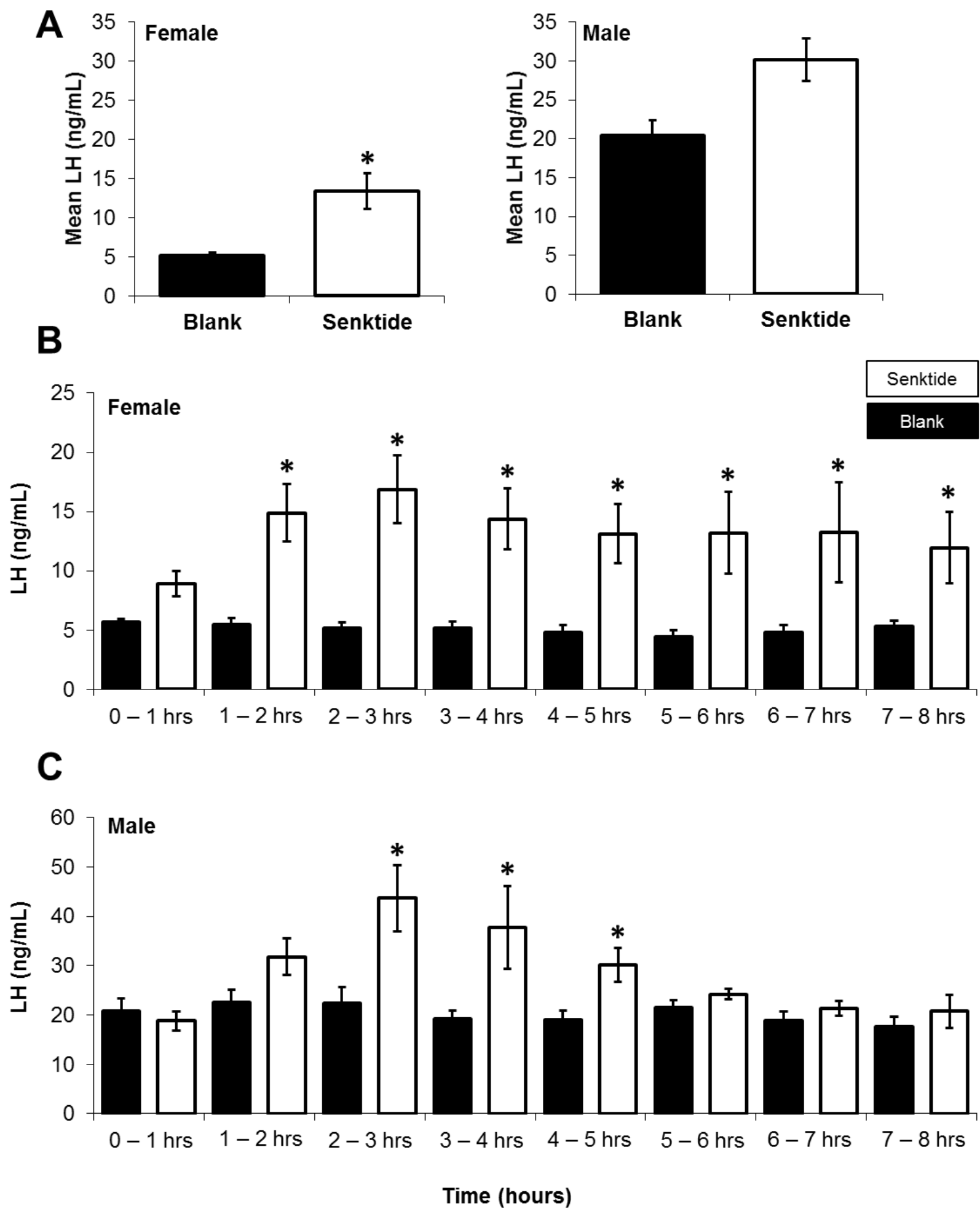

Figure 2.3. 
POA
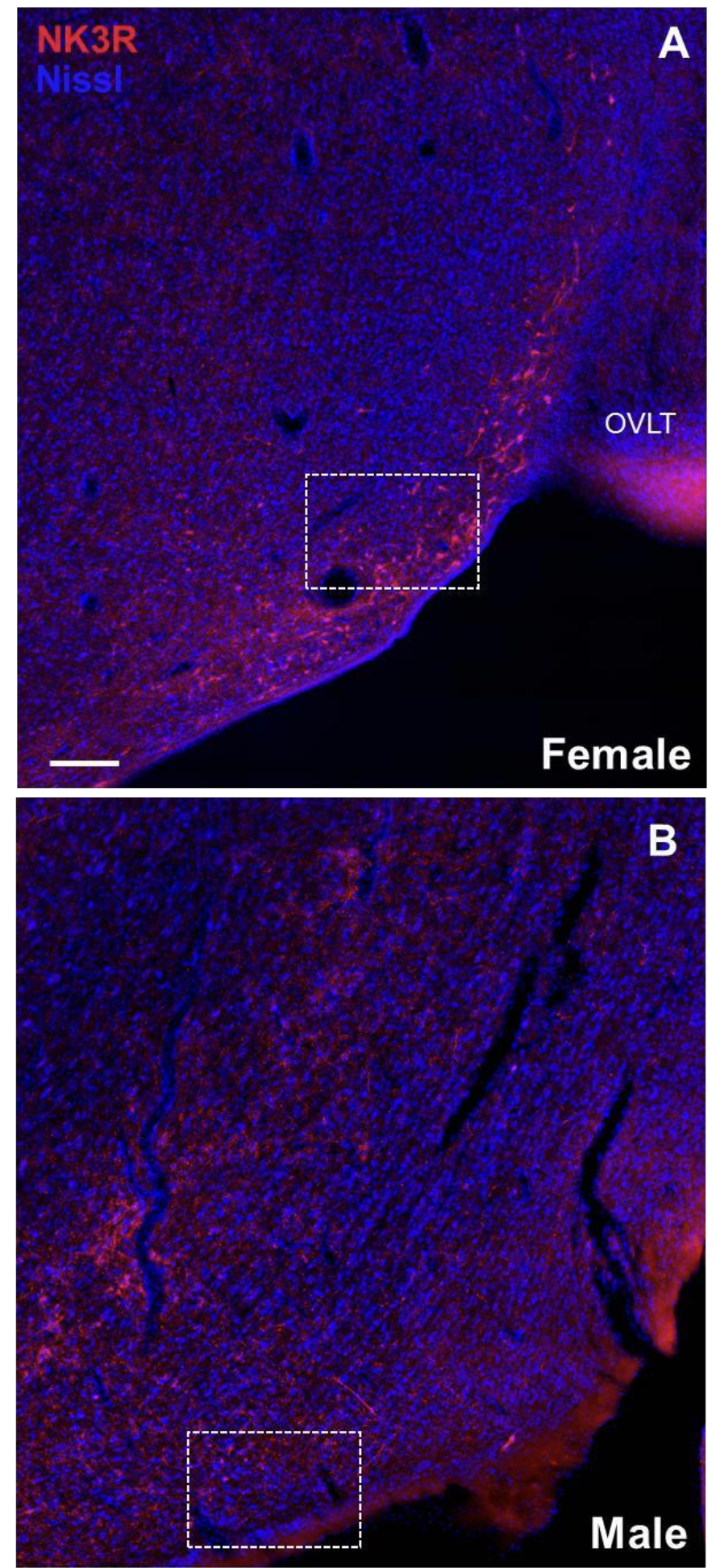
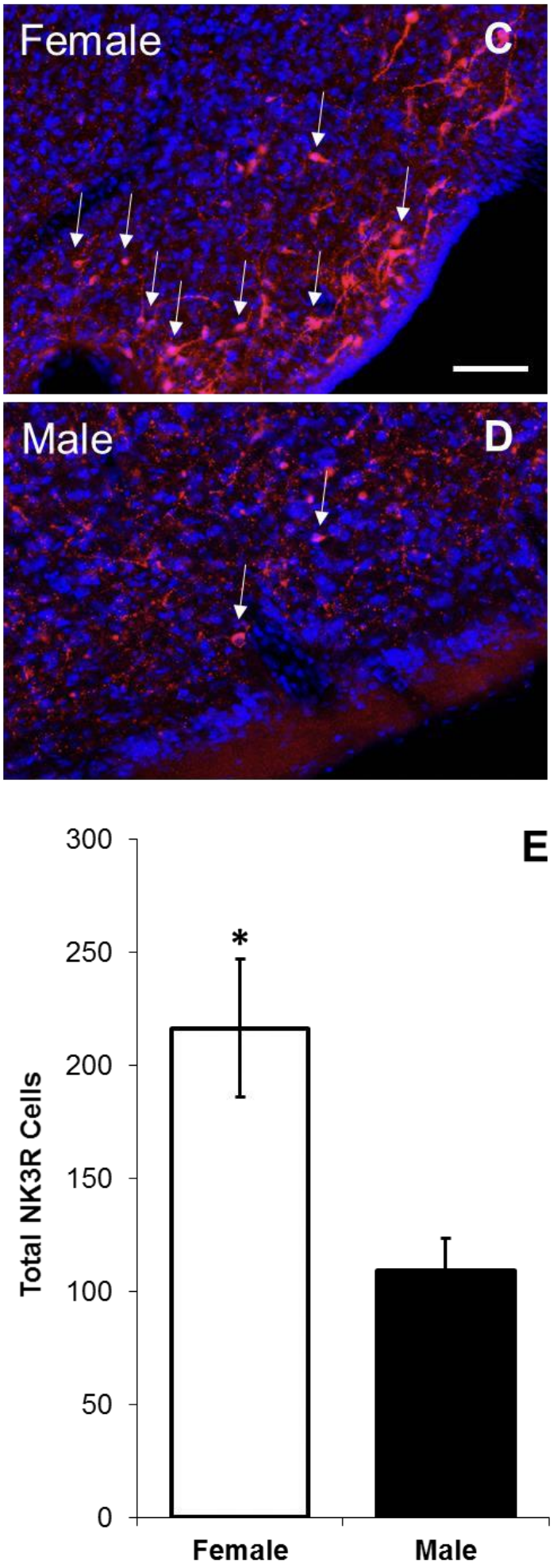
Figure 2.4.

\section{RCh}

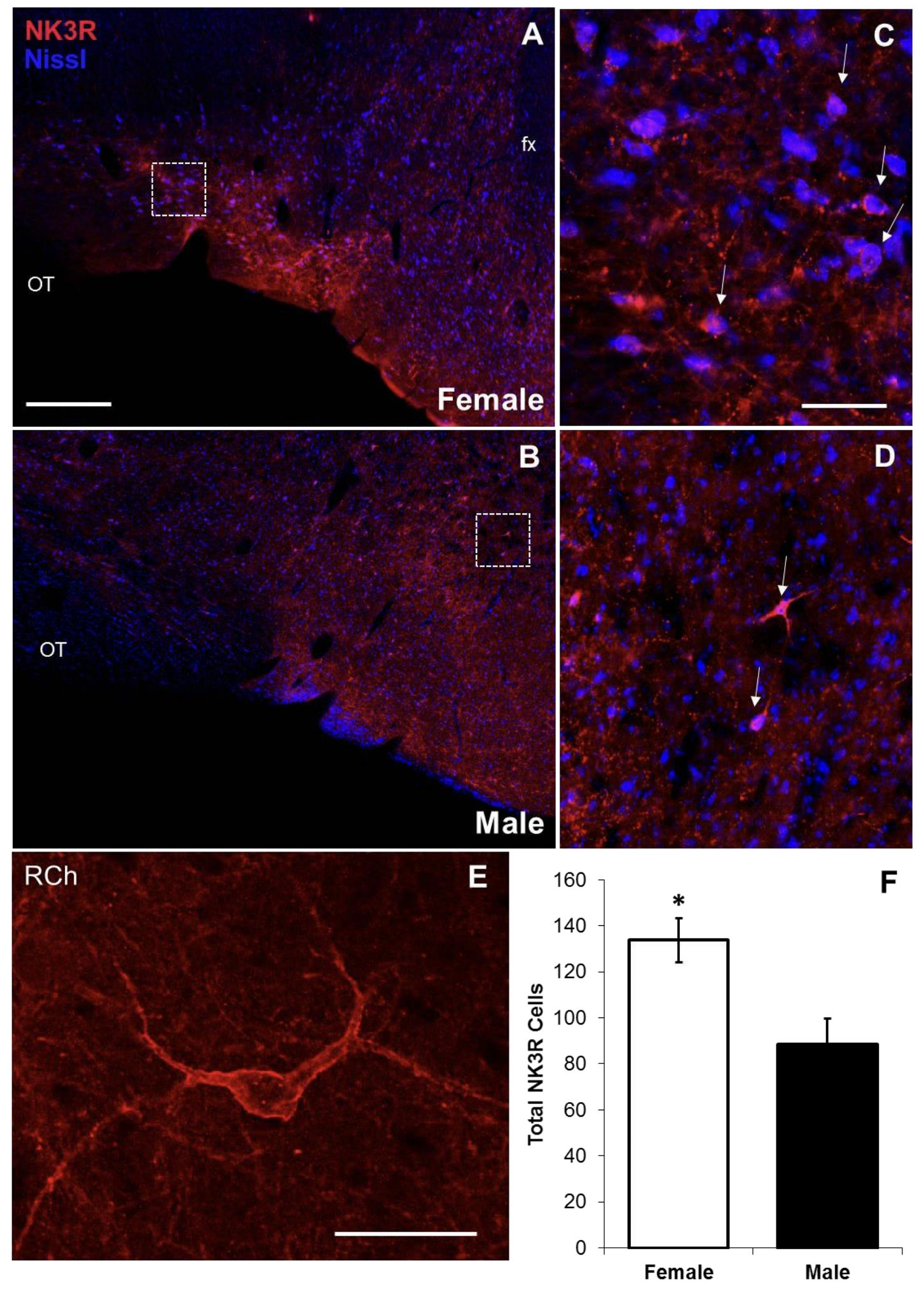


Figure 2.5.

NKB

NissI
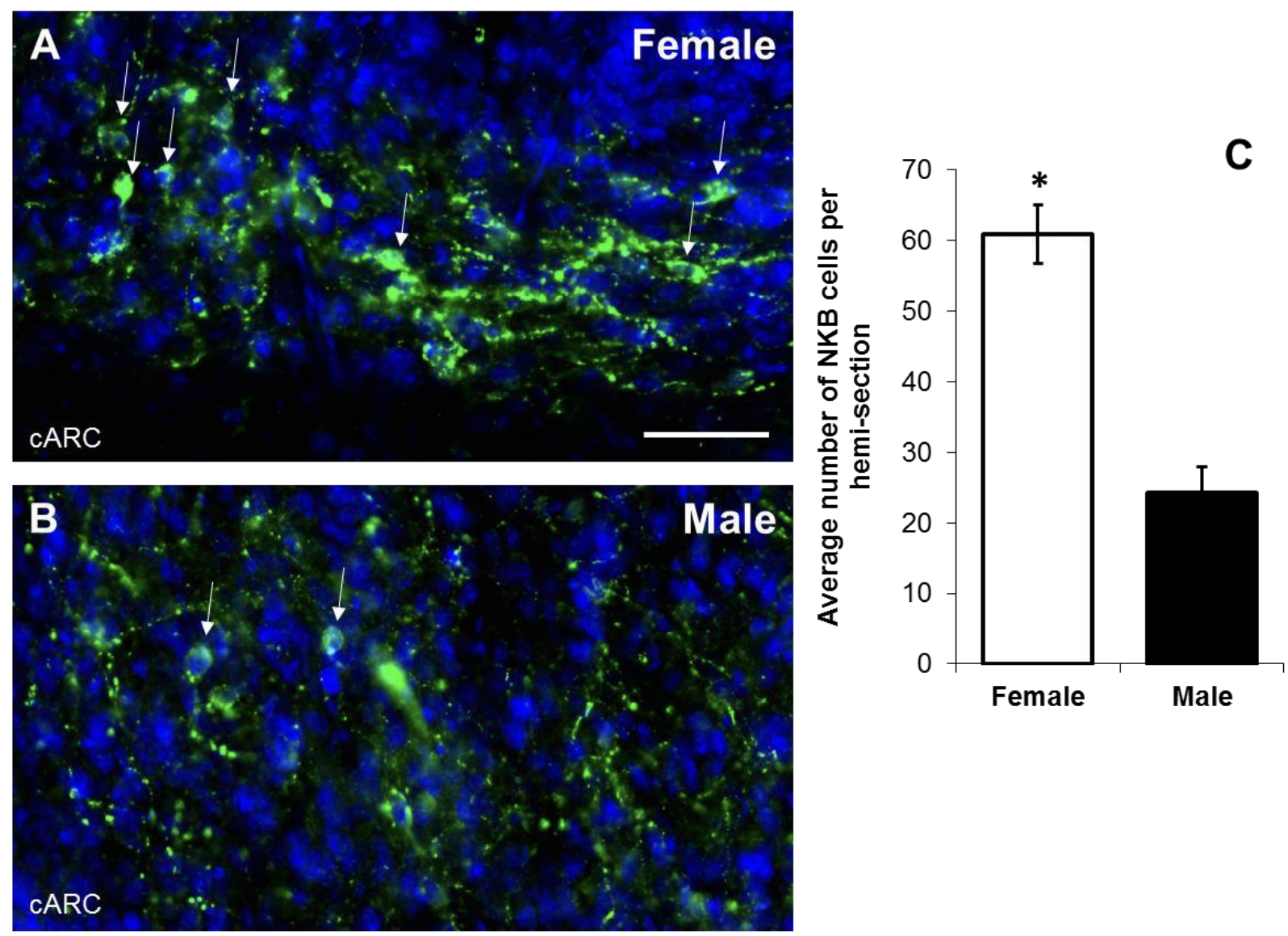
Figure 2.6.

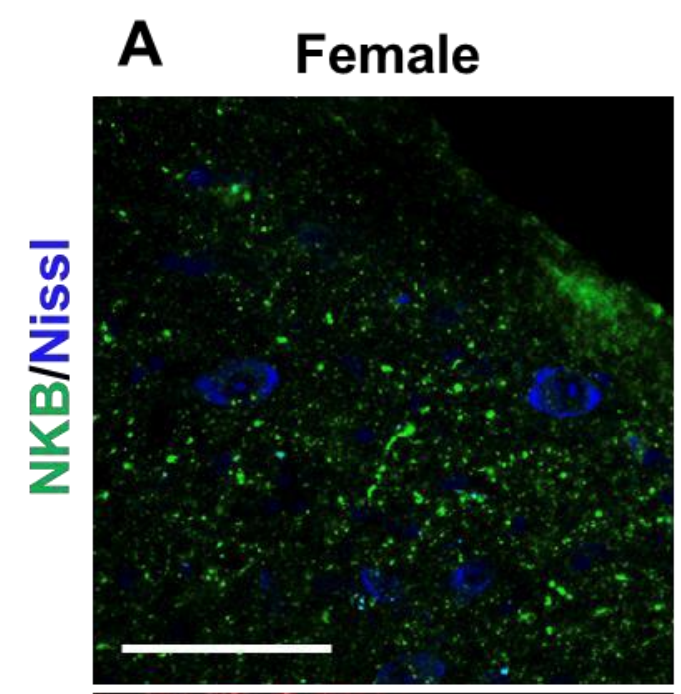

B Male
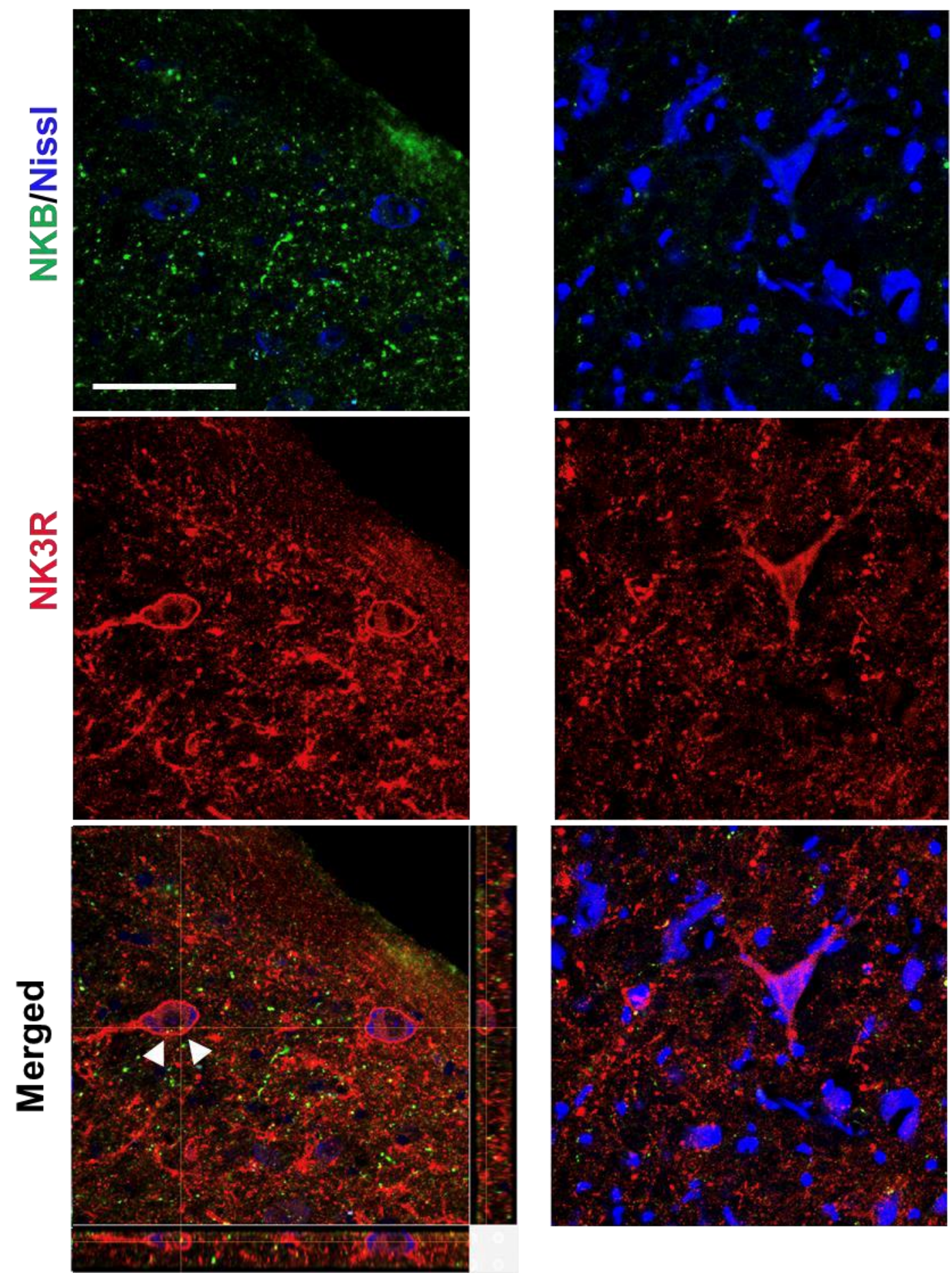
Supplemental Figure 2.1.

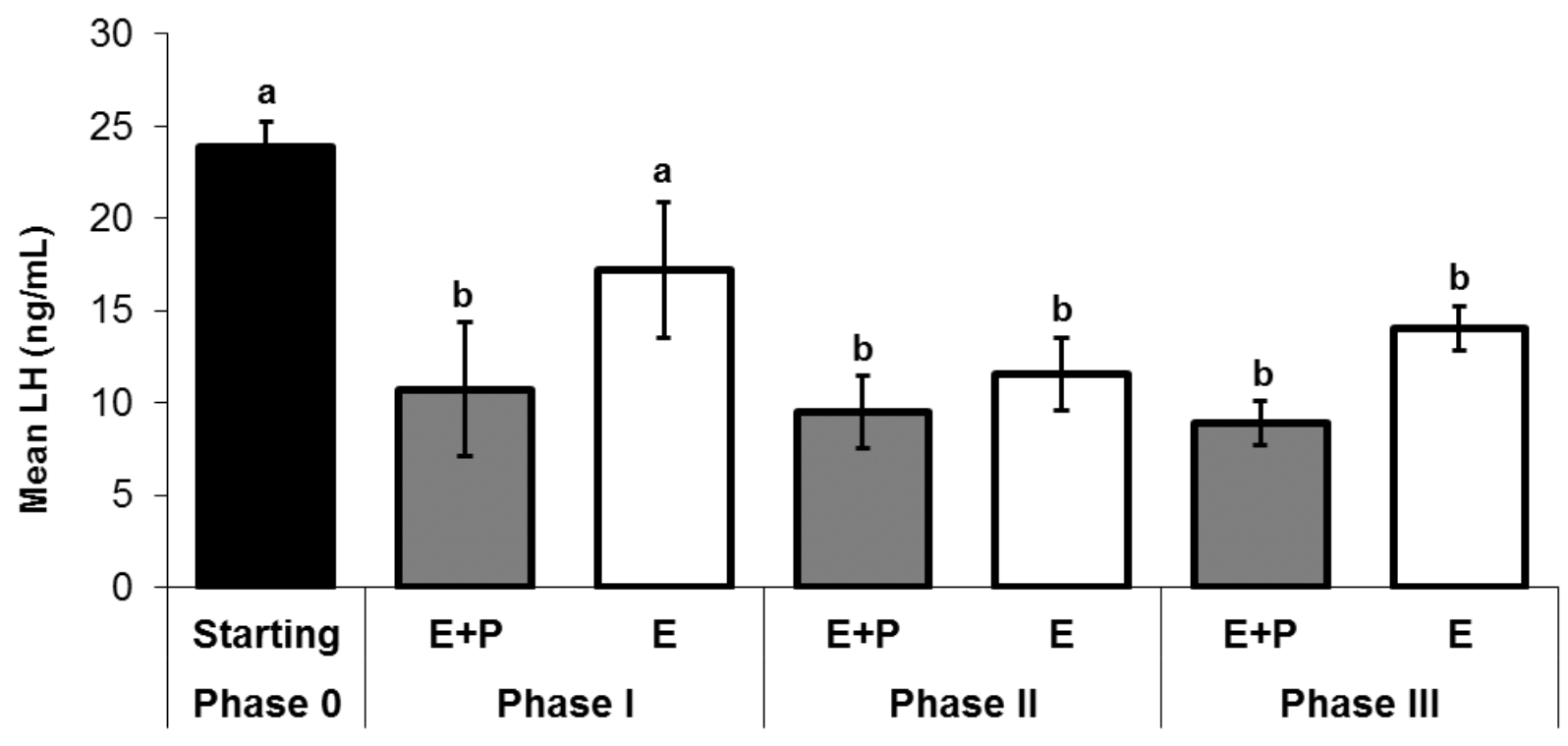

Steroid Treatment 
Morphological and Functional Evidence of Sexual Dimorphism in the Retrochiasmatic Area Population of NK3R-containing Neurons in Sheep

\section{CHAPTER III}

Morphological Implications of Sexual Dimorphism in the Expression of Hypothalamic Kisspeptin and NK3R Neurons 
Morphological Implications of Sexual Dimorphism in the Expression of Hypothalamic Kisspeptin and NK3R Neurons

Justin A. Lopez, Makayla Metzger², Michelle N. Bedenbaugh, Ashley N. Lindo, Elizabeth C. Bowdridge, Stanley M. Hileman, Robert L. Goodman

Department of Physiology and Pharmacology, West Virginia University, Morgantown, WV

${ }^{2}$ Department of Biology, Fairmont State University, Fairmont, WV

Abbreviated Title: Sexual Dimorphism in the Ovine Retrochiasmatic Area

Key Terms: GnRH, NK3R, kisspeptin, sexual dimorphism, reproduction, hypothalamus, sheep

Corresponding author and person to whom reprint requests should be addressed:

Robert Goodman, Ph.D.

PO Box 9229

Department of Physiology and Pharmacology

West Virginia University

Morgantown, WV 26505

Phone: 304-293-1496

Email: rgoodman@hsc.wvu.edu

Disclosure statement: The authors have nothing to disclose 


\section{Abstract:}

The neuropeptides neurokinin $\mathrm{B}(\mathrm{NKB})$ and kisspeptin are critical for fertility in humans and potent stimulators of gonadotropin-releasing hormone (GnRH) and luteinizing hormone (LH) secretion in primates and sheep. We previously obtained evidence that NKB actions in the retrochiasmatic area $(\mathrm{RCh})$, acting via kisspeptin release from kisspeptin neurons in the arcuate nucleus (ARC), are important for the LH surge in sheep. One important characteristic of the LH surge in many species is that it is sexually dimorphic. We demonstrated sexual dimorphism in NK3R-NKB signaling in the preoptic are (POA), RCh, and ARC by comparing tissue from wethers and ovariectomized females. In this study, we extended that work to determine if a neuroanatomical basis exists for this sexual dimorphism in acutely gonadectomized animals by characterizing sex differences in expression of NK3R-, NKB-, and kisspeptin-containing neurons the hypothalamus. To normalize steroid milieu, rams and ewes $(9-10$ months, $n=5 /$ group $)$ of a similar age were gonadectomized and treated with estradiol and progesterone (CIDR) implants that mimicked luteal phase concentrations of these steroids. After one (female) and two (male) artificial luteal phases, CIDRs were removed and LH surge-inducing levels of estradiol were administered via subcutaneous implants. Animals were sacrificed the following day and hypothalamic blocks were removed for immunohistochemical and microscopic analysis. In the $\mathrm{ARC}$, the total number of $\mathrm{NKB}$ and kisspeptin neurons were higher in females than males, but no difference was observed in the percentage of NKB or kisspeptin cells that colocalized with NK3R. There was no difference between the number of NK3R-containing neurons in the POA between females and males, however, a significantly greater number of NK3R-ir cells in the RCh was observed in females. Furthermore, the number of NKB inputs to NK3R-containing cells in the 
RCh was greater in females compared to males. These data provide evidence for a sexual dimorphism in the neuroanatomical basis for the LH surge and indicate that the sexual dimorphism in ARC kisspeptin neurons is due to the organizational actions of gonadal steroids. 


\section{Introduction:}

The neuroendocrine pathways that control ovulation in females have been the subject of intense investigation over the last fifty years (1-5). High levels of estradiol produced by the maturing follicle(s) act to induce a GnRH surge that in turn elicits a corresponding surge of LH, which then causes ovulation. The molecular and neural mechanisms that mediate the interplay between estrogen and GnRH are still not fully understood. Because GnRH neurons are devoid of estrogen receptor alpha $(\mathrm{ER} \alpha)(6)$, the receptor subtype whereby estrogen exerts its effects, intermediary neurons must participate in this process.

The role of kisspeptin in controlling GnRH secretion has been extensively examined since kisspeptin signaling was shown to be critical for fertility in humans $(7,8)$ and mice (8). Importantly, kisspeptin neurons express ER $\alpha$ in numerous species (9), including sheep (10), supporting the likelihood of a direct effect of estrogen on these neurons. Recently, it has been demonstrated that a population of kisspeptin neurons in the rostral periventricular area of the third ventricle mediate the surge-inducing, positive feedback effects of estrogen in female rodents $(2,11)$. In sheep, it appears that kisspeptin neurons in both the arcuate (ARC) and preoptic area (POA) participate in the positive feedback effects of estrogen (12,13). A high percentage of kisspeptin neurons located in the ARC, but not in the POA, co-express neurokinin B (NKB) and dynorphin (14) and were thus given the name "KNDy neurons."

Like kisspeptin, mutations in NKB or its cognate receptor, neurokinin receptor 3 (NK3R), preclude pubertal development and lead to hypogonadotropic hypogonadism in humans (15). We have 
previously demonstrated that senktide, an NK3R agonist, acts in the retrochiasmatic area (RCh) of the ovine hypothalamus to elicit a surge-like increase in LH $(16,17)$. Furthermore, pharmacologic blockade of NK3R signaling within the RCh reduced the amplitude of the LH surge by approximately $50 \%$ (17). This finding demonstrates that NK3R activation in the $\mathrm{RCh}$ is essential for full expression of the preovulatory LH surge. Interestingly, administration of microimplants containing senktide into the $\mathrm{RCh}$ induced an increase in c-Fos expression in kisspeptin neurons located in the ARC (18). Because neurons in the RCh project directly to KNDy neurons (18), we propose that NK3R neurons in the RCh innervate KNDy neurons in the ARC and provide a circuit by which $\mathrm{NKB}$ acts in the RCh to stimulate kisspeptin release, culminating in the GnRH and LH surge in ewes.

While the LH surge is critical for ovulation in females, it typically does not occur in normal males in many species, including rodents (19), sheep (20), and humans (21). Exogenous estrogen treatment, whether alone or preceded by progestin, readily stimulates surge-like secretion of LH in ovariectomized ewes, but not in castrated rams (22). This lack of responsiveness to high levels of estrogen in rams is likely due to exposure to testosterone during critical developmental periods in utero; leading to differentiation of neural systems critical for the LH surge $(23,24)$. Adult rams have lower numbers of kisspeptin neurons in the POA and KNDy neurons in the ARC compared to females (25), but these neurons contain ER $\alpha$ (26) and progesterone receptors (25) in both sexes, indicating they still have the ability to respond to steroid feedback. Moreover, these differences in kisspeptin expression are not seen in females that were treated prenatally with androgens $(25,27)$ and could thus reflect differences in steroid negative feedback between gonadally-intact males and females. Furthermore, marked sex differences are observed between female and male (wethers) 
lambs, including fewer NK3R-positive cell numbers in, and NKB inputs to, the RCh (Chapter 2). These results support the proposal that organizational effects of steroids result in a combined reduction in ligand and receptor components of KNDy/NK3R signaling. However, differences between long-term castrated males (wethers) and short-term ovariectomized (OVX) females might also account for some of these differences.

This study was designed to determine if sexual dimorphism exists in the RCh and ARC of acutely gonadectomized male and female sheep. To test this hypothesis we compared NK3R, NKB, and kisspeptin expression throughout the hypothalamus in male and female lambs during administration of surge-inducing levels of estrogen. To minimize sex differences in endogenous steroid concentrations, all studies were carried out in gonadectomized lambs that were treated with estradiol and progesterone implants to produce "artificial" luteal and/or follicular phases (27-29). This design also allowed us to determine if sexual dimorphism in NK3R, NKB, and kisspeptin expression is a result of organization or activational (direct effects in adults) actions of sex steroids.

\section{Material and Methods:}

\section{Animals:}

Blackface ewe- and ram-lambs born in February or March were moved from pasture to a quarantine area where they were fed Timothy Pellets (Standlee Hay Company, Inc., 22349 Kimberly Road, Kimberly, ID) and Triple Crown Complete Pellets (Triple Crown, 315 Lake Street East, Wayzata, MN) for 2 weeks. They were then moved indoors to acclimate to housing within 
the facility for at least one week before surgeries. Once indoors, sheep were allowed free access to water and mineral blocks and were fed twice daily with Timothy Pellets and Triple Crown to maintain body weight. Animals were maintained in a light- and temperature-controlled facility with the internal lighting environment adjusted to mimic natural changes in day-length. Experiments were performed during the breeding season (December), when animals were 9 to 10 months of age. All procedures were approved by the West Virginia University Animal Care and Use Committee and were performed in accordance with the National Institutes of Health guidelines for the care and use of research animals.

\section{General Methods:}

\section{Surgeries}

Ovariectomies (OVX) were performed under aseptic conditions. Animals were first anaesthetized by i.v. injection of ketamine $(7 \mathrm{mg} / \mathrm{kg})$ and midazolam $(0.3 \mathrm{mg} / \mathrm{kg})$ and then maintained on $2 \%$ to $5 \%$ isoflurane in oxygen. Ovarian vasculature was ligated, and the ovaries were removed via a mid-ventral incision. Castrations (CAST) were performed using the local anesthetic, bupivacaine. Rams were first injected with bupivacaine into each spermatic cord. The distal third of the scrotal sac was removed using a scalpel and connective tissue was dissected from each spermatic cord to visualize the vessels. These vessels were crushed with an emasculator (pressure applied for $2-4$ minutes), the vessels were tied off with a transfixing ligature proximal to the emasculator. The vessels were then cut distal the emasculator, and the testes and emasculators were removed. The castration site was sprayed with Blu-Kote antibacterial spray and left open to drain. Carprofen and 
ampicillin were immediately given to animals and Butorphanol (0.05 mg/kg SQ) or Banamine (2 $\mathrm{mg} / \mathrm{kg}$ IV) were given as needed to alleviate pain. All pre- and post-operative drugs were acquired from Patterson Veterinary (Bessemer, AL).

\section{Steroid replacement and blood sampling procedures}

We used the following well-described $(27,29-31)$ steroid replacement model in both males and females to mimic patterns of ovarian hormones seen during the ovarian cycle: 1) luteal phase levels of estradiol were produced by subcutaneous (sc) insertion a single 1-cm long SILASTIC implant (inner diameter $0.34 \mathrm{~cm}$, outer diameter $0.46 \mathrm{~cm}$; Dow Corning Corp., Midland, MI, USA) containing estradiol; 2) follicular phase levels of estradiol were approximated with four, 3-cm long SILASTIC estradiol implants; and 3) luteal phase progesterone patterns were achieved by inserting 2 Controlled Internal Drug Release (CIDR) devices (Zoetis, Parsippany, NJ) sc and leaving these in place for 10-14 days. Previous studies in ewes demonstrated that sc implantation of CIDRs resulted in levels of plasma progesterone that were similar to vaginally inserted CIDRs (27-29).

Blood samples (3-4 ml) were collected by venipuncture, placed in heparinized tubes and plasma was stored at $-20^{\circ} \mathrm{C}$ until assayed for $\mathrm{LH}$.

Administration of surge-inducing levels of estrogen to male and female gonadectomized lambs 
We first confirmed that there was a sexual dimorphism in estrogen positive feedback in these sheep. Both males and females were treated with estradiol and progesterone (CIDR) implants, as described above, that mimicked luteal phase concentrations of these steroids (30). Young male (n $=5)$ and female $(\mathrm{n}=5)$ sheep at 9 to 10 months of age received one (females) and two (males) artificial luteal phases before the administration of surge-inducing levels of estrogen; males received an additional artificial luteal phase to ensure that LH was suppressed to a level similar to females. On the eighth day of the first (females) and second (males) artificial luteal phase, CIDRs were removed and the following day, four 3-cm long implants containing estradiol were inserted. In order to encompass the entire LH surge, blood samples were collected every 4 hours for 40 hours to assess LH concentrations.

\section{Tissue collection for comparison of NK3R, NKB, and kisspeptin expression between males and females}

We next used these same animals to determine whether differences exist between males and females in NK3R-containing cell populations and/or NKB- and kisspeptin-containing neurons. At the end of the previous experiment, the four long estradiol implants were removed and two new CIDRs inserted. Eight days later, blood samples were collected every 12 minutes for 4 hours to assess LH concentration in the presence of luteal phase levels of progesterone (P). After sampling, CIDRs were removed and the following day, blood samples were collected every 12 minutes for 1 hour to assess LH concentrations in the presence of follicular phase levels of estradiol (E). After

sampling, four 3-cm long implants containing estradiol were inserted. Approximately 18 to 20 hours later, animals were euthanized and tissue blocks were obtained as described below. Blood 
samples were collected every 12 min for 1 hour just before tissue collection to assess $\mathrm{LH}$ concentration in the presence of surge-inducing levels of estradiol (EE).

\section{Tissue collection:}

Hypothalamic tissue blocks were collected for immunohistochemical analysis as previously described (31). Briefly, animals were treated with heparin (20,000 U) 10 minutes before and at the time of euthanasia, which was accomplished by an intravenous overdose of sodium pentobarbital (8 to $12 \mathrm{~mL}$, Euthasol; Patterson Veterinary, Bessemer, AL). Once respiration stopped and there was no eye-blink reflex, the animal was exsanguinated by cutting the carotids, and the head rapidly removed and perfused via the carotid arteries with $4 \mathrm{~L}$ of a solution containing $4 \%$ paraformaldehyde in $0.1 \mathrm{M}$ phosphate buffer (PB) with $0.1 \%$ sodium nitrite. Tissue blocks containing the POA and hypothalamus were removed and stored overnight in the paraformaldehyde solution at $4^{\circ} \mathrm{C}$. The following day, blocks were transferred to a solution containing $20 \%$ sucrose in $0.1 \mathrm{M} \mathrm{PB}$ and stored at $4^{\circ} \mathrm{C}$. A microtome with a freezing stage was used to section blocks in $45-\mu \mathrm{m}$ increments and 10 parallel series of sections (450 $\mu \mathrm{m}$ apart) were stored in cryoprotectant $(32)$ at $-20^{\circ} \mathrm{C}$.

\section{Immunohistochemistry:}

For detection of NK3R, NKB, and kisspeptin, dual-label immunohistochemistry was performed on a complete series of free-floating hemi-sections throughout the hypothalamus from each animal. All washes were performed at room temperature under gentle agitation with phosphate buffered 
saline (PBS). Sections were rinsed 4 times for 5 minutes between incubations unless noted otherwise. On the first day, tissue sections were rinsed thoroughly 12 times for 15 minutes each rinse. After PBS washes, tissue sections were incubated for 1 hour in $1 \% \mathrm{H}_{2} \mathrm{O}_{2}$ for 10 minutes, rinsed, and incubated in 20\% normal goat serum (NGS; Jackson Immunoresearch, West Groove, PA) in PBS containing $0.4 \%$ triton $\mathrm{X}-100$ before overnight incubation with rabbit anti-NKB (dilution 1:5,000 in 4\% NGS; Phoenix, Catalog \#H-026-06, Lot 01297-2) or rabbit anti-kisspeptin (dilution 1:50,000 in 4\% NGS; Caraty: AC566). On the second day, sections were rinsed and then incubated in biotinylated goat anti-rabbit immunoglobin (1:500 in 4\% NGS; Vector BA-1000, Lot ZA0520) for 1 hour, followed by ABC-elite (1:500 in PBS; Vector Laboratory Burlingame, CA) for 1 hour. Sections were rinsed again and incubated for 10 minutes in biotinylated tyramine (TSA) (dilution 1:250; Perkin Elmer, Waltham, MA, USA) in PBS containing $3 \% \mathrm{H}_{2} \mathrm{O}_{2}$ per $1 \mathrm{~mL}$ of solution. After rinsing, sections were incubated in DyLight green 488-conjugated to streptavidin (1:100 in PBS; Fisher Scientific) for 30 minutes, followed by rinses and incubation for 1 hour in 4\% NGS. Sections were incubated overnight with rabbit anti-NK3R (dilution 1:1,000 in 4\% NGS; Novus, Catalog \#NB300-102, Lot F1). On the third day, sections were rinsed and then incubated in Alexa555 goat anti-rabbit (dilution 1:100 in 4\% NGS; Life Technologies, Carlsbad, CA, USA) for 30 minutes. Sections were rinsed again before being incubated with Neurotrace 640/600 Deep Red Fluorescent Nissl Stain (1:100 in PBS; Life Technologies; Lot N21483) for 20 minutes. Sections were then rinsed in phosphate buffer (PB), mounted on charged Superfrost slides (Fisher Scientific), cover-slipped using Gelvatol and stored in the dark at $4{ }^{\circ} \mathrm{C}$ until analyzed.

\section{Analysis of NK3R-ir cells in the POA and RCh, NKB-ir and kisspeptin-ir cells in ARC, and NKB/NK3R and kisspeptin/NK3R colocalization in the ARC:}


The total number of NK3R-ir cells in the POA and RCh, and the average number of NKB-ir and kisspeptin-ir cells/section in the ARC were assessed using an upright fluorescent microscope (VS120; Olympus, Tokyo, Japan) with a 20x objective. The total number of NK3R-ir cells represents the sum of cell numbers in three representative POA hemi-sections that included, or were just posterior to, the organum vasculosum of lamaina terminalis. In the RCh, the total number of NK3R-ir cells represents the sum of cell numbers in three representative sections that extended in the lateral direction from the fornix to the medial edge of the optic tract, dorsally from the fornix to the base of the brain and approximately $1.4 \mathrm{~mm}$ (three hemi-sections) posterior to the optic chiasm $(27,33)$. NKB and kisspeptin cell numbers and the percentage that colocalized with NK3R were averaged across $3-4$ hemi-sections containing the middle to caudal ARC per animal (14). All cell counts were made by an observer blinded to treatment groups.

\section{Analysis of NKB-ir close contacts on NK3r-ir neurons in the RCh:}

In order to examine the number of NKB close-contacts onto NK3R-containing neurons in the RCh, images of 10 neurons were captured across at least 2 sections in the RCh for each animal using the confocal microscope with a 60X Oil/1.4 WD $(130 \mu \mathrm{m})$ objective. Confocal Z-stacks of optical sections were taken at $1 \mu \mathrm{m}$ intervals through each neuron. The number of close-contacts onto cell bodies was analyzed using the Nikon software, NIS Elements, and orthogonal views were used to confirm that contacts were touching the cell in all planes. 


\section{Radioimmunoassay:}

Radioimmunoassays for LH were performed as previously described for ovine samples (34). Briefly, LH concentrations were measured in duplicate using $100-200 \mu \mathrm{L}$ of plasma per sample via a double-antibody radioimmunoassay with reagents supplied by the National Hormone and Peptide Program (Torrance, CA, USA). The sensitivity of the assay averaged $0.06 \mathrm{ng} /$ tube, and the intra- and interassay variability were $13.4 \%$ and $14.1 \%$, respectively.

\section{Statistical analysis:}

The total number of NK3R cells in the POA and RCh, the average number of NKB or kisspeptin cells in the ARC, the percentage of NKB or kisspeptin cells that colocalized with NK3R in the ARC, and the average number of NKB contacts onto NK3R-positive cells in the RCh were compared between sexes with independent t-tests. Data are reported as mean \pm SEM. Differences were considered significant when $\mathrm{P}<0.05$.

\section{Results}

Administration of surge-inducing levels of estrogen to male and female gonadectomized lambs

As expected, only females were capable of generating an LH surge after exposure to surgeinducing levels of estrogen. For females, the average peak was $64.1 \pm 7.9 \mathrm{ng} / \mathrm{mL}$ and the average 
time to peak was $23.2 \pm 1.5$ hours post-implantation of four, 3-cm estrogen implants (Fig. 3.1A). Furthermore, and as expected, the mean LH levels for the entire 40-hour sampling period were higher in females compared to males: $14.2 \pm 1.0$ versus $2.9 \pm 0.6$ (Fig. 3.1B).

\section{Are NK3R-containing cell populations throughout POA and RCh sexually dimorphic?}

As expected, mean LH concentrations were higher in females compared to males at the time of tissue collection, when an LH surge was occurring in many females, but no males $(16.1 \pm 8.6$ $\mathrm{ng} / \mathrm{mL}$ vs $2.2 \pm 0.3 \mathrm{ng} / \mathrm{mL}$ ). No differences were observed between sexes when samples were collected during exposure to luteal phase levels of estrogen and progesterone or during exposure to only low levels of estrogen (Fig. 3.2)

In agreement with previous work (33), NK3R-cell populations throughout the POA and hypothalamus appeared morphologically distinct depending on region. NK3R-containing cells presented with morphology similar to what is described in Chapter 2. There was no difference in the number of NK3R-ir cells in the POA (Fig. 3.3A) between sexes (female $151.4 \pm 20.5$ vs male $110.8 \pm 16.3$ cells) but there were more NK3R-ir cell in the RCh (Fig. 3.3B) in females than in males $(81.8 \pm 10.3$ vs $55.6 \pm 7.5$ cells; $\mathrm{p}=0.03)$.

Does sexual dimorphism exist in the population of NKB-ir and kisspeptin-ir cells or the percentage of NKB-ir and kisspeptin-ir cells that contain NK3R in the ARC? 
In agreement with previous work (33), a significantly greater number of NKB neurons was observed within the ARC of females compared to males: $37.5 \pm 4.1$ versus $8.1 \pm 1.1(\mathrm{p}<0.05)$ (Fig. 3.4C). No difference was observed in the percentage of NKB cells that colocalized with NK3R: females $44.6 \pm 2.9 \%$ versus males $34.1 \pm 10.1 \%(\mathrm{p}=0.18)$. Kisspeptin neurons were readily visualized for both sexes in the middle to caudal ARC and presented with parvicellular morphology typical of KNDy neurons (Fig. 3.4A). There was a significantly greater number of kisspeptin cells in the ARC of females compared to males (Fig. 3.4B). NK3R-expressing cells were highly dense in the middle to caudal ARC irrespective of sex. Nearly all kisspeptin cells were contacted by NK3R-positive fibers and a high number of NK3R varicosities were visible in the ARC. The percentage of kisspeptin cells that colocalized with NK3R was similar between sexes: females $16.1 \pm 3.8 \%$ versus males $14.8 \pm 3.5 \%$.

\section{Are NKB projections to the RCh sexually dimorphic?}

As illustrated by representative photomicrographs in Figure 3.5, there was a greater number of NKB-ir inputs to NK3R-containing neurons in the RCh in females than in males $(3.67 \pm 0.76$ contacts/cell vs. $1.05 \pm 0.19$ contacts/cell; $\mathrm{P}=0.02$ ).

\section{Discussion}


In the present study we characterized the expression of NK3R throughout the POA and hypothalamus and NKB inputs to NK3R-containing cells in the RCh of acutely gonadectomized male and female sheep. We also examined kisspeptin and NKB immunoreactivity and the degree of NK3R colocalization with each peptide within the ARC. We demonstrated that NK3R immunoreactivity and the number of NKB inputs per NK3R cell in the RCh, and kisspeptin and $\mathrm{NKB}$ immunoreactivity in the ARC was greater in gonadectomized females compared to males that were both exposed to levels of estradiol sufficient for surge generation in females. In conjunction with data previously reported (Lopez et al., 2018 - Chapter 2), these data provide further evidence for differences within the RCh that may contribute to the sexual dimorphism of the estrogen-induced LH surge in sheep. Thus the RCh and ARC are likely sites of morphological sexual dimorphism associated with the control of GnRH secretion.

As expected, we observed differences in the patterns of LH release between gonadectomized males and females (20). Specifically, only females were capable of generating LH surges after implantation of surge-inducing levels of estradiol. In contrast, no sex differences were observed in LH levels between males and females during exposure to luteal phase levels of estradiol and progesterone or only low levels of estradiol. This contrasts with the data in Chapter 2 and indicates that the sexual dimorphism observed in the RCh and ARC does not correlate with sex differences in steroid negative feedback. As previously mentioned, a major sex difference that exists between males and females is the LH surge, which is programmed largely during gestation in males as a result of the organizational effects of steroids. 
In this study we observed that the total number of NK3R-containing cells in the POA did not differ between sexes after administration of surge-inducing levels of estradiol. This is in contrast to what was observed in Chapter 2 in wethers, but in agreement with what was observed in prenataltestosterone-treated females (27). One simple explanation for this discrepancy is that the prolonged absence of androgens decreased NK3R expression in wethers. However the difference between these two studies reflect the number of NK3R-ir cells observed in females. In the earlier report, the number of NK3R-ir cells in the POA was $216 \pm 30.7$ cells in females compared to $109.5 \pm 14.2$ cells in wethers. In the present report, when tissue was stained using the same protocol as in the previous study, the number of NK3R-ir cells in the POA was $151.4 \pm 20.5$ cells in females compared to $110.8 \pm 16.3$ cells in wethers. This difference in the number of NK3R-ir cells observed in females between studies is potentially due to higher levels of LH observed at the time of tissue collection. In the previous study, the mean LH concentration at the time of tissue collection in females was $78.8 \pm 35.2 \mathrm{ng} / \mathrm{mL}$ compared to $16.1 \pm 8.7 \mathrm{ng} / \mathrm{mL}$ in the current study. In contrast to the POA, the total number of NK3R-containing cells in the RCh was lower in males than females in both studies, indicating that this sexual dimorphism is independent of differences between wethers and acutely-castrated male sheep and thus likely related to estrogen positive feedback. As discussed in Chapter 2, no difference was observed in the number of NK3R-containing cells in prenatal testosterone-treated females compared to control females (27). Thus, lambs born to prenatally testosterone-treated ewes may represent an intermediate neuroanatomical state between those born to non-treated ewes.

The number of kisspeptin cells in the ARC was higher in steroid-treated gonadectomized females compared to males in this study. This is in agreement with earlier reports in adults males (25). In 
contrast, kisspeptin cell numbers in the ARC are not affected by testosterone treatment in utero because androgenized females do not show reduced numbers compared to normal females when tissue is collected during an "artificial follicular phase" (25). The latter observations raise the possibility that the sexual dimorphism seen in gonadally-intact sheep was due to differences in the endogenous hormonal milieu, and not the organizational actions of androgens in utero. Tissue in this study was collected during an artificial follicular phase in both sexes, thus the differences in kisspeptin expression most likely reflect the organizational actions of androgens. There are two possible explanations for the absence of this sexual dimorphism in prenatally androgenized ewes. First, and the simpler explanation, is that more prolonged exposure to androgen in utero may be required. Second, post-natal exposure to estradiol may play a role. Postnatal exposure to ovarian tissue or estradiol (for 2 years) is required for prenatally testosterone-treated females to undergo complete defeminization of the GnRH surge mechanism (29). The possibility exists that during this additional period of "differentiation," postnatal exposure to estrogen, rather than testicular testosterone, within the first few months (or years) of life may influence the KNDy cell population in the ARC.

The observation that the number of NKB cells in the ARC is higher in young females compared to young males is in agreement with previous results in young and adult intact rams $(26,35)$, prenatally testosterone-treated females (27), and the data presented in Chapter 2. There is a discrepancy, however, in the number of neurons observed between the previous study and the current study. In Chapter 2, the number of NKB cells in the ARC was $~ 60$ and 24 cells in females and males, respectively. In the present report, the number of NKB cells was $37.5 \pm 4.1$ cells in females, compared to $8.1 \pm 1.1$ cells in males. As previously discussed with the number of POA 
NK3R-containing cells, this may be due to higher levels of LH observed at the time of tissue collection in the previous report. Furthermore, there is a discrepancy in the number of kisspeptin and NKB neurons observed in the ARC of this study. Since these are both KNDy neurons, the number of cells would be expected to be similar (36). A simple explanation for this observation can be attributed to the sensitivity of the immunofluorescent method used during the immunohistochemical process. For kisspeptin detection, a highly specific and validated (at the dose used herein) antibody was used that was generated by Alain Caraty and colleagues. This antibody is targeted against the C-terminal end of kisspeptin and has been shown to be specific in a number of species by both careful preabsorption controls $(10,14,37)$ and the use of Kiss 1 knockout mice as negative controls (37). Although the NKB antibody used in this study has also been previously validated (36), either this antibody may not be as sensitive as the antibody used for kisspeptin detection or the immunohistochemical protocol was not yet completely optimized, resulting in differences in the levels of detectability in both kisspeptin and NKB. Still, the number of kisspeptin and NKB neurons that coexpressed NK3R in the ARC between experiments was similar: females, $\sim 17$ kisspeptin and NKB cells coexpress NK3R, and males, $\sim 2$ kisspeptin and 3 NKB cells coexpress NK3R.

We observed sex differences in the number of NKB-containing inputs onto NK3R-ir cells in the RCh. The presence of NKB-containing fibers in the RCh is in agreement with previous findings in female sheep (93). Furthermore, and as discussed previously, the number of NKB inputs to NK3R-containing neurons was greater in females compared to wethers after exposure to surgeinducing levels of estrogen, which is similar to what was observed in this study. Thus, NKB innervation of the $\mathrm{RCh}$, and the inputs that $\mathrm{NK} 3 \mathrm{R}$-containing neurons receive in this region, is 
likely controlled by organizational effects of sex steroid during development, rather than activational effects during adulthood. As previously discussed, the origin of these fibers is unknown. In sheep, nearly all NKB-ir neurons are located in the ARC $(60,120)$, and the vast majority of these neurons also contain kisspeptin (62). However, these KNDy neurons do not project to the RCh because few, if any, kisspeptin-ir fibers are seen in this region (194). There is evidence that some cells in the ARC project to the $\mathrm{RCh}$, but these cells did not colocalize with kisspeptin (160). Thus, the source of the NKB inputs seen in the RCh could be either the small number of NKB neurons in the ARC that do not co-express kisspeptin (62) or other NKBproducing cells that cannot be detected by immunohistochemistry because the peptide is rapidly transported to terminals.

The combined decrease in both ligand (kisspeptin or NKB) and receptor (NK3R) signaling found in males may contribute to the sexual dimorphism in the failure of males to produce $\mathrm{GnRH} / \mathrm{LH}$ surges. In conjunction with an earlier report by Lopez et al., 2018, these findings support the hypothesis that the population of NK3R-containing cells in the RCh may be essential for full expression of the LH surge in females (17). These cells are thought to increase $\mathrm{GnRH} / \mathrm{LH}$ secretion during a surge by activating release of kisspeptin from KNDy cells in the ARC (18). Thus, the lower number of $\mathrm{NKB}$ and kisspeptin cells in the ARC of males could also contribute to the sexual dimorphism seen in the inability of males to generate an LH surge.

In summary, we report morphological evidence of sexual dimorphism in NK3R and KNDy signaling in the ovine RCh and ARC, respectively. Based on the observation of fewer NK3Rpositive cells and NKB contacts onto NK3R-containing cells in the RCh, and fewer NKB and 
kisspeptin cells in the ARC of males, we propose that deficiencies in the response to NKB in the $\mathrm{RCh}$, and in the ability of KNDy neurons to respond to a stimulus from the $\mathrm{RCh}$, contribute to the sex-dependent expression of the GnRH/LH surge in sheep.

\section{Acknowledgements}

We thank Miroslav Valent, Gail Sager, and John Connors for technical assistance with radioimmunoassay and animal surgeries. We also thank Drs. Margaret Minch and Jennifer Fridley for veterinary care, Heather Bungard for care of the sheep, and Dr. Al Parlow and the National Hormone and Peptide program for reagents used to measure LH. We also thank Dr. Amanda Ammer for assistance in image analysis and processing.

Image capture and image analysis were performed in the West Virginia University (WVU) Microscope Imaging Facility, which has been supported by the WVU Cancer Institute and NIH Grants P20 RR016440, U54 GM104942, and P20 GM103434.

This work was supported by National Institutes of Health (NIH) Grants R01-HD039916, R01HD082135, and P20GM103434 to the West Virginia IDeA Network for Biomedical Research Excellence.

Disclosure Summary: The authors have nothing to disclose. 


\section{References:}

1. Levine JE. New concepts of the neuroendocrine regulation of gonadotropin surges in rats. Biol. Reprod. 1997;56(2):293-302.

2. Khan AR, Kauffman AS. The role of kisspeptin and RFamide-related peptide-3 neurones in the circadian-timed preovulatory luteinising hormone surge. J. Neuroendocrinol. 2012;24(1):131-143.

3. Plant TM. A comparison of the neuroendocrine mechanisms underlying the initiation of the preovulatory LH surge in the human, Old World monkey and rodent. Front. Neuroendocrinol. 2012;33(2):160-168.

4. Clarke IJ. The preovulatory LH surge. A case of a neuroendocrine switch. Trends Endocrinol. Metab. 1995;6(7):241-247.

5. Goodman RL. Neuroendocrine Control of Gonadotropin Secretion: Comparative Aspects. In: Knobil and Neill's Physiology of Reproduction.; 2015:1537-1574.

6. Lehman MN, Ebling FJP, Moenter SM, Karsch FJ. Distribution of estrogen receptorimmunoreactive cells in the sheep brain. Endocrinology 1993;133(2):876-886.

7. de Roux N, Genin E, Carel J-C, Matsuda F, Chaussain J-L, Milgrom E. Hypogonadotropic hypogonadism due to loss of function of the KiSS1-derived peptide receptor GPR54. Proc. Natl. Acad. Sci. 2003. doi:10.1073/pnas.1834399100.

8. Seminara SB, Messager S, Chatzidaki EE, Thresher RR, Acierno JS, Shagoury JK, Bo-Abbas Y, Kuohung W, Schwinof KM, Hendrick AG, Zahn D, Dixon J, Kaiser UB, Slaugenhaupt SA, Gusella JF, O'Rahilly S, Carlton MBL, Crowley WF, Aparicio SAJR, Colledge WH. The GPR54 Gene as a Regulator of Puberty. Obstet. Gynecol. Surv. 2004. doi:10.1097/00006254-200405000-00020.

9. Lehman MN, Hileman SM, Goodman RL. Neuroanatomy of the kisspeptin signaling system in mammals: Comparative and developmental aspects. Adv. Exp. Med. Biol. 2013;784:27-62.

10. Franceschini I, Lomet D, Cateau M, Delsol G, Tillet Y, Caraty A. Kisspeptin immunoreactive cells of the ovine preoptic area and arcuate nucleus co-express estrogen receptor alpha. Neurosci. Lett. 2006;401(3):225-230.

11. Herbison AE. Estrogen positive feedback to gonadotropin-releasing hormone $(\mathrm{GnRH})$ neurons in the rodent: The case for the rostral periventricular area of the third ventricle (RP3V). Brain Res. Rev. 2008;57(2):277-287.

12. Smith JT, Li Q, Pereira a., Clarke IJ. Kisspeptin neurons in the ovine arcuate nucleus and preoptic area are involved in the preovulatory luteinizing hormone surge.

Endocrinology 2009;150(12):5530-5538.

13. Merkley CM, Porter KL, Coolen LM, Hileman SM, Billings HJ, Drews S, Goodman RL, Lehman MN. KNDy (kisspeptin/neurokinin B/dynorphin) neurons are activated during both pulsatile and surge secretion of LH in the ewe. Endocrinology 2012;153(11):5406-5414.

14. Goodman RL, Lehman MN, Smith JT, Coolen LM, De Oliveira CVR, Jafarzadehshirazi MR, Pereira A, Iqbal J, Caraty A, Ciofi P, Clarke IJ. Kisspeptin neurons in the arcuate nucleus of the ewe express both dynorphin A and neurokinin B. Endocrinology 2007. doi:10.1210/en.2007-0961.

15. Topaloglu a K, Reimann F, Guclu M, Yalin AS, Kotan LD, Porter KM, Serin A, Mungan NO, Cook JR, Ozbek MN, Imamoglu S, Akalin NS, Yuksel B, O'Rahilly S, 
Semple RK. TAC3 and TACR3 mutations in familial hypogonadotropic hypogonadism reveal a key role for Neurokinin B in the central control of reproduction. Nat. Genet. 2009;41(3):354-358.

16. Billings HJ, Connors JM, Altman SN, Hileman SM, Holaskova I, Lehman MN, McManus CJ, Nestor CC, Jacobs BH, Goodman RL. Neurokinin B acts via the neurokinin-3 receptor in the retrochiasmatic area to stimulate luteinizing hormone secretion in sheep. Endocrinology 2010;151(8):3836-3846.

17. Porter KL, Hileman SM, Hardy SL, Nestor CC, Lehman MN, Goodman RL. Neurokinin-3 Receptor Activation in the Retrochiasmatic Area is Essential for the Full Preovulatory LH Surge in Ewes. J. Neuroendocrinol. 2014. doi:10.1111/jne.12180.

18. Grachev P, Porter KL, Coolen LM, McCosh RB, Connors JM, Hileman SM, Lehman MN, Goodman RL. Surge-Like Luteinising Hormone Secretion Induced by Retrochiasmatic Area NK3R Activation is Mediated Primarily by Arcuate Kisspeptin Neurones in the Ewe. J. Neuroendocrinol. 2016;28(6). doi:10.1111/jne.12393.

19. Corbier P. Sexual differentiation of positive feedback: Effect of hour of castration at birth on estradiol-induced luteinizing hormone secretion in immature male rats. Endocrinology 1985;116(1):142-147.

20. Herbosa CG, Dahl GE, Evans NP, Pelt J, Wood RI, Foster DL. Sexual differentiation of the surge mode of gonadotropin secretion: Prenatal androgens abolish the gonadotropin-releasing hormone surge in the sheep. J. Neuroendocrinol. 1996;8(8):627633.

21. VAN LOOK PFA, HUNTER WM, CORKER CS, BAIRD DT. FAILURE OF POSITIVE FEEDBACK IN NORMAL MEN AND SUBJECTS WITH TESTICULAR FEMINIZATION. Clin. Endocrinol. (Oxf). 1977;7(5):353-366.

22. Stormshak F, Estill CT, Resko JA, Roselli CE. Changes in LH secretion in response to an estradiol challenge in male- and female-oriented rams and in ewes. Reproduction 2008;135(5):733-738.

23. Wood RI, Foster DL. Sexual differentiation of reproductive neuroendocrine function in sheep. Rev. Reprod. 1998;3(2):130-140.

24. Foster DL, Padmanabhan V, Wood RI, Robinson JE. Sexual differentiation of the neuroendocrine control of gonadotrophin secretion: concepts derived from sheep models. Reprod. Suppl. 2002;59:83-99.

25. Cheng G. Coolen LM. Padmanabhan V. Goodman RL. Lehman M. The kisspeptin/neurokinin B/dynorphin (KNDy) cell population of the arcuate nucleus: sex differences and effects of prenatal. Endocrinology 2010;151(1):301-311.

26. Goubillon ML, Forsdike RA, Robinson JE, Ciofi P, Caraty A, Herbison AE. Identification of neurokinin B-expressing neurons as an highly estrogen-receptive, sexually dimorphic cell group in the ovine arcuate nucleus. Endocrinology 2000;141(11):4218-4225.

27. Ahn T, Fergani C, Coolen LM, Padmanabhan V, Lehman MN. Prenatal Testosterone Excess Decreases Neurokinin 3 Receptor Immunoreactivity within the Arcuate Nucleus KNDy Cell Population. J. Neuroendocrinol. 2015;27(2):100-110.

28. Robinson JE, Forsdike RA, Taylor JA. In utero exposure of female lambs to testosterone reduces the sensitivity of the gonadotropin-releasing hormone neuronal network to inhibition by progesterone. Endocrinology 1999;140(12):5797-5805.

29. Jackson LM, Mytinger A, Roberts EK, Lee TM, Foster DL, Padmanabhan V, Jansen 
HT. Developmental programming: Postnatal steroids complete prenatal steroid actions to differentially organize the GnRH surge mechanism and reproductive behavior in female sheep. Endocrinology 2013;154(4):1612-1623.

30. Skinner DC, Harris TG, Evans NP. Duration and amplitude of the luteal phase progesterone increment times the estradiol-induced luteinizing hormone surge in ewes. Biol. Reprod. 2000;63(4):1135-42.

31. McCosh RB, Szeligo BM, Bedenbaugh MN, Lopez JA, Hardy SL, Hileman SM, Lehman MN, Goodman RL. Evidence that endogenous somatostatin inhibits episodic, but not surge, secretion of LH in female sheep. Endocrinology 2017;158(6):1827-1837.

32. Watson RE, Wiegand SJ, Clough RW, Hoffman GE. Use of cryoprotectant to maintain long-term peptide immunoreactivity and tissue morphology. Peptides 1986;7(1):155-159.

33. Amstalden M, Coolen LM, Hemmerle AM, Billings HJ, Connors JM, Goodman RL, Lehman MN. Neurokinin 3 receptor immunoreactivity in the septal region, preoptic area and hypothalamus of the female sheep: Colocalisation in neurokinin B cells of the arcuate nucleus but not in gonadotrophin-releasing hormone neurones. J. Neuroendocrinol. 2010;22(1):1-12.

34. Goodman RL, Coolen LM, Anderson GM, Hardy SL, Valent M, Connors JM, Fitzgerald ME, Lehman MN. Evidence that dynorphin plays a major role in mediating progesterone negative feedback on gonadotropin-releasing hormone neurons in sheep. Endocrinology 2004;145(6):2959-2967.

35. Nestor CC, Briscoe AMS, Davis SM, Valent M, Goodman RL, Hileman SM. Evidence of a role for kisspeptin and neurokinin B in puberty of female sheep. Endocrinology 2012;153(6):2756-2765.

36. Cheng G, Coolen LM, Padmanabhan V, Goodman RL, Lehman MN. The kisspeptin/neurokinin B/dynorphin (KNDy) cell population of the arcuate nucleus: Sex differences and effects of prenatal testosterone in sheep. Endocrinology 2010;151(1):301311.

37. Clarkson J, d'Anglemont de Tassigny X, Colledge WH, Caraty A, Herbison AE. Distribution of kisspeptin neurones in the adult female mouse brain. J. Neuroendocrinol. 2009. doi:10.1111/j.1365-2826.2009.01892.x. 


\section{Figure Legends}

Figure 3.1. Representative LH concentrations over time for a female sheep compared to that of a male sheep after the administration of estrogen implants. The mean LH concentration (ng/mL) for the entire 40-hour sampling period is shown to the right. Asterisk indicates a significant difference from males $(\mathrm{p}<0.05)$.

Figure 3.2. Mean LH concentrations for female and male sheep during exposure to luteal phase levels of estrogen and progesterone (P), only low levels of estrogen (E), or surge-inducing levels of estrogen (EE). The high variability in the EE group is due to differences in the start of LH surges among individual ewes. Asterisk indicates a significant difference from males $(\mathrm{p}<0.05)$.

Figure 3.3. NK3R immunoreactivity in the POA and RCh of female and male sheep. Bar graphs compare the total number of NK3R-ir neurons in the POA and RCh of female and male sheep during exposure of surge-inducing levels of estradiol ( $\mathrm{p}<0.05^{*}$ vs male).

Figure 3.4. (A) Representative photomicrographs from a female (top row) and male (bottom row) sheep showing kisspeptin and Neurotrace (first; scale bar $=200 \mathrm{um}$ ), NK3R and Neurotrace (second), merged images (third), followed by a high magnification view of the area indicated by the white boxes (fourth; scale bar $=50 \mathrm{um}$ ). Co-localization in one neuron is indicated by white arrow. (B) Number of kisspeptin neurons in the ARC of male and female sheep (left graph) and the percent that colocalizes with NK3R (right graph). (C) Number of NKB neurons in the ARC of 
male and female sheep (left graph) and the percent that colocalizes with NK3R. Asterisk indicates a significant difference from males $(\mathrm{p}<0.05)$.

Figure 3.5. NKB and NK3R immunoreactivity in the RCh of acutely-castrated female (A) and male (B) sheep. Photomicrographs of confocal images (1 $\mu \mathrm{m}$ thick optical section) illustrating NKB (green), Nissl staining (purple), and NK3R (red) in the RCh of female (A) or male (B) sheep. White arrowheads represent contacts. Scale bar $=50 \mu \mathrm{m}$. (C) Number of NKB inputs to NK3Rcontaining cells in the RCh. Asterisk indicates a significant difference from males $(\mathrm{p}<0.05)$. 
Figure 3.1.
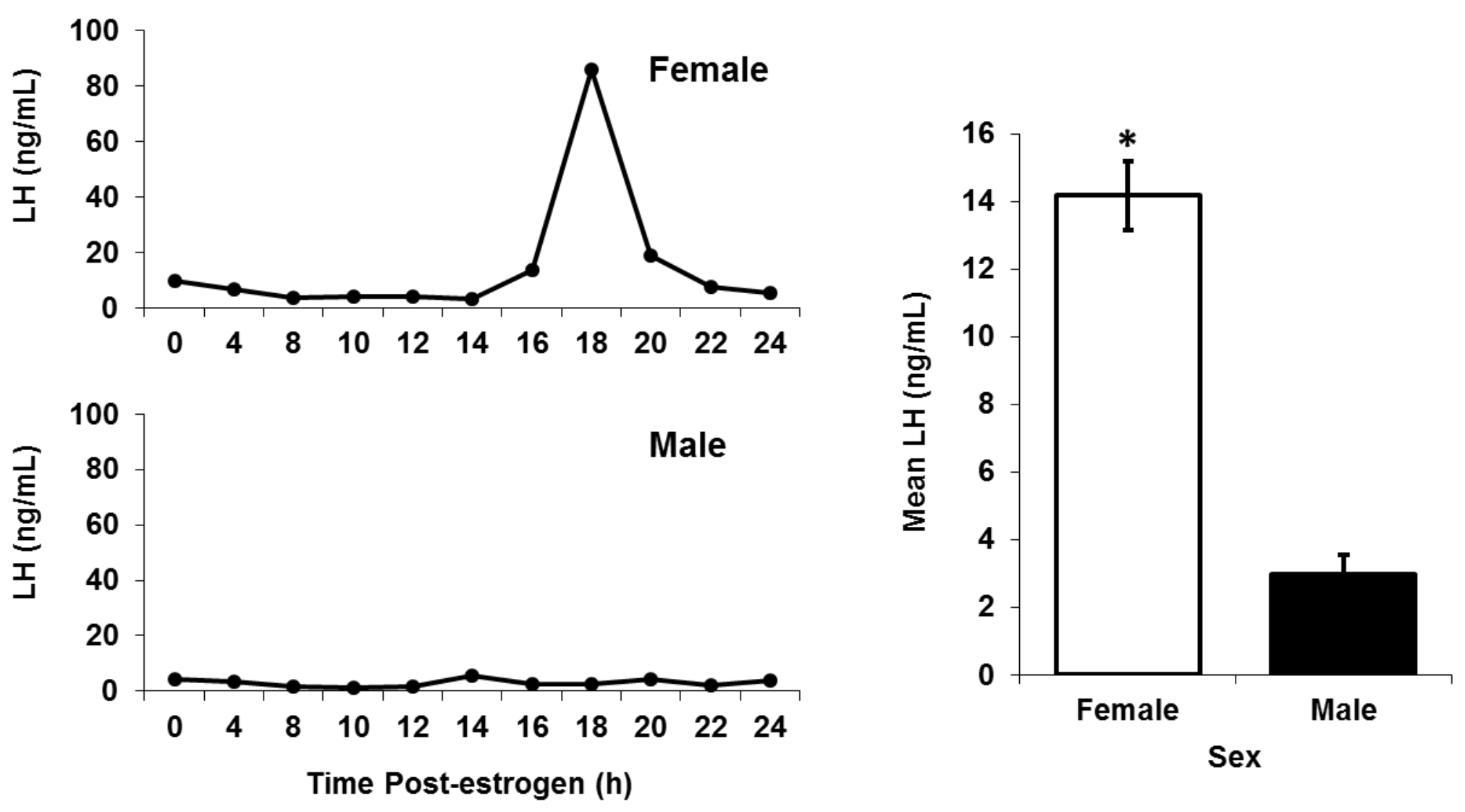
Figure 3.2.

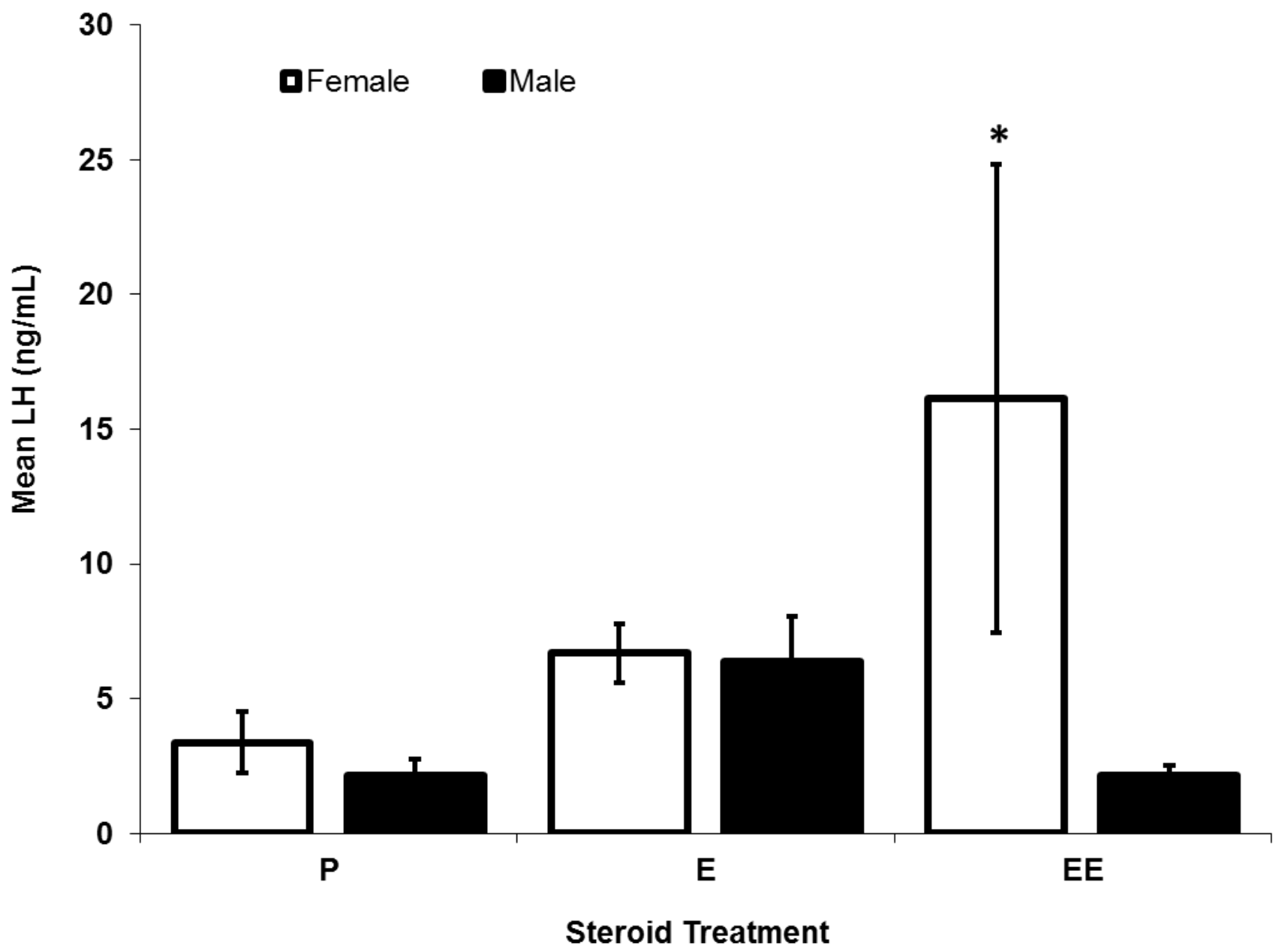


Figure 3.3.
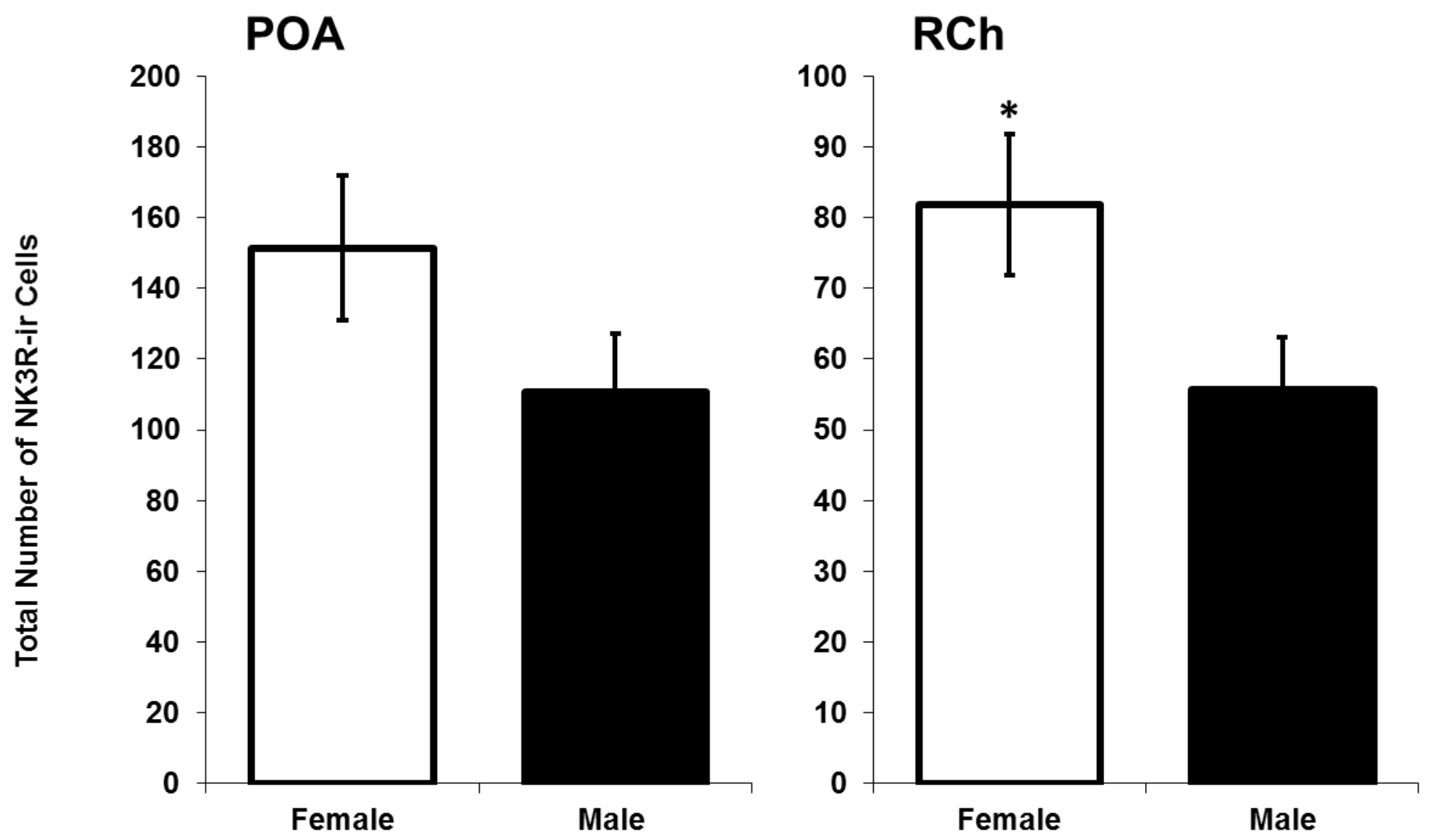

Sex 
Figure 3.4.

A

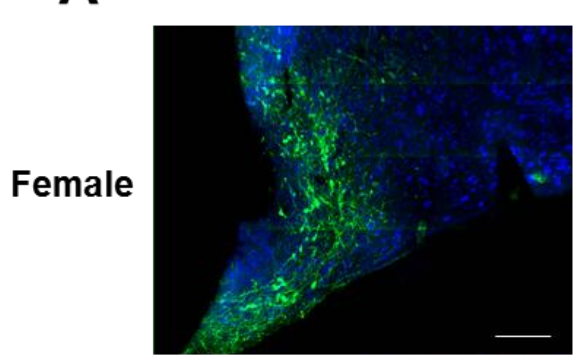

NK3R

Merged
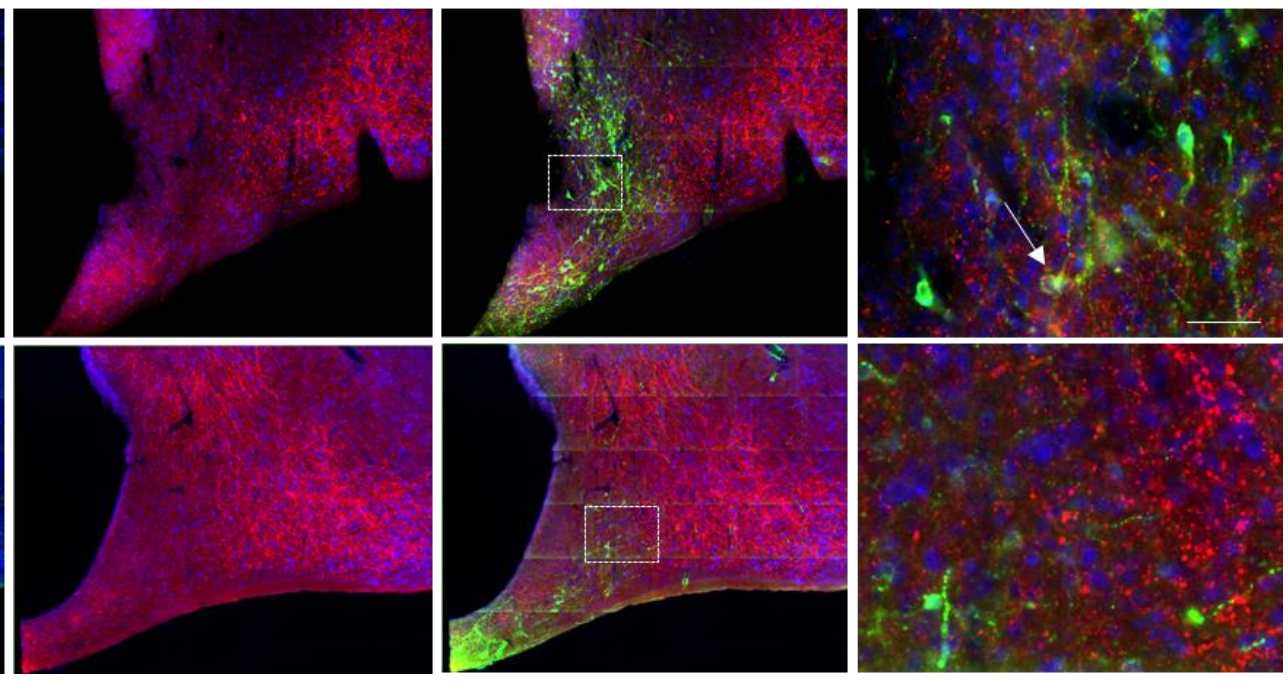

B
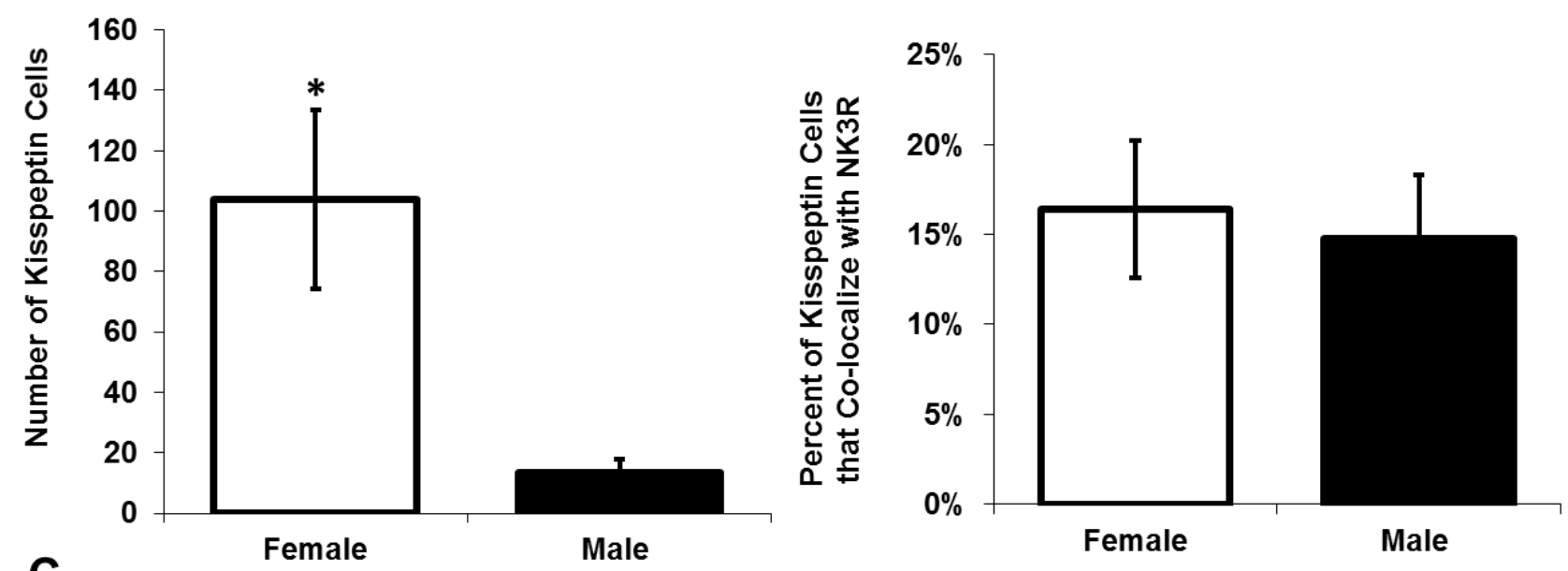

C
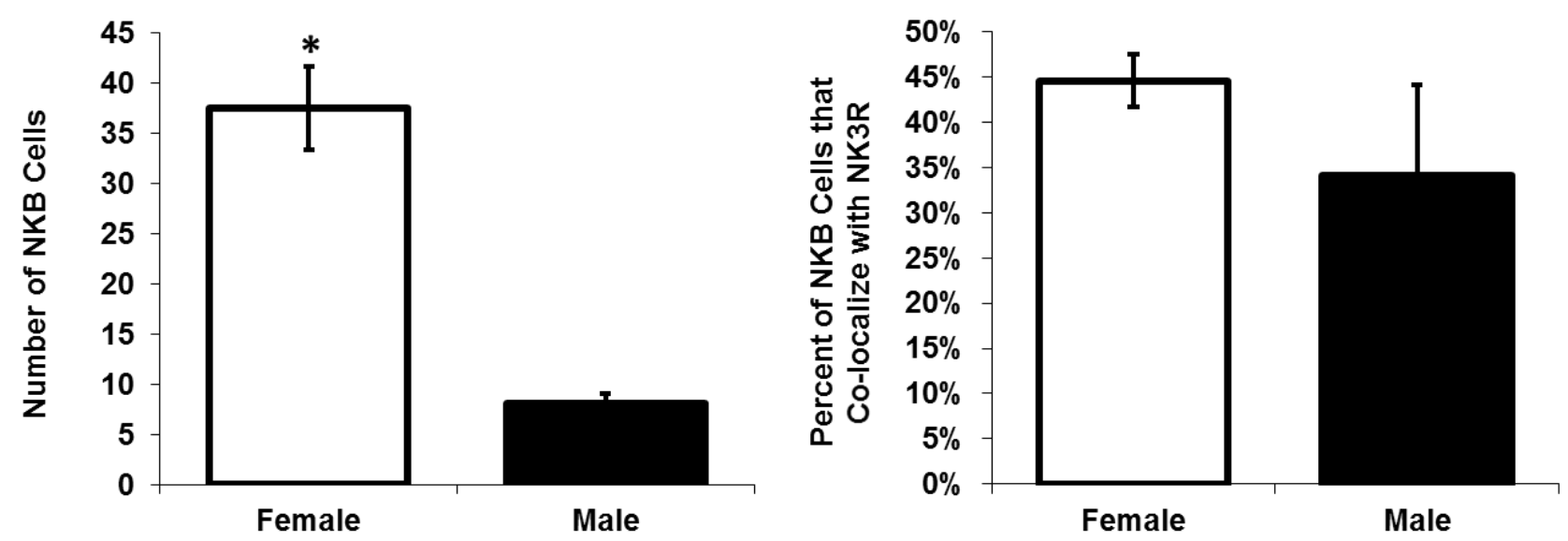
Figure 3.5.
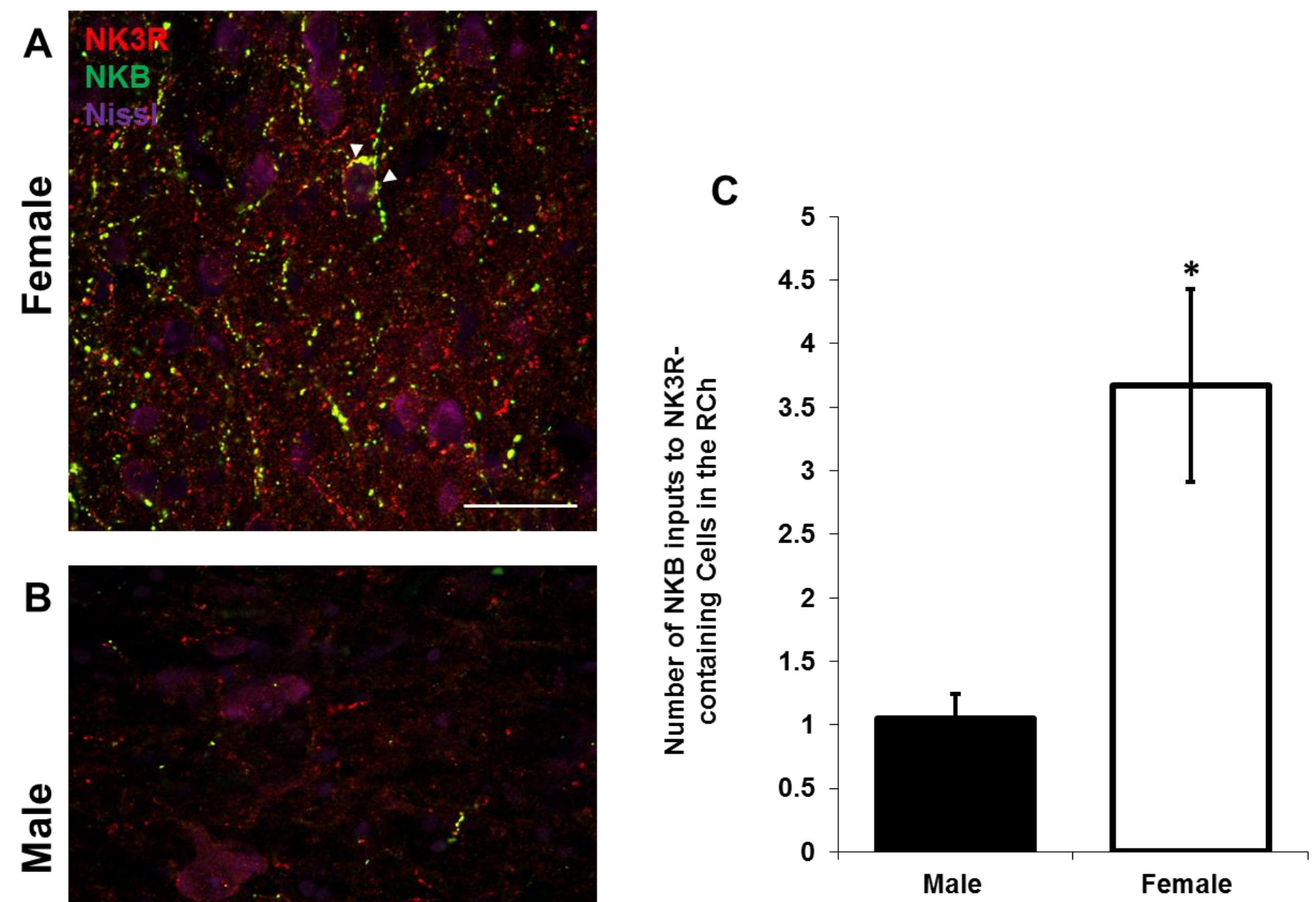
Morphological and Functional Evidence of Sexual Dimorphism in the Retrochiasmatic Area Population of NK3R-containing Neurons in Sheep

\section{CHAPTER IV}

A Possible Role for Galanin Neurons in Mediating the Effects of NKB During the LH Surge 
A Possible Role for Galanin Neurons in Mediating the Effects of NKB During the LH

Surge

Justin A. Lopez, Richard B. McCosh, Michelle N. Bedenbaugh, Ashley N. Lindo, Elizabeth C.

Bowdridge, Stanley M. Hileman, Robert L. Goodman

Department of Physiology and Pharmacology, West Virginia University, Morgantown, WV

\section{Abbreviated Title: Galanin Expression in the Ovine Retrochiasmatic Area}

Key Terms: GnRH, NK3R, kisspeptin, galanin, reproduction, hypothalamus, sheep

Corresponding author and person to whom reprint requests should be addressed:

Robert Goodman, Ph.D.

PO Box 9229

Department of Physiology and Pharmacology

West Virginia University

Morgantown, WV 26505

Phone: 304-293-1496

Email:rgoodman@hsc.wvu.edu

Disclosure statement: The authors have nothing to disclose 


\section{Abstract:}

Neurokinin B (NKB) is critical for fertility in humans and stimulates GnRH/LH secretion in humans, primates, and sheep. We have recently demonstrated that NKB actions via its receptor, $\mathrm{NK} 3 \mathrm{R}$, in the retrochiasmatic area $(\mathrm{RCh})$ contribute to surge-like LH secretion in sheep. The true phenotype of these NK3R-containing neurons, however, has yet to be elucidated. Based on its anatomical location in sheep, one potential candidate is galanin. We thus first determined if this neurotransmitter is found in NK3R-immunoreactive neurons in the RCh and if a sexual dimorphism exists in its expression within the RCh. Using dual-label immunohistochemistry, we observed that galanin co-localized in about $20 \%$ of RCh NK3R neurons for both male and female sheep. Using microinjections of the retrograde tract tracer CT $\beta$ into the arcuate nucleus (ARC), we next demonstrated that some of these galanin neurons project directly to the ARC. Furthermore, we assessed the effects of central galanin administration on pulsatile LH secretion and galantide (galanin receptor antagonist) infusion during an estrogen-induced LH surge. There was a tendency for galanin to stimulate LH pulse frequency during anestrus $(p=0.07)$ and to increase LH pulse amplitude during the breeding season ( 5 nmole dose; $\mathrm{p}=0.06)$. During an estrogen-induced surge, galantide infusion resulted in a minor inhibitory effect on surge amplitude (approximately by 25\%; not statistically significant) without altering the time of the LH peak. These results provide neuroanatomical evidence that galanin could mediate the actions of NKB in the RCh of the ewe, however, more work is needed to rigorously test this hypothesis. 


\section{Introduction:}

The neuroendocrine pathways that control ovulation in females have been the subject of intense investigation over the last fifty years (1-5). High levels of estradiol produced by the maturing follicle(s) act to induce a GnRH surge that in turn elicits a corresponding surge of LH, which then causes ovulation. The molecular and neural mechanisms that mediate the interplay between estrogen and GnRH are still not fully understood. GnRH neurons are devoid of estrogen receptor alpha $(\mathrm{ER} \alpha)(6)$, the receptor subtype whereby estrogen exerts its effects, thus, intermediary neurons must participate in this process.

Galanin, a neuropeptide widely expressed throughout the central and peripheral nervous systems $(7,8)$, has been implicated in the control of GnRH release $(5,9)$. The highest concentrations of galanin have been observed in the $\mathrm{MBH}$ of numerous species, including rats (10), primates (11), pigs (12), and sheep (13). In the POA, galanin is colocalized with a sub-population of GnRH neurons in female rats (approximately $65 \%$ of $\mathrm{GnRH}$ neurons) $(14,15)$ and female primates (approximately $10 \%$ of GnRH neurons) (7). This population of galanin neurons also appears to be highly sensitive to the steroid environment in rats as, during proestrus, significantly higher levels of galanin are found in the POA compared to during estrus (16). Moreover, the incidence of colocalization of GnRH and galanin at the level of single axon terminals in the median eminence was dramatically decreased by ovariectomy, but this was reversed by administration of estradiol (17). Furthermore, galanin receptor subtype 1 (Gal-R1) has been observed in GnRH neurons in the POA of rats (18) and the presence of galanin close-appositions on GnRH neurons has been shown in rats (16), mice (19), and humans (20). 
Galanin is released in pulses into the hypothalamus-pituitary vasculature, with much higher concentrations found in the portal than peripheral circulation in rodents; the majority of these pulses are coincident with pulses of GnRH (21). Steroid milieu appears to be important as galanin administration failed to suppress LH release in OVX rats, but it readily increased plasma LH levels in OVX rats pre-treated with estradiol benzoate (22). Furthermore, central administration of galantide, a non-specific galanin receptor antagonist, not only suppressed the endogenous LH surge, but also blunted a progesterone-induced LH surge in rats (26). Interestingly, mice with a genetic deletion of galanin and/or Type 2 galanin receptor (Gal-R2) remain reproductively competent (23-25). These findings, in conjunction with the observations that a subpopulation of GnRH neurons co-express galanin in the POA and are activated during the LH surge (27), implicates at least a partial involvement of galanin during the LH surge in rodents.

In sheep, the role of galanin in LH secretion is less characterized. Although the amount of colocalization between GnRH and galanin does not appear to be regulated by steroids (nearly all GnRH neurons in the medial POA co-express galanin) (28), galanin expression in other brain regions or regions of the hypothalamus may be influenced by steroid environment. This is supported by the findings that ER $\alpha$ is expressed in galanin neurons (29) and the number of galanin fiber close-appositions to GnRH cell bodies are increased in the presence of surge-inducing levels of estradiol (8). Additionally, the number of galanin-immunoreactive neurons in the caudal part of the POA was increased after administration of estradiol compared to controls. Galanin receptor subtypes 1 - 3 (Gal-R1, Gal-R2, Gal-R3) have also been detected throughout the POA, hypothalamus, and pituitary gland (30), and a subset of GnRH neurons have been shown to express 
Gal-R1 mRNA (similar to what is seen in female rats) (31). Although Gal-R2 has been observed in a large number of neurons throughout the hypothalamus, it has not been shown to colocalize with GnRH in sheep (32).

To date, the involvement of galanin during the LH surge has yet to be examined in sheep. We have previously demonstrated that senktide, a NK3R agonist, acts in the retrochiasmatic area (RCh) of the ovine hypothalamus to elicit a surge-like increase in LH $(33,34)$. Furthermore, pharmacologic blockade of NK3R signaling within the RCh reduced the amplitude of the LH surge by approximately 50\% (34). This finding demonstrates that NK3R activation in the RCh is essential for full expression of the preovulatory LH surge. Additionally, administration of microimplants containing senktide into the RCh led to activation of kisspeptin neurons located in the arcuate nucleus (ARC) (35). Because neurons in the RCh innervate ARC kisspeptin (i.e., KNDy) neurons (35), we hypothesized that direct activation of ARC KNDy neurons by NK3R-containing neurons in the RCh plays an important role in the GnRH and LH surge of ewes. However, the phenotype of these NK3R-containing neurons within the RCh remains to be determined. Based on the anatomical distribution of galanin neurons in the ovine hypothalamus, we hypothesized that NK3R-containing neurons of the RCh also express galanin.

This study was designed to characterize galanin neurons within the $\mathrm{RCh}$ and the involvement of galanin on LH secretion in ewes. Our specific objectives were to 1) determine if RCh galanin neurons contain NK3R in males and females and if RCh galanin neurons project to the ARC in females, 2) assess the effect of central galanin administration on LH secretion during both the 
breeding season and anestrus, and 3) test the effect of galanin receptor blockade on the estrogeninduced LH surge.

\section{Material and Methods:}

\section{Animals:}

For immunohistochemical experiments, Suffolk blackface females and wethers (rams castrated approximately three weeks after birth) born in February or March were used. Experiments for this group were performed during the breeding season (December), when animals were 9 to 10 months of age. For other experiments, multiparous adult ewes of mixed breeding were used. All animals were moved from pasture to a quarantine area where they were fed Timothy Pellets (Standlee Hay Company, Inc., 22349 Kimberly Road, Kimberly, ID) and Triple Crown Complete Pellets (Triple Crown, 315 Lake Street East, Wayzata, MN) for 2 weeks. They were then moved indoors to acclimate to housing within the facility for at least one week before surgeries. Once indoors, sheep were allowed free access to water and mineral blocks and were fed the same diet twice daily to maintain body weight. Animals were maintained in a light- and temperature-controlled facility with the internal lighting environment adjusted to mimic natural changes in day-length.

\section{General Methods:}

\section{Surgeries}


Ovariectomies (OVX) were performed under aseptic conditions. Animals were first anaesthetized by i.v. injection of ketamine $(7 \mathrm{mg} / \mathrm{kg})$ and midazolam $(0.3 \mathrm{mg} / \mathrm{kg})$ and then maintained on $2 \%$ to $5 \%$ isoflurane in oxygen. Ovarian vasculature was ligated, and the ovaries were removed via a mid-ventral incision. Chronic implantation of an 18-gauge needle into the third ventricle and microinjection of the retrograde tract tracer CT $\beta$ into the ARC were performed using a stereotaxic procedure as previously described $(36,37)$. For the former, the cannula was cemented in place with dental acrylic, and the needle hub was plugged and covered with a plastic cap. CT $\beta$ (200 $\mathrm{nl}$ of a $2 \%$ solution) was unilaterally injected into the ARC with a $1 \mu \mathrm{L}$ Hamilton syringe that extended 3 $\mathrm{mm}$ beyond the end of an 18-gauge guide tube. The injection occurred over $3 \mathrm{~min}$ and the needle was left in place for $5 \mathrm{~min}$. The needle and guide tubes were slowly withdrawn, the surface of the brain covered with GelFoam and the skin sutured. Animals were treated pre- and postoperatively with analgesics (carprofen for OVX and neurosurgeries and gabapentin for neurosurgeries) and antibiotics (gentamycin for OVX and neurosurgeries). All pre- and post-operative drugs were acquired from Patterson Veterinary (Bessemer, AL) except gabapentin, which was compounded locally (McCracken Pharmacy, Waynesburg, PA). Animals were allowed to recover from surgery for at least 1 week before experiments were performed.

\section{Steroid replacement and blood sampling procedures}

We used the following well-described (38-41) steroid replacement model in males and females to mimic patterns of ovarian hormones seen during the ovarian cycle: 1) luteal phase levels of estradiol were produced by subcutaneous (sc) insertion a single 1-cm long SILASTIC implant (inner diameter $0.34 \mathrm{~cm}$, outer diameter $0.46 \mathrm{~cm}$; Dow Corning Corp., Midland, MI, USA) 
containing estradiol; 2) follicular phase levels of estradiol were approximated with four, 3-cm long SILASTIC estradiol implants; and 3) luteal phase progesterone patterns were achieved by inserting 2 Controlled Internal Drug Release (CIDR) devices (Zoetis, Parsippany, NJ) sc and leaving these in place for 10-14 days. Previous studies in ewes demonstrated that sc implantation of CIDRs resulted in levels of plasma progesterone that were similar to vaginally inserted CIDRs (40-42). Blood samples (3-4 ml) were collected by venipuncture, placed in heparinized tubes and plasma was stored at $-20^{\circ} \mathrm{C}$ until assayed for $\mathrm{LH}$.

\section{Tissue collection:}

Hypothalamic tissue blocks were collected for immunohistochemical analysis and for histological examination of guide cannula placements as previously described (39). Briefly, animals were treated with heparin $(20,000 \mathrm{U}) 10$ minutes before and at the time of euthanasia, which was accomplished by an intravenous overdose of sodium pentobarbital ( 8 to $12 \mathrm{~mL}$, Euthasol; Patterson Veterinary, Bessemer, AL). Once respiration stopped and there was no eye-blink reflex, the animal was exsanguinated by cutting the carotids, and the head rapidly removed and perfused via the carotid arteries with $4 \mathrm{~L}$ (lambs) or $6 \mathrm{~L}$ (adults) of a solution containing $4 \%$ paraformaldehyde in $0.1 \mathrm{M}$ phosphate buffer $(\mathrm{PB})$ with $0.1 \%$ sodium nitrite. Tissue blocks containing the POA and hypothalamus were removed and stored overnight in fresh paraformaldehyde solution at $4^{\circ} \mathrm{C}$. The following day, blocks were transferred to a solution containing $20 \%$ sucrose in $0.1 \mathrm{M} \mathrm{PB}$ and stored at $4^{\circ} \mathrm{C}$. A microtome with a freezing stage was used to section blocks in $45-\mu \mathrm{m}$ increments. For the studies where galanin was injected or galantide was infused, every fifth section through the MBH was stained with cresyl violet and examined to determine if guide cannulas correctly targeted 
the third ventricle. For the galanin/NK3R co-expression and tract-tracing studies, 10 parallel series of sections ( $450 \mu \mathrm{m}$ apart) were stored in cryoprotectant $(43)$ at $-20^{\circ} \mathrm{C}$.

All procedures were approved by the West Virginia University Animal Care and Use Committee and were performed in accordance with the National Institutes of Health guidelines for the care and use of research animals.

Experiment 1: Determine if galanin expression co-localizes with NK3R within the RCh and if these neurons project to the ARC.

To characterize the expression of galanin and its co-localization with NK3R within the RCh, we used tissue from young wethers $(n=6)$ and acutely OVX female sheep $(n=5)$ that had received two sequential artificial luteal phases that had been collected for other studies (Chapter 2). Tissue was collected during an artificial follicular phase, 18-20 hours after insertion of four long estradiol implants. Blood samples were collected every 12 min for 2 hours immediately prior to tissue collection. To determine if galanin-containing neurons projected to the ARC, tissue was collected from three ovary intact adult ewes 9-10 days after unilateral injection of CT $\beta$ into the ARC.

\section{Immunohistochemistry:}

For detection of NK3R and galanin, dual-label immunohistochemistry was performed on a complete series of free-floating hemi-sections throughout the RCh from each animal. All washes were performed at room temperature under gentle agitation with phosphate-buffered saline (PBS). 
Sections were rinsed 4 times for 5 minutes between incubations unless noted otherwise. On the first day, tissue sections were rinsed thoroughly 12 times at 15 minutes each. After PBS washes, tissue sections were incubated for 1 hour in $1 \% \mathrm{H}_{2} \mathrm{O}_{2}$ for 10 minutes, rinsed, and incubated in $20 \%$ normal goat serum (NGS; Jackson Immunoresearch, West Groove, PA) in PBS containing 0.4\% triton X-100 before overnight incubation with rabbit anti-porcine Galanin (1:500) (Phoenix, Catalog \#H-026-06, Lot 01578-1) (PBST with 4\% NGS). On the second day, sections were rinsed and then incubated in biotinylated goat anti-rabbit immunoglobin (1:500 in 4\% NGS; Vector BA1000, Lot ZA0520) for 1 hour, followed by ABC-elite (1:500 in PBS; Vector Laboratory Burlingame, CA) for 1 hour. Sections were rinsed again and incubated for 10 minutes in biotinylated tyramine (TSA) (dilution 1:250; Perkin Elmer, Waltham, MA, USA) in PBS containing $3 \% \mathrm{H}_{2} \mathrm{O}_{2}$ per $1 \mathrm{~mL}$ of solution. After rinsing, sections were incubated in DyLight green 488-conjugated to streptavidin (1:100 in PBS; Fisher Scientific) for 30 minutes, followed by rinses and incubation for 1 hour in 4\% NGS. Sections were incubated overnight with rabbit anti-NK3R (dilution 1:1,000 in 4\% NGS; Novus, Catalog \#NB300-102, Lot F1). On the third day, sections were rinsed and then incubated in Alexa555 goat anti-rabbit (dilution 1:100 in 4\% NGS; Life Technologies, Carlsbad, CA, USA) for 30 minutes. Sections were rinsed again before being incubated with Neurotrace 640/600 Deep Red Fluorescent Nissl Stain (1:100 in PBS; Life Technologies; Lot N21483) for 20 minutes. Sections were then rinsed in phosphate buffer (PB), mounted on charged Superfrost slides (Fisher Scientific), cover-slipped using Gelvatol and stored in the dark at $4^{\circ} \mathrm{C}$ until analyzed. 
The procedure for dual immunohistochemistry of galanin and CT $\beta$ was identical to that for galanin and NK3R, except that rabbit anti-CT $(1: 1,000)$ (C3062; Sigma-Aldrich) (PBST with 4\% NGS) was used rather than the antibody against NK3R.

\section{Analysis of NK3R and galanin immunoreactivity in the RCh:}

The total number of NK3R-ir and galanin cells in the RCh was assessed using an upright fluorescent microscope (VS120; Olympus, Tokyo, Japan) with a 20x objective. The total number of cells represents the sum of cell numbers in three representative RCh hemi-sections that extended in the lateral direction from the fornix to the medial edge of the optic tract, dorsally from the fornix to the base of the brain and approximately $1.4 \mathrm{~mm}$ (three hemi-sections) posterior to the optic chiasm $(41,44,45)$. Galanin cell numbers and the percentage that colocalized with NK3R were totaled across 3 hemi-sections. All cell counts were made by an observer blinded to treatment groups.

\section{Analysis of CT $\beta$ and galanin immunoreactivity in the RCh:}

To examine CT $\beta$ and galanin immunoreactivity in the $\mathrm{RCh}$, sections processed for dualimmunofluorescence were captured across at least 2 sections per side of the RCh ipsilateral to injection for each animal using a Hamamatsu Orca Flash 4.0 monochrome cMOS camera on a Nikon A1R confocal microscope (Nikon Instruments Inc., Melville, NY) with a Plan Apochromat VC 60X Oil/1.4 WD $(130 \mu \mathrm{m})$ objective. Confocal Z-stacks of optical sections were taken at $1 \mu \mathrm{m}$ 
intervals through image. СT $\beta$ and galanin immunoreactivity was visually analyzed using the Nikon software, NIS Elements.

\section{Experiment 2: Does galanin act in the hypothalamus to regulate tonic LH secretion in intact anestrous ewes?}

Six ovary-intact anestrous ewes received a permanent cannula into the third ventricle in mid-April (anestrous season). Ewes were randomly assigned to receive a single icv injection of galanin (2 nmol in $150 \mu \mathrm{L}$ sterile saline) or vehicle $(150 \mu \mathrm{L}$ sterile saline $)$; this dose was selected as a conservative estimate per previous data in rodents and one report in sheep $(26,46,47)$. Blood samples were collected every 12 min for a total of 6 hours; galanin or saline was injected icv after 2 hours of sampling. The protocol was repeated one week later, at which time each animal received the alternate treatment in a crossover design.

Experiment 3: Does galanin act in the hypothalamus to regulate tonic $\mathrm{LH}$ secretion in luteal phase ewes?

Six ovary-intact ewes received a permanent cannula into the third ventricle in mid-October (breeding season). Estrous cycles were synchronized with 2 intramuscular injections of prostaglandin F2 $\alpha(20 \mathrm{mg})$ (Lutalyse, Zoetis, Parsippany, NJ) given 7 days apart (48). Ten days after the second treatment with prostaglandin (day 8 of cycle, mid-luteal phase), blood samples were collected every $12 \mathrm{~min}$ for $36 \mathrm{~min}$ and a single dose of galanin $(0,2,5,10$ nmoles $)$ was injected icv. Blood collection continued for 8 hours with a second, different dose given 4 hours 
after the first injection. Doses were administered in a random order to control for carry-over effects. Ewes were given prostaglandin the day after sampling and the protocol repeated on day 8 of the next luteal phase, with each ewe receiving the two doses that she did not receive in the first replicate.

\section{Experiment 4: Effect of galantide on the LH surge during the breeding season}

Six breeding season ewes were ovariectomy (OVX) and received a permanent cannula into the third ventricle in mid-October (breeding season). Ewes received a single 1-cm estradiol implant and two CIDRs at time of OVX. Approximately 10-14 days later, CIDRs were removed and the next day four, 3-cm estradiol implants were placed sc to induce a LH surge. The following day, ewes were restrained in their pen and a harness containing a pack for a battery-operated pump strapped to their backs. Ewes were randomly assigned to receive either saline $(60 \mu \mathrm{L} /$ hour $)$ or galantide (15 nmoles/60 $\mu \mathrm{L} /$ hour) infused into the third ventricle for 12 hours, starting 10 hours after insertion of estradiol-containing implants. This dose was chosen because we saw no effect of 5 nmoles/60 $\mu \mathrm{L} /$ hour galantide on the LH surge in a preliminary experiment during anestrus. Infusions lines, pumps, and packs were then removed and animals again allowed free movement in the pen. Blood samples were collected via jugular venipuncture every 4 hours for the first 8 hours and then every 2 hours for the remaining 32 hours. After sampling, the four long estradiol implants were removed and two CIDRs inserted. This protocol was then repeated 10 days later using a cross-over design.

\section{Data Analysis:}




\section{Radioimmunoassay:}

Radioimmunoassays for LH were performed as previously described for ovine samples (49). Briefly, LH concentrations were measured in duplicate using $100-200 \mu \mathrm{L}$ of plasma per sample via a double-antibody radioimmunoassay with reagents supplied by the National Hormone and Peptide Program (Torrance, CA, USA). The sensitivity of the assay averaged $0.06 \mathrm{ng} /$ tube, and the intra- and interassay variability was $13.4 \%$ and $14.1 \%$, respectively.

\section{Statistical analysis:}

For Experiments 2 and 3, mean LH concentration, LH pulse frequency and LH pulse amplitude (maximal pulse value minus preceding nadir) were determined during the 4-hour post-injection sampling periods and analyzed by two-way analysis of variance (ANOVA) with repeated measures (time and treatment as main factors). Pulses were identified using established criteria (50). Briefly, a pulse had to be 2 assay standard deviations greater than the preceding nadir, the pulse had to occur within two samples of the preceding nadir, and the amplitude had to be greater than the assay sensitivity. Post-injection response time (time from injection to the first pulse) was compared between treatment groups with a paired t-test. The proportion of animals responding to galanin treatment within 1 hour was compared using Chi-Square analysis.

For Experiment 4, the time to maximal LH secretion and the amplitude of the LH surge (maximal concentration minus LH concentration of the first sample collected at time of insertion of large 
estradiol implants) were compared between treatment groups with paired t-tests. Data are reported as mean \pm SEM. Differences were considered significant when $\mathrm{P}<0.05$.

\section{Results:}

\section{Experiment 1: Determine if galanin co-localizes with NK3R within the RCh and if these neurons project to the ARC.}

As expected, mean LH concentrations were much higher in females compared to males at the time of tissue collection $(97.9 \pm 38.6 \mathrm{ng} / \mathrm{mL}$ vs $3.82 \pm 0.61 \mathrm{ng} / \mathrm{mL})$ and the number of NK3R-ir cells in the RCh was greater in females than in males (female $114.2 \pm 18.9$ vs male $83.8 \pm 5.7$ cells) Approximately $20 \%$ of these NK3R-ir neurons also contained galanin, although there was no difference between the sexes (female $21.8 \pm 4.9 \%$ vs male $25.1 \pm 3.1 \%$; $\mathrm{P}=0.60$ ); a much larger percentage of galanin neurons contained NK3R, however this was also not sexually dimorphic: female $51.3 \pm 6.7 \%$ vs male $65.4 \pm 5.4 \%(\mathrm{P}=0.07)$. The number of galanin-immunoreactive cells found within the RCh was also not sexually dimorphic: female $44 \pm 7.3$ cells vs male $32 \pm$ 4.2 cells (Fig. 4.1 ).

Confocal analysis of fluorescence-stained sections confirmed that CT $\beta$-immunoreactive neurons co-expressed galanin within the RCh (Fig. 4.2). From a qualitative perspective, neurons expressing CT $\beta$ were readily observed in the RCh on the ipsilateral side of CT $\beta$ injections in the ARC and some of these contained galanin, but this was not analyzed quantitatively. CT $\beta$ immunoreactivity was relatively low in the RCh on the contralateral side of the injection site, although some scattered 
CT $\beta$-immunoreactive neurons were occasionally observed. Galanin immunoreactivity was readily visualized on the contralateral side of the injection site.

\section{Experiment 2: Does galanin act in the hypothalamus to regulate tonic LH secretion in intact anestrous ewes?}

Administration of galanin to anestrous ewes had a tendency to increase LH pulse frequency compared to administration of saline: galanin, $1.7 \pm 0.2 \mathrm{ng} / \mathrm{mL}$ versus saline, $1.0 \pm 0.3 \mathrm{ng} / \mathrm{mL}, \mathrm{P}$ $=0.07$ (Fig. 4.3). Additionally, within 1 hour of galanin administration, at least one pulse was observed in all 6 animals. In comparison, at least one pulse was observed in only 3 animals in the hour following administration of saline $(\mathrm{P}=0.02)$. Administration of galanin to anestrous ewes did not significantly affect LH pulse amplitude (galanin, $5.0 \pm 1.6 \mathrm{ng} / \mathrm{mL}$ versus saline, $2.4 \pm 0.7$ $\mathrm{ng} / \mathrm{mL}, \mathrm{P}=0.19$ ) or mean $\mathrm{LH}$ concentration (galanin, $1.7 \pm 0.6 \mathrm{ng} / \mathrm{mL}$ versus saline, $1.3 \pm 0.1$ $\mathrm{ng} / \mathrm{mL}, \mathrm{P}=0.20$ ) (Fig. 4.3).

\section{Experiment 3: Does galanin act in the hypothalamus to regulate tonic LH secretion in luteal phase ewes?}

Administration of a $5 \mathrm{nmol}$ dose of galanin to luteal phase breeding season ewes had a modest effect on LH pulse amplitude compared to administration of saline: galanin $(5 \mathrm{nmol}), 2.3 \pm 0.6$ $\mathrm{ng} / \mathrm{mL}$ versus saline, $1.3 \pm 0.1 \mathrm{ng} / \mathrm{mL}, \mathrm{P}=0.06$ (Fig. 4.4). No effect of galanin at a dose of 2 or 10 nmol was observed on LH pulse amplitude and no dose affected LH pulse frequency or mean LH concentrations (Fig. 4.4). 


\section{Experiment 4: Effect of galantide on the LH surge during the breeding season}

Estradiol treatment resulted in LH surges during the infusion of saline in 5 out of 6 animals (\# 133 excluded). Administration of galantide did not result in a significant decrease in mean amplitude compared to saline (Fig. 4.5). However, the reduction observed was approximately $25 \%$ and there was a clear decrease in LH surge amplitude in two ewes infused with galantide (\# 131 and \# 132) (Fig 4.5). In addition, there was no significant delay in the time to peak after galantide administration compared to saline.

\section{Discussion}

In the present study, we characterized the expression of galanin in the $\mathrm{RCh}$, assessed the amount of colocalization between galanin and NK3R, and determined whether galanin neurons project to the ARC. Furthermore, we evaluated the effect of central administration of galanin on LH secretion in breeding season and anestrous ewes and galanin receptor blockade during an estrogen-induced LH surge. We demonstrated that galanin immunoreactivity in the RCh separately co-localized with NK3R and CT $\beta$ colocalization. These results provide neuroanatomical support for the hypothesis that galanin activity could potentially mediate the effects of NKB on the LH surge in sheep. Additionally, we found evidence for a minor stimulatory effect of galanin on LH pulse frequency during anestrous and LH pulse amplitude during the breeding season. During an estrogen-induced LH surge, we observed that blockade of galanin receptors by galantide infusion resulted in a minor inhibitory effect on surge amplitude (approximately by 25\%; non-significant). In addition to our neuroanatomical findings, these results raise the possibility that endogenous galanin may 
participate in the induction of the LH surge in sheep. However, further work is needed to more rigorously test this hypothesis before making any definitive statements about the role of galanin in LH secretion in ewes.

In this study, we confirmed that the total number of NK3R-containing cells in the RCh was lower in males than females when tissue was collected in the presence of surge-inducing levels of estradiol. In contrast, no difference was observed in the number of galanin-immunoreactive cells found within the RCh between males and females. These results are similar to previous findings that galanin expression throughout the hypothalamus, as a whole, is not sexually dimorphic in sheep $(8,28)$. This is also in contrast to what is observed in rodents, as galanin expression is found to be highly sexually dimorphic in both mice (51) and rats (16). One report observed a slightly stronger intensity of galanin staining in male compared to female sheep and suggested that this indicates a higher cellular content of galanin peptide (28), though assessing modest differences in staining intensity with immunocytochemistry is technically difficult. In this report, there was no noticeable difference in the intensity of galanin immunoreactivity between sexes (Lopez et al., unreported). To our knowledge, this is the first report to demonstrate galanin and NK3R colocalization in any species and represents a first report of the phenotype of a subpopulation of the NK3R-expressing neurons in the RCh. Only about $22 \%$ of the entire NK3R-containing cell population in this region co-expressed galanin and we did not find an effect of sex on the percentage of co-expression or number of galanin neurons. The phenotype of the remaining NK3R neurons and the degree to which these populations participate in the LH surge remains unknown. 
CT $\beta$ was used to determine if galanin neurons located in the RCh project to the ARC. CT $\beta$ immunoreactive neurons were readily observed via confocal analysis in the RCh on the ipsilateral side of tissue collected from females with unilateral injections of CT $\beta$ in the ARC. This report is consistent with a previous tract-tracing study in which the anterograde tract tracer BDA was injected in the RCh. BDA-labelled axon terminals were observed in the ARC in close proximity to kisspeptin-immunoreactive soma and dendrites (35). In conjunction with our report, these findings provide evidence for a monosynaptic projection from $\mathrm{RCh}$ galanin neurons to ARC kisspeptin neurons and, thus, for a potential neuroanatomical circuit responsible for inducing a preovulatory LH surge in ewes $(35,52)$.

Despite the neuroanatomical evidence implicating galanin stimulation of LH release, central administration of galanin to anestrous or breeding season ewes only had modest effects on LH pulse frequency and amplitude, respectively. Although it was observed that all anestrous animals responded within 1 hour of administration of galanin, sustained LH release was not observed in either anestrus or during the breeding season. A couple of methodological considerations could account for the lack of sustained effects observed in this study: 1) method of delivery and 2) dose of galanin used. Because galanin was administered into the third ventricle, a specific site or sites of action cannot be ascertained. Given that galanin receptors are expressed throughout the POA and hypothalamus and affect numerous other neuroendocrine functions $(28,47,53,54)$, more localized administration of galanin is likely necessary to potently effect sustained LH release. Furthermore, using a higher dose of galanin could have been more effective. The doses used in the studies herein are conservative and based on a previously-reported dose used to assess the effect of galanin administration on growth hormone concentrations (47). The doses used in our studies 
may not be sufficient to produce consistent results. As such, injection of a higher dose of galanin in a more localized region may provide clearer insight regarding the involvement of galanin in ovine LH secretion.

Although several lines of correlative evidence in sheep (as presented above and elsewhere) and pharmacological data in rodents (26) support a role for galanin in surge-type LH secretion, galanin receptor blockade with galantide administration did not significantly alter LH surge secretion in our experiments. As stated above, several methodological or theoretical considerations could account for the lack of effect of these drugs. A more effective concentration of galantide and more localized administration may be necessary to markedly affect surge secretion of LH. Notably, the maximum effect we have observed with disruptions of NKB-NK3R signaling in the RCh is a 50\% decrease in amplitude of the surge (Goodman et al., 2018, International Congress of Neuroendocrinology Abstract) (34), so it might not be too surprising that we only reduced surge amplitude by $25 \%$. This would also be consistent with the fact that only $~ 20 \%$ of NK3R neurons in the RCh are galanin positive. Thus, the contribution of galanin to the surge may not be as robust as the entirety of the NK3R-containing population of neurons within the RCh. Additionally, several redundant systems contribute to the generation of the LH surge (5). Because of this, compensatory pathways could mask any effects caused by blocking the actions of galanin. During an estrogen-induced surge, galantide infusion collectively resulted in a relatively minor inhibitory effect on surge amplitude (approximately by 25\%) and did not influence timing of the surge. However, in 2 of the 5 animals wherein galantide administration coincided with surge release, amplitude was reduced by approximately 50\%. A similar degree of reduction in the amplitude of the LH surge has been shown after icv administration of both a Kiss1r antagonist (55) and NK3R 
antagonist (34). These findings raise the possibility that galanin may be acting on the same populations of neurons that are affected in these previous studies. Additionally, neither the NK3R nor Kiss1r antagonist altered the timing of the surge. As such, the lack of an effect of galantide on this variable was not surprising $(34,55)$.

In summary, we demonstrated that galanin/NK3R colocalization in the RCh exists to the same degree in both males and females. We further showed that galanin and CT $\beta$ colocalize in the RCh following injection of CT $\beta$ in the ARC. Thus, NKB may stimulate NK3R-containing galanin neurons in the RCh that project to the ARC to stimulate kisspeptin release from KNDy neurons and, in this way, is important for normal LH surge generation. At this time, there is limited pharmacological data supporting this hypothesis, because only modest effects were observed with galanin on tonic LH secretion and galanin receptor blockade on LH surge generation. Thus, further studies are needed to more completely test the possible role of RCh NK3R and galanin-containing neurons in tonic and surge secretion of LH.

\section{Acknowledgements}

We thank Miroslav Valent, Gail Sager, and John Connors for technical assistance with radioimmunoassay and animal surgeries. We also thank Drs. Margaret Minch and Jennifer Fridley for veterinary care, Heather Bungard for care of the sheep, and Dr. Al Parlow and the National Hormone and Peptide program for reagents used to measure LH. We also thank Dr. Amanda Ammer for assistance in image analysis and processing. 
Image capture and image analysis were performed in the West Virginia University (WVU) Microscope Imaging Facility, which has been supported by the WVU Cancer Institute and NIH Grants P20 RR016440, U54 GM104942, and P20 GM103434.

This work was supported by National Institutes of Health (NIH) Grants R01-HD039916, R01HD082135, and P20GM103434 to the West Virginia IDeA Network for Biomedical Research Excellence.

Disclosure Summary: The authors have nothing to disclose. 


\section{References:}

1. Levine JE. New concepts of the neuroendocrine regulation of gonadotropin surges in rats. Biol. Reprod. 1997;56(2):293-302.

2. Khan AR, Kauffman AS. The role of kisspeptin and RFamide-related peptide-3 neurones in the circadian-timed preovulatory luteinising hormone surge. J. Neuroendocrinol. 2012;24(1):131-143.

3. Plant TM. A comparison of the neuroendocrine mechanisms underlying the initiation of the preovulatory LH surge in the human, Old World monkey and rodent. Front. Neuroendocrinol. 2012;33(2):160-168.

4. Clarke IJ. The preovulatory LH surge. A case of a neuroendocrine switch. Trends Endocrinol. Metab. 1995;6(7):241-247.

5. Goodman RL. Neuroendocrine Control of Gonadotropin Secretion: Comparative Aspects. In: Knobil and Neill's Physiology of Reproduction.; 2015:1537-1574.

6. Lehman MN, Ebling FJP, Moenter SM, Karsch FJ. Distribution of estrogen receptorimmunoreactive cells in the sheep brain. Endocrinology 1993;133(2):876-886.

7. Finn PD, Pau KYF, Spies HG, Cunningham MJ, Clifton DK, Steiner RA. Galanin's functional significance in the regulation of the neuroendocrine reproductive axis of the monkey. Neuroendocrinology 2000. doi:10.1159/000054516.

8. Tillet Y, Tourlet S, Picard S, Sizaret PY, Caraty A. Morphofunctional interactions between galanin and GnRH-containing neurones in the diencephalon of the ewe. The effect of oestradiol. J. Chem. Neuroanat. 2012;43(1):14-19.

9. Sillard R, Langel Ü, Jörnvall H. Isolation and characterization of galanin from sheep brain. Peptides 1991. doi:10.1016/0196-9781(91)90146-G.

10. Skofitsch G, Jacobowitz DM. Immunohistochemical mapping of galanin-like neurons in the rat central nervous system. Peptides 1985. doi:10.1016/0196-9781(85)90118-4.

11. Kordower JH, Le HK, Mufson EJ. Galanin immunoreactivity in the primate central nervous system. J. Comp. Neurol. 1992. doi:10.1002/cne.903190403.

12. Pearson PL, Anderson LL, Jacobson CD. The prepubertal ontogeny of luteinizing hormone releasing hormone-like immunoreactivity in the diencephalon and telencephalon of the male Meishan pig brain. Dev. Brain Res. 1996. doi:10.1016/0165-3806(96)00083-1.

13. Chaillou E, Tramu G, Tillet Y. Distribution of galanin immunoreactivity in the sheep diencephalon. J. Chem. Neuroanat. 1999. doi:10.1016/S0891-0618(99)00032-0.

14. Coen CW, Montagnese C, Opacka- Juffry J. Coexistence of GonadotrophinReleasing Hormone and Galanin: Immunohisto- chemical and Functional Studies. $J$. Neuroendocrinol. 1990. doi:10.1111/j.1365-2826.1990.tb00839.x.

15. Merchenthaler I, Lopez FJ, Negro-Vilar A. Colocalization of galanin and luteinizing hormone-releasing hormone in a subset of preoptic hypothalamic neurons: anatomical and functional correlates. Proc. Natl. Acad. Sci. 1990. doi:10.1073/pnas.87.16.6326.

16. Merchenthaler I, López FJ, Lennard DE, Negro-Vilar A. Sexual differences in the distribution of neurons coexpressing galanin and luteinizing hormone-releasing hormone in the rat brain. Endocrinology 1991. doi:10.1210/endo-129-4-1977.

17. Rajendren G. Increased galanin synapses onto activated gonadotropin-releasing hormone neuronal cell bodies in normal female mice and in functional preoptic area grafts in hypogonadal mice. J. Neuroendocrinol. 2002. doi:10.1046/j.1365-2826.2002.00796.x.

18. Mitchell V, Bouret S, Prévot V, Jennes L, Beauvillain JC. Evidence for expression of 
galanin receptor Gal-R1 mRNA in certain gonadotropin releasing hormone neurones of the rostral preoptic area. J. Neuroendocrinol. 1999. doi:10.1046/j.1365-

2826.1999.00399.x.

19. Rajendren G, Li X. Galanin synaptic input to gonadotropin-releasing hormone perikarya in juvenile and adult female mice: implications for sexual maturity. Brain Res. Dev. Brain Res. 2001.

20. Dudás B, Merchenthaler I. Bi-directional associations between galanin and luteinizing hormone-releasing hormone neuronal systems in the human diencephalon. Neuroscience 2004. doi:10.1016/j.neuroscience.2004.05.018.

21. López FJ, Merchenthaler I, Ching M, Wisniewski MG, Negro-Vilar A. Galanin: a hypothalamic-hypophysiotropic hormone modulating reproductive functions. Proc. Natl. Acad. Sci. U. S. A. 1991. doi:10.1073/pnas.88.10.4508.

22. Sahu A, Crowley WR, Tatemoto K, Balasubramaniam A, Kalra SP. Effects of neuropeptide Y, NPY analog (norleucine4-NPY), galanin and neuropeptide K on LH release in ovariectomized (ovx) and ovx estrogen, progesterone-treated rats. Peptides 1987. doi:10.1016/0196-9781(87)90081-7.

23. Gottsch ML, Zeng HK, Hohmann JG, Weinshenker D, Clifton DK, Steiner RA. Phenotypic analysis of mice deficient in the type 2 galanin receptor (GALR2). Mol. Cell. Biol. 2005. doi:25/11/4804 [pii] r10.1128/MCB.25.11.4804-4811.2005.

24. Hohmann JG, Teklemichael DN, Weinshenker D, Wynick D, Clifton DK, Steiner RA. Obesity and endocrine dysfunction in mice with deletions of both neuropeptide $\mathrm{Y}$ and galanin. Mol. Cell. Biol. 2004. doi:10.1016/j.fct.2013.05.039.

25. Wynick D, Small CJ, Bacon A, Holmes FE, Norman M, Ormandy CJ, Kilic E, Kerr NCH, Ghatei M, Talamantes F, Bloom SR, Pachnis V. Galanin regulates prolactin release and lactotroph proliferation. Proc. Natl. Acad. Sci. 1998.

doi:10.1073/pnas.95.21.12671.

26. Sahu A, Xu B, Kalra SP. Role of galanin in stimulation of pituitary luteinizing hormone secretion as revealed by a specific receptor antagonist, galantide. Endocrinology 1994. doi:10.1210/endo.134.2.7507825.

27. Hrabovszky E, Vrontakis ME, Petersen SL. Triple-labeling method combining immunocytochemistry and in situ hybridization histochemistry: Demonstration of overlap between Fos- immunoreactive and galanin mRNA-expressing subpopulations of luteinizing hormone-releasing hormone neurons in female rats. J. Histochem. Cytochem. 1995. doi:10.1177/43.4.7534782.

28. Dufourny L, Schofield N, Skinner DC. Immunoreactive galanin expression in ovine gonadotropin-releasing hormone neurones: No effects of gender or reproductive status. $J$. Neuroendocrinol. 2003;15(11):1062-1069.

29. Tourlet S, Ziyazetdinova G, Caraty A, Tramu G, Delsol G, Tillet Y. Oestradiol effect on galanin-immunoreactive neurones in the diencephalon of the ewe. J. Neuroendocrinol. 2005;17(3):145-151.

30. Whitelaw CM, Robinson JE, Hastie PM, Padmanabhan V, Evans NP. Effects of cycle stage on regionalised galanin, galanin receptors 1-3, GNRH and GNRH receptor mrna expression in the ovine hypothalamus. J. Endocrinol. 2012;212(3):353-361.

31. Dufourny L, Skinner DC. Distribution of galanin receptor 1-immunoreactive neurons in the ovine hypothalamus: Colocalization with GnRH. Brain Res. 2005;1054(1):73-81.

32. Chambers G, Whitelaw CM, Robinson JE, Evans NP. Distribution of galanin receptor- 
2 immunoreactive neurones in the ovine hypothalamus: No evidence for involvement in the control of gonadotrophin-releasing hormone secretion. J. Neuroendocrinol. 2007. doi:10.1111/j.1365-2826.2007.01609.x.

33. Billings HJ, Connors JM, Altman SN, Hileman SM, Holaskova I, Lehman MN, McManus CJ, Nestor CC, Jacobs BH, Goodman RL. Neurokinin B acts via the neurokinin-3 receptor in the retrochiasmatic area to stimulate luteinizing hormone secretion in sheep. Endocrinology 2010;151(8):3836-3846.

34. Porter KL, Hileman SM, Hardy SL, Nestor CC, Lehman MN, Goodman RL. Neurokinin-3 Receptor Activation in the Retrochiasmatic Area is Essential for the Full Preovulatory LH Surge in Ewes. J. Neuroendocrinol. 2014. doi:10.1111/jne.12180.

35. Grachev P, Porter KL, Coolen LM, McCosh RB, Connors JM, Hileman SM, Lehman MN, Goodman RL. Surge-Like Luteinising Hormone Secretion Induced by Retrochiasmatic Area NK3R Activation is Mediated Primarily by Arcuate Kisspeptin Neurones in the Ewe. J. Neuroendocrinol. 2016;28(6). doi:10.1111/jne.12393.

36. Foradori CD, Goodman RL, Adams VL, Valent M, Lehman MN. Progesterone increases dynorphin A concentrations in cerebrospinal fluid, and preprodynorphin messenger ribonucleic acid levels in a subset of dynorphin neurons in the sheep. Endocrinology 2005;146(4):1835-1842.

37. Hileman SM, McManus CJ, Goodman RL, Jansen HT. Neurons of the lateral preoptic area/rostral anterior hypothalamic area are required for photoperiodic inhibition of estrous cyclicity in sheep. Biol. Reprod. 2011. doi:10.1095/biolreprod.111.092031.

38. Skinner DC, Harris TG, Evans NP. Duration and amplitude of the luteal phase progesterone increment times the estradiol-induced luteinizing hormone surge in ewes. Biol. Reprod. 2000;63(4):1135-42.

39. McCosh RB, Szeligo BM, Bedenbaugh MN, Lopez JA, Hardy SL, Hileman SM, Lehman MN, Goodman RL. Evidence that endogenous somatostatin inhibits episodic, but not surge, secretion of LH in female sheep. Endocrinology 2017;158(6):1827-1837.

40. Jackson LM, Mytinger A, Roberts EK, Lee TM, Foster DL, Padmanabhan V, Jansen HT. Developmental programming: Postnatal steroids complete prenatal steroid actions to differentially organize the GnRH surge mechanism and reproductive behavior in female sheep. Endocrinology 2013;154(4):1612-1623.

41. Ahn T, Fergani C, Coolen LM, Padmanabhan V, Lehman MN. Prenatal Testosterone Excess Decreases Neurokinin 3 Receptor Immunoreactivity within the Arcuate Nucleus KNDy Cell Population. J. Neuroendocrinol. 2015;27(2):100-110.

42. Robinson JE, Forsdike RA, Taylor JA. In utero exposure of female lambs to testosterone reduces the sensitivity of the gonadotropin-releasing hormone neuronal network to inhibition by progesterone. Endocrinology 1999;140(12):5797-5805.

43. Watson RE, Wiegand SJ, Clough RW, Hoffman GE. Use of cryoprotectant to maintain long-term peptide immunoreactivity and tissue morphology. Peptides 1986;7(1):155-159.

44. Amstalden M, Coolen LM, Hemmerle AM, Billings HJ, Connors JM, Goodman RL, Lehman MN. Neurokinin 3 receptor immunoreactivity in the septal region, preoptic area and hypothalamus of the female sheep: Colocalisation in neurokinin B cells of the arcuate nucleus but not in gonadotrophin-releasing hormone neurones. J. Neuroendocrinol. 2010;22(1):1-12.

45. Anderson GM, Connors JM, Hardy SL, Valent M, Goodman RL. Oestradiol microimplants in the ventromedial preoptic area inhibit secretion of luteinizing hormone 
via dopamine neurones in anoestrous ewes. J. Neuroendocrinol. 2001;13(12):1051-1058.

46. Pandit MA, Saxena RN. Galanin regulation of lh release in male rats. Indian J. Exp. Biol. 2010. doi:10.1097/01.ASW.0000433001.92396.b5.

47. Spencer GSG, Berry CJ, Bass JJ. Neuroendocrine regulation of growth hormone secretion in sheep. VII. Effects of GABA. Regul. Pept. 1994. doi:10.1016/01670115(94)90052-3.

48. Deaver DR, Stilley NJ, Dailey RA, Inskeep EK, Lewis PE. Concentrations of ovarian and pituitary hormones following prostaglandin F2 alpha-induced luteal regression in ewes varies with day of the estrous cycle at treatment. J. Anim. Sci. 1986.

doi:10.2527/jas1986.622422x.

49. Goodman RL, Coolen LM, Anderson GM, Hardy SL, Valent M, Connors JM, Fitzgerald ME, Lehman MN. Evidence that dynorphin plays a major role in mediating progesterone negative feedback on gonadotropin-releasing hormone neurons in sheep. Endocrinology 2004;145(6):2959-2967.

50. Goodman RL, Karsch FJ. Pulsatile secretion of luteinizing hormone: Differential suppression by ovarian steroids. Endocrinology 1980;107(5):1286-1290.

51. Rajendren G, Gibson MJ. Expression of galanin immunoreactivity in gonadotropinreleasing hormone neurons in mice: A confocal microscopic study. Brain Res. 1999. doi:10.1111/j.1525-1594.2011.01363.x.

52. Merkley CM, Porter KL, Coolen LM, Hileman SM, Billings HJ, Drews S, Goodman RL, Lehman MN. KNDy (kisspeptin/neurokinin B/dynorphin) neurons are activated during both pulsatile and surge secretion of LH in the ewe. Endocrinology 2012;153(11):5406-5414.

53. MELANDER T, FUXE K, HÄRFSTRAND A, ENEROTH P, HÖKFELT T. Effects of intraventricular injections of galanin on neuroendocrine functions in the male rat. Possible involvement of hypothalamic catecholamine neuronal systems. Acta Physiol. Scand. 1987. doi:10.1111/j.1748-1716.1987.tb08201.x.

54. Arvat E, Gianotti L, Ramunni J, Grottoli S, Brossa PC, Bertagna A, Camanni F, Ghigo E. Effect of galanin on basal and stimulated secretion of prolactin, gonadotropins, thyrotropin, adrenocorticotropin and cortisol in humans. Eur. J. Endocrinol. 1995. doi:10.1530/eje.0.1330300.

55. Smith JT, Li Q, Yap KS, Shahab M, Roseweir AK, Millar RP, Clarke IJ. Kisspeptin is essential for the full preovulatory LH surge and stimulates GnRH release from the isolated ovine median eminence. Endocrinology 2011;152(3):1001-1012. 


\section{Figure Legends}

Figure 4.1. Galanin and NK3R immunoreactivity in the RCh of female and male sheep. Top and bottom panels present low- and high-magnification images illustrating galanin (red immunoreactivity), NK3R (green) immunoreactivity, and Nissl staining (blue) in the RCh of a female and male sheep, respectively. Higher magnification images of areas identified by the dashed, white boxes are presented in inset images. Scale bars: standard image $=100 \mu \mathrm{m}$; inset image $=50 \mu \mathrm{m}$. Arrows indicate some galanin (yellow), NK3R (white), and colocalized (red) cells.

Figure 4.2. Galanin- and CT $\beta$-immunoreactivity in the RCh of female sheep. Representative images illustrating galanin (green) and $\mathrm{CT} \beta$ (red) in the RCh ipsilateral and contralateral to injections of CT $\beta$ into one hemisphere of the ARC. Red arrows represent CT $\beta$ neurons, green arrows represent galanin neurons, and yellow arrows represent colocalization between CT $\beta$ and galanin. Scale bar $=50 \mu \mathrm{m}$.

Figure 4.3. Effect of icv injection of galanin $(2 \mathrm{nmol})$ or saline on LH secretion in ovary-intact anestrous ewes $(n=6)$. (A) LH concentration patterns in all animals for the entire 6-hour sampling period (open circle, saline; closed circles, galanin). Pulses are denoted by red (galanin) or blue (saline) circles. (B) Mean LH concentrations ( \pm SEM) post-injection of saline (white bars) or galanin (black bars). (C) Mean Pulse Frequency ( \pm SEM) represents the number of pulses for the 4-hour sampling period post-injection of saline (white bars) or galanin (black bars). (D) Mean Pulse Amplitude ( \pm SEM) for the 4-hour sampling period post-injection of saline (white bars) or galanin (black bars). 
Figure 4.4. Effect of icv injection of galanin or saline on LH secretion in ovary-intact breeding season ewes $(\mathrm{n}=6)$ synchronized with prostaglandin. (A) LH concentration patterns in 2 representative animals for the entire 8-hour sampling period (green line, Day 1; blue line, Day 2). Doses are listed in the order in which they were received and the color that corresponds to the day of treatment (e.g., green, $2 \rightarrow 5=2 \mathrm{~nm}$ dose ( 4 hours) followed by a $5 \mathrm{~nm}$ dose ( 4 hours) on Day 1). Pulses are denoted by open circles. (B) Mean LH concentrations ( \pm SEM) pre-injection (white) or post-injection of galanin at 0 (saline), 2, 5, or $10 \mathrm{~nm}$ doses (corresponding gray and black bars). (C) Mean Pulse Frequency ( \pm SEM) represents the number of pulses for the 4-hour sampling period post-injection of galanin at 0 (saline), 2, 5, or $10 \mathrm{~nm}$ doses (corresponding gray and black bars). (D) Mean Pulse Amplitude ( \pm SEM) for the 4-hour sampling period post-injection of galanin at 0 (saline), 2, 5 , or $10 \mathrm{~nm}$ doses (corresponding gray and black bars).

Figure 4.5. Effect of galantide (red) and saline (black) on the estrogen-induced LH surge during the breeding season. LH concentrations during estradiol-induced LH surges in all animals. Black bar is representative of the infusion period. Right panel: LH surge amplitude (galantide, black bars; saline, white bars), time (hours after estradiol implants) of maximum LH value (galantide, black bars; saline, white bars). 
Figure 4.1.
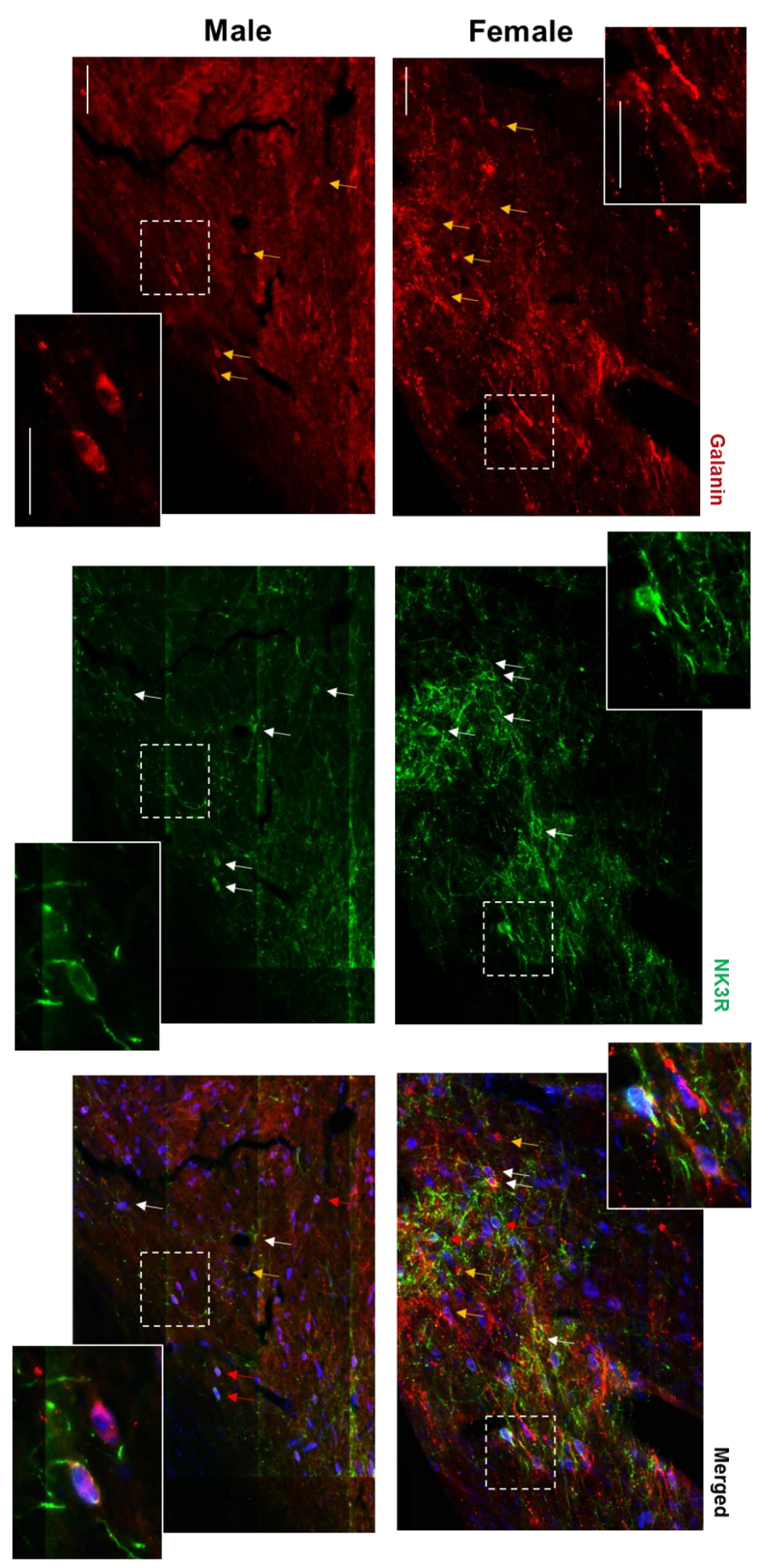
Figure 4.2
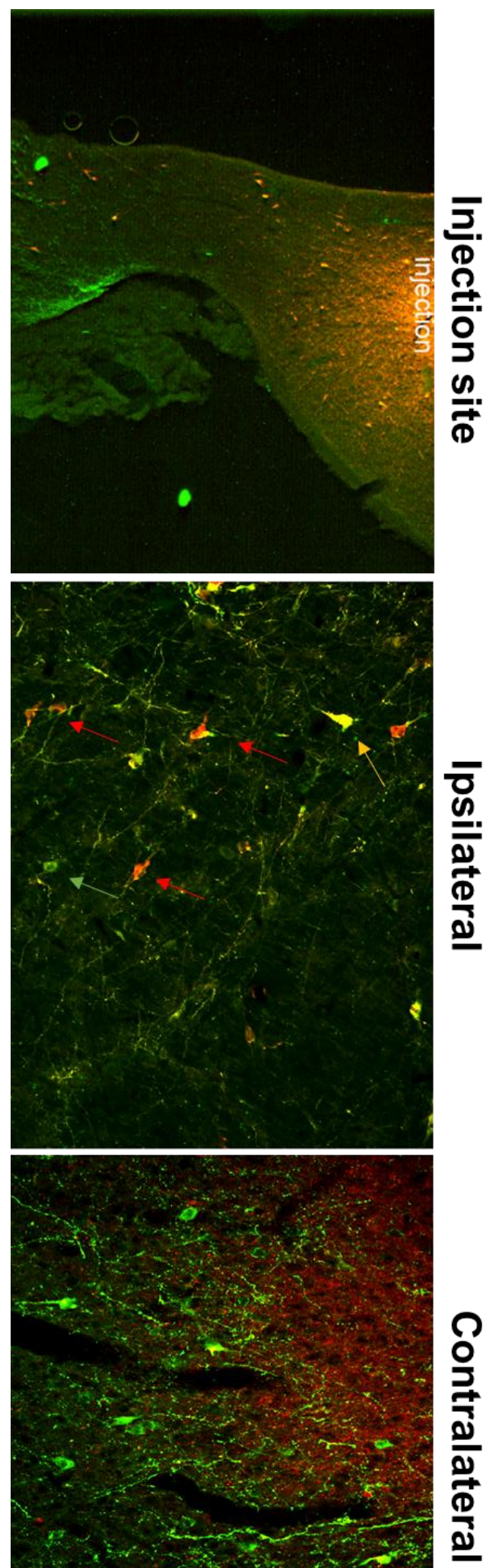
Figure 4.3.
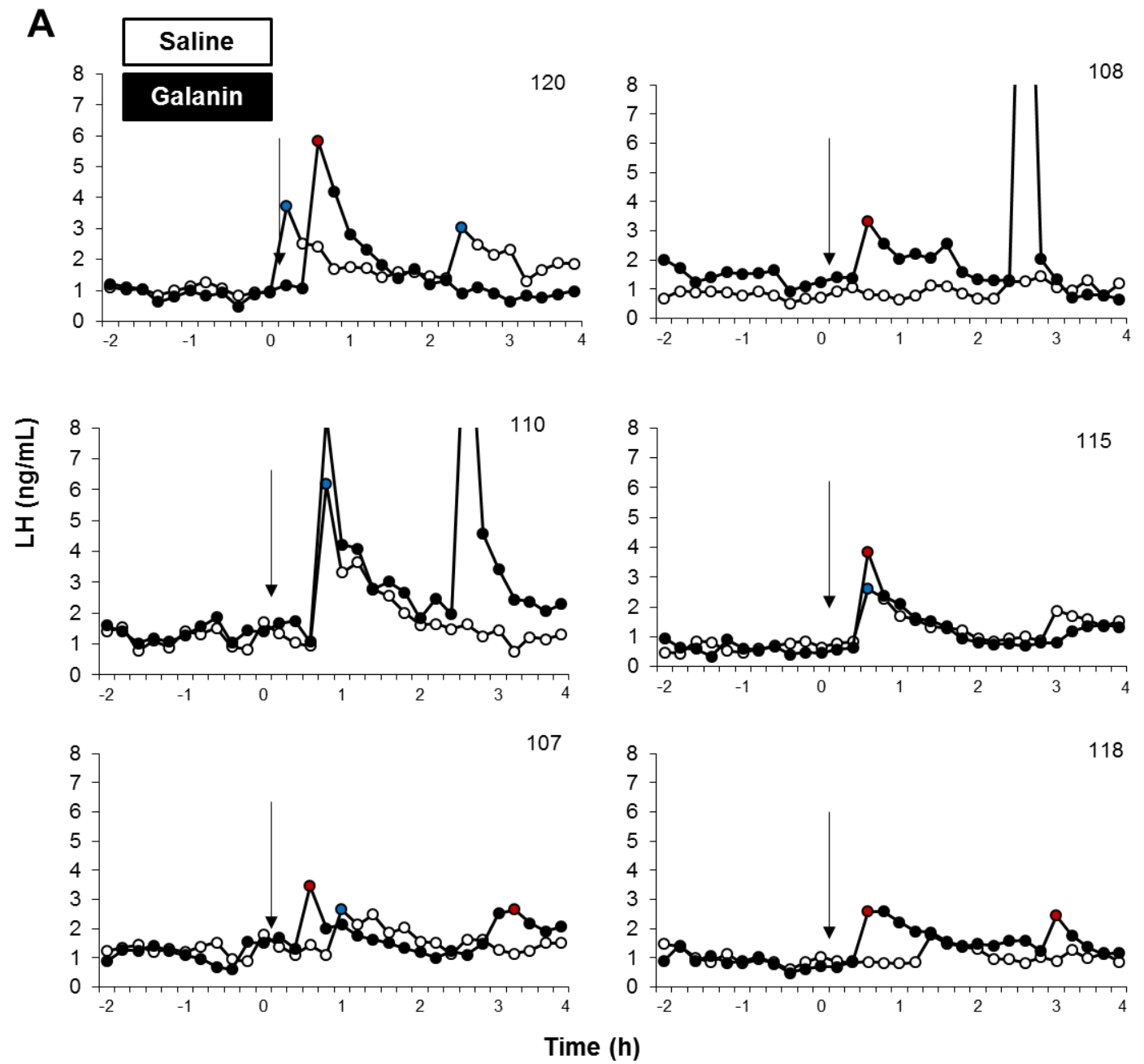

B

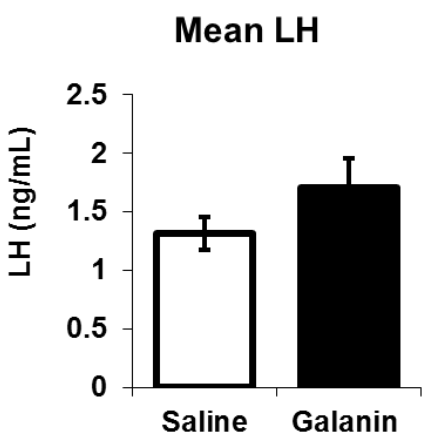

C Pulse Frequency

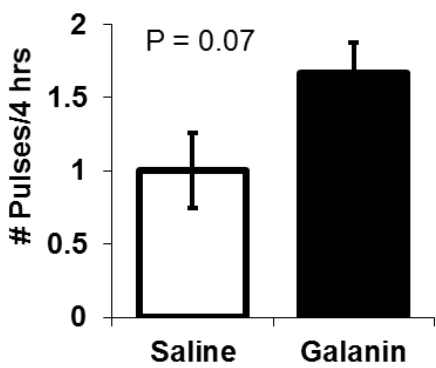

D

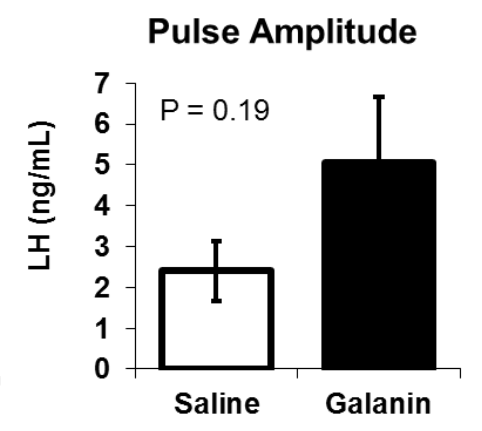


Figure 4.4.
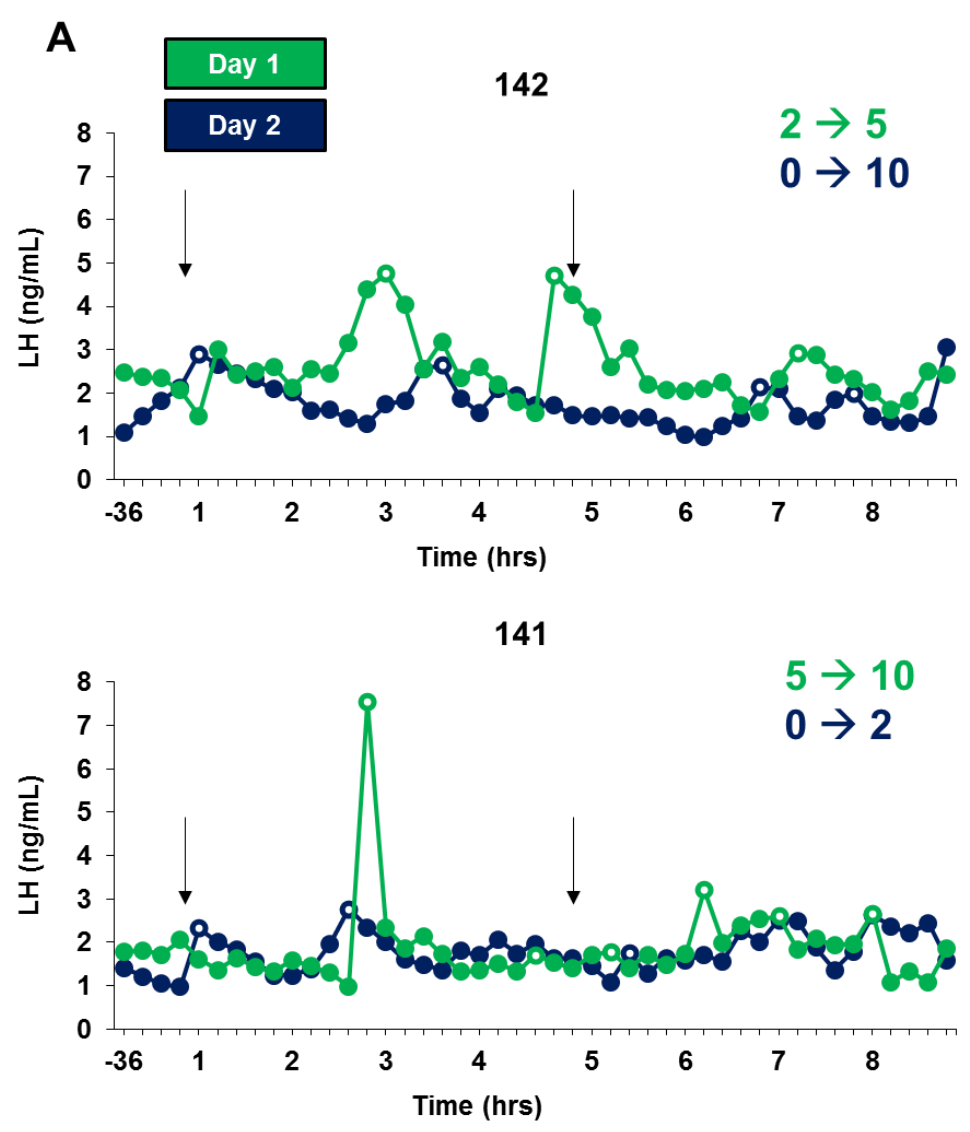

B
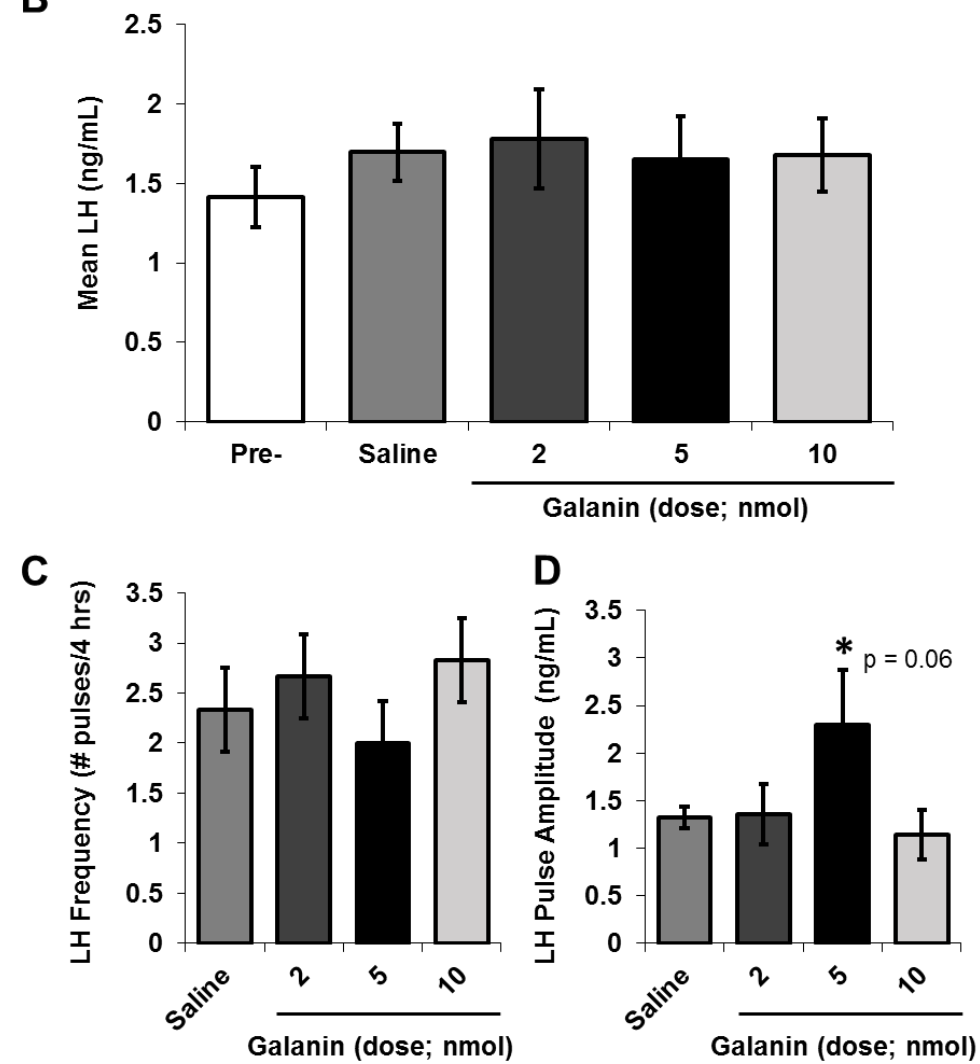
Figure 4.5.

$\mathrm{LH}(\mathrm{ng} / \mathrm{mL})$

$\mathrm{LH}(\mathrm{ng} / \mathrm{mL})$
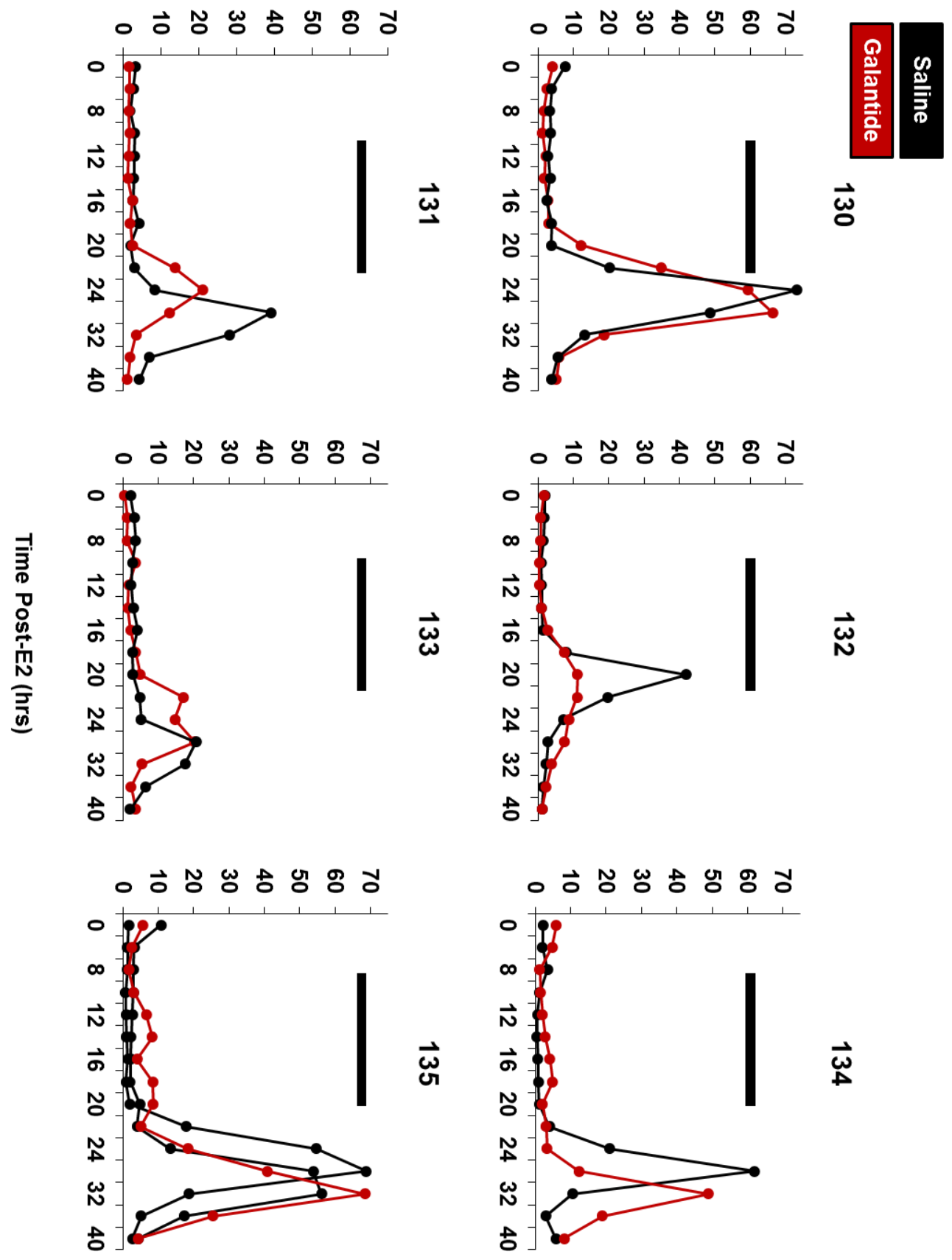

Time Post-E2 (hrs)

$\mathrm{LH}(\mathrm{ng} / \mathrm{mL})$
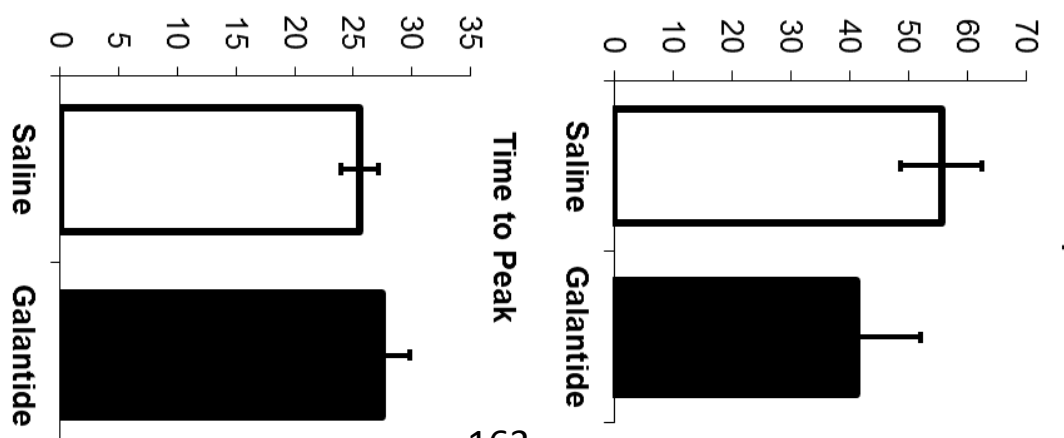

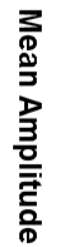


Morphological and Functional Evidence of Sexual Dimorphism in the Retrochiasmatic Area Population of NK3R-containing Neurons in Sheep

\section{CHAPTER V}

\section{GENERAL DISCUSSION}


The preceding chapters describe functional and morphological data collected to test the hypothesis that NK3R activity in the RCh contributes to the control of the LH surge in sheep. In addition, morphological and functional evidence has been provided to test the role of RCh galanin neurons, which represent a subset of the entire RCh NK3R population, in affecting LH secretion.

\section{NKB-NK3R Activity and the LH Surge}

Several lines of evidence described in Chapter 2 led to the hypothesis that NKB-NK3R signaling in the RCh contributes to the LH surge in ewes (1-4). In this report, we observed differences in the patterns of $\mathrm{LH}$ release in response to RCh senktide administration between males and females (Chapter 2). $\mathrm{LH}$ release following administration of senktide in the $\mathrm{RCh}$ was elevated and prolonged in females. This pattern of LH secretion is typical of an LH surge, which lasts approximately 12 hours in sheep (5), and supports the hypothesis that NKB activity within the $\mathrm{RCh}$ is important for the LH surge in females. In contrast, while increased LH release was clearly evident in males, this elevation was transient, lasting only about 2 hours. This led us to propose that the number of NK3R-ir neurons residing within the $\mathrm{RCh}$ is more numerous in females than in males. If this is the case, this population would be expected to be more readily activated and able to respond for a longer period in females. The more prolonged response in females may also be due to a greater number of KNDy neurons in the ARC of females because activation of RCh NK3R-containing cells acts through ARC kisspeptin release to influence LH secretion (3). Regardless, the temporal differences between the sexes in response to senktide provide functional evidence for sexual dimorphism in NKB-NK3R signaling in the RCh of sheep. 


\section{NKB-NK3R Expression in the POA and RCh of Male and Female Sheep}

The discovery of sexual differences in the number of NK3R-containing cells in the POA and RCh supports the possibility that NK3R-containing neurons in these areas may contribute to the LH surge, as discussed above. In Chapter 2, the total number of NK3R-containing cells in the POA was lower in wethers compared to ewes. However, in acutely castrated males, the total number of NK3R-containing cells in in the POA did not differ between sexes after surge-inducing levels of estradiol (Chapter 3). This finding is in agreement with what was observed in prenataltestosterone-treated females (6). One simple explanation for the discrepancy between our two studies is that the prolonged absence of androgens results in decreased NK3R expression in wethers. However, the difference between these two studies may reflect differences in the number of NK3R-ir cells observed in females, rather than differences observed in males, as previously discussed (Chapter 3). Still, the observation that no difference appears in the number of POA NK3R-containing cells between acutely castrated males and females may not be too surprising given two lines of evidence that endogenous NKB may not act in the POA to induce an LH surge. First, administration of a NK3R antagonist into the POA did not alter the timing or amplitude of a LH surge induced with estradiol (2). Second, there was no change in the percent of NK3R cells in the POA that expressed c-Fos during the LH surge compared to the luteal or early follicular phase of the estrous cycle (McCosh et al., unpublished).

The total number of NK3R-containing cells in the RCh was lower in both wethers and acutelycastrated rams compared to females in tissue collected in the presence of surge-inducing levels of estradiol (Chapter 2 and 3). This differs from what is found in prenatal testosterone-treated females 
(6), in which no effect of testosterone treatment on the number of NK3R-containing cells was found in the RCh. This is likely the result of differences in animal models because females born to testosterone-treated mothers still exhibit some aspects of female reproductive function, including a blunted LH surge, for at least two years after birth $(7,8)$. In addition to differences in the number of NK3R-containing neurons, we also observed dramatic sex differences in the quantity of NKB-ir fibers and NKB-containing inputs onto NK3R-ir cells in the RCh (Chapter 2). The presence of NKB-containing fibers in the $\mathrm{RCh}$ is in agreement with previous findings in female sheep (9). However, the origin of these fibers remains unknown. In sheep, nearly all NKBir neurons are located in the ARC $(10,11)$, and the vast majority of these neurons also contain kisspeptin (12). However, these KNDy neurons do not project to the RCh because few, if any, kisspeptin-ir fibers are seen in this region (13). Thus, we concluded that the source of the NKB inputs seen in the RCh could be either the small number of NKB neurons in the ARC that do not co-express kisspeptin (12) or other NKB-producing cells that cannot be detected by immunohistochemistry because the peptide is rapidly transported to terminals.

\section{NKB, Kisspeptin, and NK3R Expression in the ARC of Male and Female Sheep}

The observation that the number of NKB cells in the ARC is higher in young females compared to young males (wethers and acutely-castrated rams) is in agreement with previous results in young and adult intact rams $(10,14)$ and prenatally testosterone-treated females (6). The number of kisspeptin cells in the ARC was also higher in steroid-treated gonadectomized females compared to males in Chapter 3. This is in agreement with earlier reports in adult, gonadally-intact sheep 
(15). In contrast, kisspeptin cell numbers in the ARC are not affected by testosterone treatment in utero because androgenized females do not show reduced levels compared to normal females when tissue is collected during an "artificial follicular phase" (16). The latter observations raised the possibility that the sexual dimorphism seen in gonadally-intact sheep was due to differences in the endogenous hormonal milieu, not the organizational actions of androgens in utero. Tissue in this study was collected during an artificial follicular phase, and because of this, differences in kisspeptin expression cannot be due to differences in endogenous steroid concentrations and thus most likely reflect the organizational actions of androgens. There are two possible explanations for the absence of this sexual dimorphism in prenatally androgenized ewes. The simpler of the two is that more prolonged exposure to androgen in utero may be required. Alternately, post-natal exposure to estradiol may play a role. Postnatal exposure to the ovaries or exogenous estradiol is required for prenatally testosterone-treated females to undergo complete defeminization of the GnRH surge mechanism (17). Thus the possibility exists that during this additional period of "differentiation," postnatal exposure to estrogen, rather than testicular testosterone, within the first few months (or years) of life may influence the KNDy cell population in the ARC. 
Figure 5.1. Schematic representation of connectivity between neurons implicated in the luteinizing hormone surge in sheep.

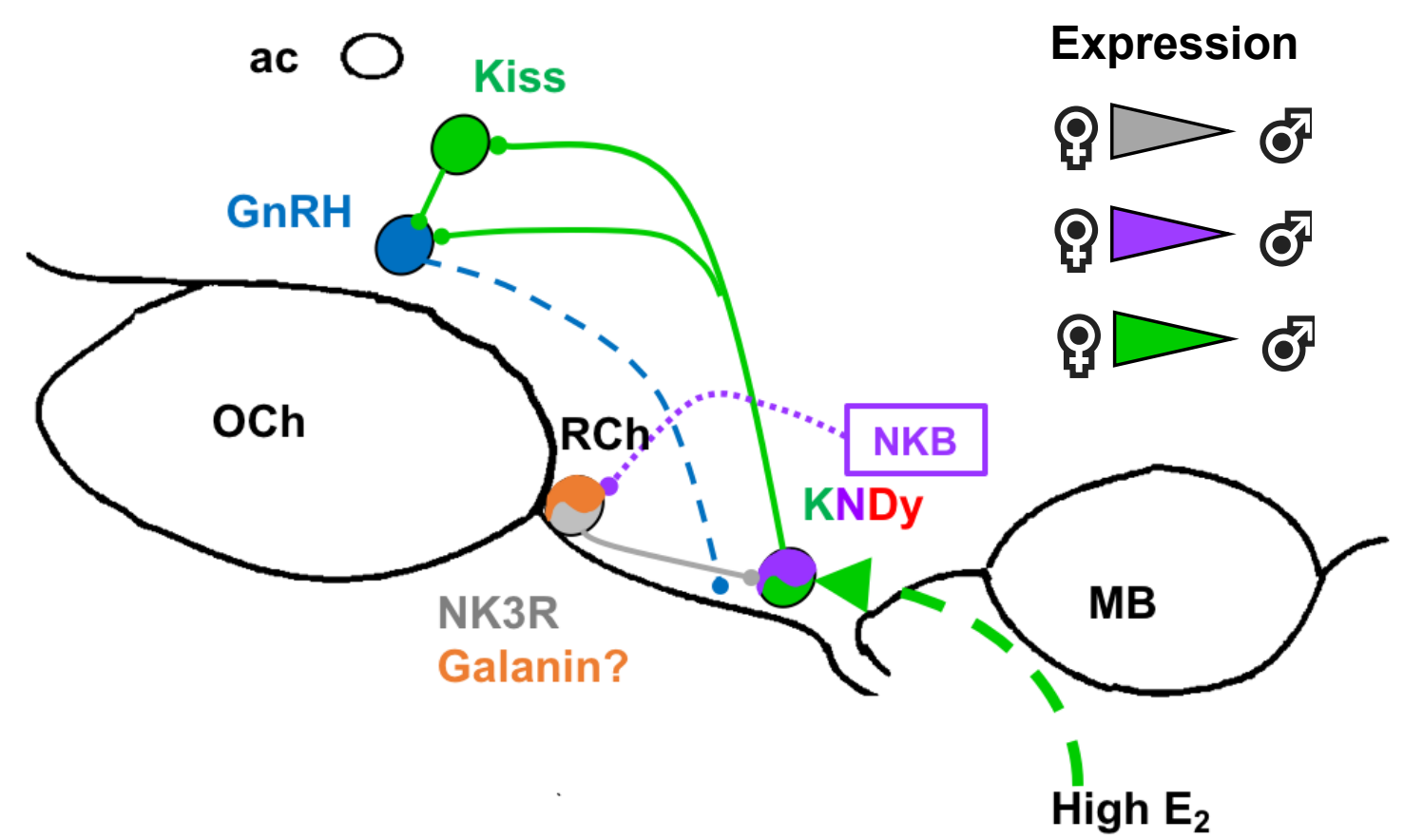

Figure 5.1. NK3R-containing neurons (grey), a percentage of which contain galanin (orange), in the RCh project to KNDy neurons in the ARC. KNDy neurons coexpress kisspeptin (green), NKB (purple), and dynorphin (not illustrated) and innervate kisspeptin (green) and GnRH neurons (blue) neurons in the POA. The source of NKB that activates NK3R-containing neurons in the RCh is currently unknown. Expression of NK3R (grey) and NKB (purple) in the RCh and KNDy cells (purple/green) in the ARC are reduced in males. ac, anterior commissure; inf, infundibular recess; OCh, optic chiasm; MB, mammillary body; $\mathrm{E}_{2}$, estrogen. 
The decreased NKB/NK3R signaling found in males may contribute to the sexual dimorphism in both the response to senktide and the failure of males to produce GnRH/LH surges. The decreased number of NK3R-containing neurons in the RCh of males provides one simple explanation for the attenuated LH response to local administration of senktide observed in Chapter 2. These findings also support the hypothesis that the population of NK3R-containing cells in the RCh is necessary

for full expression of the LH surge in females (2). These cells are thought to increase GnRH/LH secretion during a surge by activating release of kisspeptin from KNDy cells in the ARC (3). Thus, the lower number of KNDy cells in the ARC of males could also contribute to the sexual dimorphism seen in the inability of males to generate an LH surge. However, the ability of senktide to increase $\mathrm{LH}$ secretion in males indicates that the difference in NK3R expression in the RCh and KNDy cell numbers in the ARC cannot account, by themselves, for the lack of an estrogen-induced LH surge. Thus, one can infer that the decrease in NKB input to this region in males likely contributes to the sexual dimorphism in estrogen positive feedback in sheep.

\section{Galanin Expression in the RCh of Sheep}

As previously discussed, the phenotype of NK3R-containing neurons in the RCh has yet to be elucidated. Based on its anatomical distribution in sheep, we hypothesized that one potential neurotransmitter is galanin. Per our initial observations, we found that galanin-ir cells were readily visualized throughout the POA and hypothalamus (Lopez et al., unreported observations). However, no difference was observed in the number of galanin-immunoreactive cells found within the RCh between males and females (Chapter 4). This finding does not agree with the hypothesis 
that sexual dimorphism exists in the population of galanin neurons in the RCh. However, it could be possible that sexual dimorphism exits in neurons upstream of galanin, i.e., NKB as discussed in Chapter 2, and those effects are translated through galanin. Regardless, these results are similar to previous findings that galanin expression throughout the hypothalamus, as a whole, is not sexually dimorphic in sheep $(18,19)$. This is also in contrast to what is observed in rodents, as galanin expression is found to be highly sexually dimorphic in both mice (20) and rats (21). To our knowledge, this is the first report to demonstrate galanin and NK3R colocalization in any species, although no differences were observed in the percentage of galanin/NK3R co-expression between sexes. Furthermore, CT $\beta$-immunoreactive neurons were readily observed in the RCh from females with unilateral injections of CT $\beta$ in the ARC. A portion of these CT $\beta$-positive neurons coexpressed galanin. These findings support galanin as a candidate for the previously unknown phenotype of NK3R-containing cells in the RCh that project to ARC kisspeptin neurons and provide a potential neuroanatomical circuit responsible for inducing a preovulatory LH surge in ewes $(3,4)$. Only about $22 \%$ of the entire NK3R-containing cell population in this region also contain galanin, but it is unknown what percentage of NK3R neurons in this region are dedicated to the LH surge.

\section{Galanin Activity and LH Secretion}

Despite a neuroanatomical basis implicating galanin in stimulating $\mathrm{LH}$ release, central administration of galanin to anestrous or breeding season ewes only had modest effects on LH pulse frequency and amplitude, respectively. Although it was observed that all anestrous animals responded within 1 hour of administration of galanin, sustained LH release was not observed in 
either anestrus or during the breeding season. Additionally, several lines of correlative evidence in sheep (as presented above and elsewhere), and pharmacological data in rodents (22), support a role for galanin in surge-type LH secretion. However, galantide administration did not significantly alter surge secretion in our experiments. Several methodological or theoretical considerations could account for the lack of effect of these drugs in both sets of experiments as discussed in Chapter 4. First, a more effective concentration of galanin or galantide and more localized administration may be necessary to markedly affect surge secretion of LH. The maximum effect we have observed with disruptions of NKB-NK3R signaling in the RCh is a 50\% decrease in amplitude of the surge (2) (Goodman et al., 2018, International Congress of Neuroendocrinology Abstract), so this might be the upper limit of the effects of blocking galanin action in that experiment. Additionally, several redundant systems contribute to the generation of the LH surge (23). Therefore, compensatory pathways could mask any effects caused by altering the effects of galanin. During an estrogen-induced surge, galantide infusion resulted in a minor inhibitory effect on surge amplitude (approximately by 25\%) and in 2 of the 5 animals infused, galantide administration reduced surge amplitude by approximately 50\%. A similar degree of reduction in the amplitude of the LH surge has been shown after icv administration of both a Kiss1r antagonist (24) and NK3R antagonist (2). These findings raise the possibility that the infusion of galantide may be acting on the same populations of neurons that are affected in these previous studies. Additionally, neither the NK3R nor Kiss1r antagonist altered the timing of the surge. As such, the lack of an effect of galantide on this variable is not surprising $(2,24)$.

\section{Conclusions and Future Directions}


In this work, we have demonstrated morphological and functional evidence of sexual dimorphism in NKB-NK3R signaling in the ovine RCh. Senktide administration in the RCh resulted in prolonged, surge-like LH release in female, but not male sheep. This finding is associated with fewer NK3R-positive cells and NKB contacts onto NK3R-containing cells in the RCh, and fewer NKB and kisspeptin cells in the ARC of males. These findings led us to conclude that deficiencies in NKB inputs to the RCh, the response to NKB in the RCh, and in the ability of KNDy neurons to respond to a stimulus from the RCh all contribute to the sex-dependent expression of the $\mathrm{GnRH} / \mathrm{LH}$ surge in sheep. Additionally, we provide evidence for the existence of galanin/NK3R colocalization in the $\mathrm{RCh}$ in females and thus support a role for galanin as a possible candidate for the neurotransmitter in NK3R-containing cells needed for the LH surge in this region. Based on the observation that galanin and $\mathrm{CT} \beta$ colocalize in the RCh, $\mathrm{NKB}$ may stimulate $\mathrm{NK} 3 \mathrm{R}$-containing galanin neurons in the $\mathrm{RCh}$ that project to the ARC to stimulate kisspeptin release from KNDy neurons.

Further work is needed to adequately test this model. One major question that remains is which population of NKB neurons project to the RCh. This question could be tested by injecting retrograde tract tracer Fluorogold into the RCh in ovary-intact ewes. The distribution of these cells can be identified with in situ hybridization and determined to project to the RCh if Fluorogold coexpression is observed. Furthermore, triple-label immunohistochemistry is necessary to test if the population of galanin neurons that co-express CT $\beta$ also contain NK3R. Only a percentage of NK3R neurons contain galanin, and vice-versa; thus, it is difficult to determine whether the galanin neurons that contain CT $\beta$ are those that coexpress NK3R without additional testing. As previously mentioned, testing if the population of galanin neurons that coexpress NK3R also receive NKB 
inputs would be beneficial. The experiment could be performed as previously described (Chapter 2), and the findings from this study could explain why sex differences in galanin cell number are not observed in the RCh. In our functional studies, administration of senktide-containing microimplants in the RCh should be performed in acutely gonadectomized males and females as described in Chapter 2. As discussed in the preceding chapters, LH was not suppressed in wethers to a level that was comparable to females while, in acutely castrated rams, a similar amount of suppression was accomplished. Thus, this model presents a more direct comparison between sexes. Lastly, a more effective concentration of galanin or galantide and/or more localized administration of each peptide may be necessary to markedly affect LH secretion in ewes, as seen in rodents. Additional testing should be performed to more rigorously test this hypothesis before making any definitive statements about the role of galanin in LH secretion in ewes. 


\section{References:}

1. Billings HJ, Connors JM, Altman SN, Hileman SM, Holaskova I, Lehman MN, McManus CJ, Nestor CC, Jacobs BH, Goodman RL. Neurokinin B acts via the neurokinin-3 receptor in the retrochiasmatic area to stimulate luteinizing hormone secretion in sheep. Endocrinology 2010;151(8):3836-3846.

2. Porter KL, Hileman SM, Hardy SL, Nestor CC, Lehman MN, Goodman RL. Neurokinin-3 Receptor Activation in the Retrochiasmatic Area is Essential for the Full Preovulatory LH Surge in Ewes. J. Neuroendocrinol. 2014. doi:10.1111/jne.12180.

3. Grachev P, Porter KL, Coolen LM, McCosh RB, Connors JM, Hileman SM, Lehman MN, Goodman RL. Surge-Like Luteinising Hormone Secretion Induced by Retrochiasmatic Area NK3R Activation is Mediated Primarily by Arcuate Kisspeptin Neurones in the Ewe. J. Neuroendocrinol. 2016;28(6). doi:10.1111/jne.12393.

4. Merkley CM, Porter KL, Coolen LM, Hileman SM, Billings HJ, Drews S, Goodman RL, Lehman MN. KNDy (kisspeptin/neurokinin B/dynorphin) neurons are activated during both pulsatile and surge secretion of LH in the ewe. Endocrinology 2012;153(11):5406-5414.

5. Moenter SM, Caraty A, Karsch FJ. The estradiol-induced surge of gonadotropinreleasing hormone in the Ewe. Endocrinology 1990;127(3):1375-1384.

6. Ahn T, Fergani C, Coolen LM, Padmanabhan V, Lehman MN. Prenatal Testosterone Excess Decreases Neurokinin 3 Receptor Immunoreactivity within the Arcuate Nucleus KNDy Cell Population. J. Neuroendocrinol. 2015;27(2):100-110.

7. Wood RI, Foster DL. Sexual differentiation of reproductive neuroendocrine function in sheep. Rev. Reprod. 1998;3(2):130-140.

8. Birch RA, Padmanabhan V, Foster DL, Unsworth WP, Robinson JE. Prenatal programming of reproductive neuroendocrine function: Fetal androgen exposure produces progressive disruption of reproductive cycles in sheep. Endocrinology 2003;144(4):14261434.

9. Amstalden M, Coolen LM, Hemmerle AM, Billings HJ, Connors JM, Goodman RL, Lehman MN. Neurokinin 3 receptor immunoreactivity in the septal region, preoptic area and hypothalamus of the female sheep: Colocalisation in neurokinin B cells of the arcuate nucleus but not in gonadotrophin-releasing hormone neurones. J. Neuroendocrinol. 2010;22(1):1-12.

10. Goubillon ML, Forsdike RA, Robinson JE, Ciofi P, Caraty A, Herbison AE. Identification of neurokinin B-expressing neurons as an highly estrogen-receptive, sexually dimorphic cell group in the ovine arcuate nucleus. Endocrinology 2000;141(11):4218-4225.

11. Foradori CD, Amstalden M, Goodman RL, Lehman MN. Colocalisation of dynorphin A and neurokinin B immunoreactivity in the arcuate nucleus and median eminence of the sheep. J. Neuroendocrinol. 2006;18(7):534-541.

12. Goodman RL, Lehman MN, Smith JT, Coolen LM, De Oliveira CVR, Jafarzadehshirazi MR, Pereira A, Iqbal J, Caraty A, Ciofi P, Clarke IJ. Kisspeptin neurons in the arcuate nucleus of the ewe express both dynorphin A and neurokinin B. Endocrinology 2007. doi:10.1210/en.2007-0961.

13. Lehman MN, Hileman SM, Goodman RL. Neuroanatomy of the kisspeptin signaling system in mammals: Comparative and developmental aspects. Adv. Exp. Med. Biol. 
2013;784:27-62.

14. Nestor CC, Briscoe AMS, Davis SM, Valent M, Goodman RL, Hileman SM. Evidence of a role for kisspeptin and neurokinin B in puberty of female sheep. Endocrinology 2012;153(6):2756-2765.

15. Cheng G, Coolen LM, Padmanabhan V, Goodman RL, Lehman MN. The kisspeptin/neurokinin B/dynorphin (KNDy) cell population of the arcuate nucleus: Sex differences and effects of prenatal testosterone in sheep. Endocrinology 2010;151(1):301311.

16. Cheng G. Coolen LM. Padmanabhan V. Goodman RL. Lehman M. The kisspeptin/neurokinin B/dynorphin (KNDy) cell population of the arcuate nucleus: sex differences and effects of prenatal. Endocrinology 2010;151(1):301-311.

17. Jackson LM, Mytinger A, Roberts EK, Lee TM, Foster DL, Padmanabhan V, Jansen HT. Developmental programming: Postnatal steroids complete prenatal steroid actions to differentially organize the GnRH surge mechanism and reproductive behavior in female sheep. Endocrinology 2013;154(4):1612-1623.

18. Dufourny L, Schofield N, Skinner DC. Immunoreactive galanin expression in ovine gonadotropin-releasing hormone neurones: No effects of gender or reproductive status. $J$. Neuroendocrinol. 2003;15(11):1062-1069.

19. Tillet Y, Tourlet S, Picard S, Sizaret PY, Caraty A. Morphofunctional interactions between galanin and GnRH-containing neurones in the diencephalon of the ewe. The effect of oestradiol. J. Chem. Neuroanat. 2012;43(1):14-19.

20. Rajendren G, Gibson MJ. Expression of galanin immunoreactivity in gonadotropinreleasing hormone neurons in mice: A confocal microscopic study. Brain Res. 1999. doi:10.1111/j.1525-1594.2011.01363.x.

21. Merchenthaler I, López FJ, Lennard DE, Negro-Vilar A. Sexual differences in the distribution of neurons coexpressing galanin and luteinizing hormone-releasing hormone in the rat brain. Endocrinology 1991. doi:10.1210/endo-129-4-1977.

22. Sahu A, Xu B, Kalra SP. Role of galanin in stimulation of pituitary luteinizing hormone secretion as revealed by a specific receptor antagonist, galantide. Endocrinology 1994. doi:10.1210/endo.134.2.7507825.

23. Goodman RL. Neuroendocrine Control of Gonadotropin Secretion: Comparative Aspects. In: Knobil and Neill's Physiology of Reproduction.; 2015:1537-1574.

24. Smith JT, Li Q, Yap KS, Shahab M, Roseweir AK, Millar RP, Clarke IJ. Kisspeptin is essential for the full preovulatory LH surge and stimulates GnRH release from the isolated ovine median eminence. Endocrinology 2011;152(3):1001-1012.

Justin A. Lopez, Ph.D. 
inlopez@mix.wvu.edu

Morgantown, WV 26505

(704) $989-6845$

https://www.linkedin.com/in/justinlopezphd/

\section{EDUCATION:}

Ph.D. Reproductive Physiology

2018

West Virginia University-Morgantown, WV, USA

Specialization: Reproductive Neuroendocrinology

Dissertation Title: "Morphological and Functional Implications of Sexual Dimorphism in

the Retrochiasmatic Area in Sheep"

Committee: Dr. Robert Goodman, Dr. Stanley Hileman, Dr. Robert Dailey, Dr. Michael

Vernon, Dr. Steven Hardy

M.Sc. Reproductive Physiology

2015

West Virginia University-Morgantown, WV, USA

Specialization: Reproductive Neuroendocrinology

Master's Thesis Title: "The Role of Dynorphin in the Onset of Puberty in Female Lambs"

Committee: Dr. Robert Goodman, Dr. Stanley Hileman, Dr. Robert Dailey

B.A. Biology - Chemistry and Spanish Language Minor

2012

Wingate University-Wingate, NC, USA

Advisor: Dr. Patricia Plant, Dr. Allison Brown

\section{PROFESSIONAL EXPERIENCE:}

Pharmaceutical Technical Investigator/Writer

$2018-2019$

Mylan Pharmaceutical Inc.

Morgantown, WV

\section{Roles:}

- Conduct minor, major, and critical manufacturing and operations related investigations to arrive at root cause, determine product impact, and assess trending

- Identify and implement appropriate and effective corrective/preventative actions (CAPA)

- Collaborate with the Learning and Development department to implement investigation-related training

- Conduct meetings with Quality Unit and other departments (i.e., subject matter experts) to discuss investigative information, assistance with investigative activities, CAPA evaluation, trend analysis, and priority alignment

\section{Accomplishments:}

- Closed 31 investigations over the last 6 months, greatly surpassing expectations for effectively drafting and routing investigations for closure 
- As a part of the Cleaning Validation (CVAL) Investigations team, assisted/closed a total 243 investigations, greatly reducing the investigation burden

- Established a cooperative relationship through the investigation peer-review system between author and Quality Investigations reviewer

- Gained access and effectively used on-site data systems (i.e., DCM, CARA, LIMS, SAP, TrackWise) with minimal assistance in order to initiate, author, and complete manufacturing investigations

- Demonstrated an ability to learn rapidly and adapt quickly to changing situations while in FDA-warranted remediation

- Planned and facilitated high-importance meetings to ensure project alignment on highpriority investigations

Graduate Research Assistant

Department of Physiology, Pharmacology, and Neuroscience

$2013-2018$

West Virginia University-Morgantown, WV, USA

Roles:

- Planned and developed numerous experiments that fulfilled requirements of Principal Investigator's NIH grant

- Independently conducted research related to sexual dimorphism of the hypothalamic retrochiasmatic area

- Investigated if sex differences exist in the expression of neurokinin 3 receptor and neuropeptides neurokinin B and kisspeptin

- Characterized the expression and distribution of neuropeptide galanin throughout the ovine preoptic area and hypothalamus in males and females

- Conducted research related to the involvement of the neuropeptides kisspeptin and dynorphin in the onset of puberty in females

- Performed numerous advanced scientific techniques

- Presented findings in professional settings, such as departmental seminars and both national and international meetings

\section{Accomplishments:}

- Instructed, educated, and trained numerous undergraduate students and mentored incoming graduate students on procedures related to immunohistochemistry and microscopy of hypothalamic tissue sections, blood collection, neurosurgery procedures, scientific writing, and comprehending complex signaling pathways and drug mechanisms

- Published 5 peer-reviewed manuscripts in journals ranging from The Journal of Neuroendocrinology to The Endocrine Society

- Successful funding of pre-doctoral fellowship: Diversity Supplement Award funded by Eunice Kennedy Shriver National Institute of Child Health and Human Development, $\mathrm{NIH}$ grant R01 HD039916

\section{Research Assistant}

$2012-2013$

Department of Veterinary and Animal Science

University of Massachusetts, Amherst-Amherst, MA, USA

Advisor: Dr. Sandra Petersen

\section{Roles:}


- Conducted independent research related to the expression of signaling molecule neudesin in the developing and adult preoptic area and hypothalamus

- Investigated the role of neudesin in the induction of pre-ovulatory luteinizing hormone release in females

- Participated in animal care, blood sampling, brain collection, and whole-body perfusion in rodents

- Performed numerous advanced scientific techniques, such as PCR, immunohistochemistry, and in situ hybridization

- Presented findings in professional settings, such as departmental seminars and both national meetings

\section{Accomplishments:}

- Published 2 peer-reviewed manuscripts in journals ranging from The Journal of Neuroendocrinology to Frontiers of Neuroendocrinology

- Successful completion of the Summer Program for Undergraduate Research (SPUR) and The Post-Baccalaureate Research Education Program (PREP)

\section{SKILLS:}

- Communicate therapeutic drug mechanisms

- Communicate complex signaling pathways

- Communicate complex technical/mechanical pathways

- Academic institution presentations

- National/International conference presentations

- Intensive data analysis

- Advanced scientific writing

- Plan and design research projects

- Leadership and mentor/ instructor and trainer

- Independent and team-based research roles

- Advanced scientific techniques

- $\quad \mathrm{NIH}$ grant writing and manuscript preparation

- Technical writing experience

- Advanced knowledge of Microsoft Office Suite

- Detail-oriented scientist

- Detail-oriented pharmaceutical investigator

- Operations/manufacturing pharmaceutical industry knowledge 


\section{PROFESSIONAL AFFILIATIONS:}

- Pan American Neuroendocrine Society (PANS), 2018 - present

- The Endocrine Society (ENDO), 2014 - present

- Society for Neuroscience (SfN), 2014 - present

\section{PUBLICATIONS:}

Peer reviewed manuscripts and manuscripts in preparation ( ${ }^{*}$ indicates primary author):

1. Lopez JA*, McCosh RB, Bedenbaugh MN, Lindo AN, Bowdridge EC, Hileman SM, Goodman RL. Morphological and Functional Evidence of Sexual Dimorphism in the Retrochiasmatic Area Population of NK3R-containing Neurons in Sheep. Endocrinology (Submitted September 2018).

2. Bedenbaugh MN, McCosh RB, Lopez JA, Rainey CA, Lindo AN, Gooman RL, Hileman SM. Potential Importance of the NKB/NK3R System in the Preoptic Area for Puberty in Female Sheep. Journal of Neuroendocrinology (Submitted February 2018).

3. Bedenbaugh MN, McCosh RB, Lopez JA, Connors JM, Goodman RL, Hileman SM. Neuroanatomical Relationship of nNOS to GnRH and Kisspeptin in Adult Female Sheep and Primates. Neuroendocrinology (Submitted February 2018).

4. Bedenbaugh MN, O'Connell RC, Lopez JA, McCosh RB, Goodman RL, Hileman SM. Kisspeptin, $\mathrm{GnRH}$, and ER $\alpha$ colocalise with nNOS neurones in prepubertal female sheep. Journal of Neuroendocrinology (Submitted September 2017).

5. McCosh RB, Szeligo BM, Bedenbaugh MN, Lopez JA, Hardy SL, Hileman SM, Lehman MN, Goodman RL. Evidence that endogenous somatostatin inhibits episodic, but not surge, secretion of LH in female sheep. Endocrinology. 2017 Jun 1;158(6):1827-37.

6. Lopez JA* , Bedenbaugh MN, McCosh RB, Weems PW, Meadows LJ, Wisman B, Coolen LM, Goodman RL, Hileman SM. Does Dynorphin Play a Role in the Onset of Puberty in Female Sheep? Journal of Neuroendocrinology. 2016 Dec 1;28(12).

7. Petersen SL, Intlekofer KA, Moura-Conlon PJ, Brewer DN, del Pino Sans J, Lopez JA. Nonclassical progesterone signalling molecules in the nervous system. J Neuroendocrinol 2013; 25:991-1001.

8. Petersen SL, Krishnan S, Aggison LK, Intlekofer K, Moura-Conlon PJ, Brewer DN, del Pino Sans J, Lopez JA. Sexual differentiation of the gonadotropin surge release mechanism: a new role for the canonical NfkB signaling pathway. Front Neuroendocrinol 2012; 33:36-44.

\section{RELEVANT PROFESSIONAL DEVELOPMENT:}

- International Congress of Neuroscience, 2018 (poster presentation)

- Van Liere Research Day, 2018 (poster presentation)

- Davis College Graduate Student Research and Creative Scholarship Day, 2016 (poster presentation)

- Invited seminar speaker, Wingate University, 2015 (45-minute oral presentation)

- Society for Neuroscience Annual Meeting, 2015 (poster presentation)

- Endocrine Society Annual Meeting, 2015 (poster presentation)

- Betschart Symposium, 2014 (15-minute oral presentation) 
- Annual Biomedical Research Conference for Minority Students, 2013 (poster presentation)

\section{CONFERENCE ABSTRACTS:}

1. Lopez JA*, McCosh RB, Bedenbaugh MN, Lindo AN, Bowdridge EC, Goodman RL, Hileman SM. 2018 Evidence for morphological sexual dimorphism in the Retrochiasmatic area population of NK3R-containing neurons. Society for Neuroscience (San Diego, CA).

2. Goodman RL, Lopez JA, Bedenbaugh MN, Connors JM, Hardy SL, Hileman SM, Coolen LM, Lehman MN. 2018 Evidence that the LH surge in ewes involves both NKBdependent and NKB-independent actions of Kisspeptin. Society for Neuroscience (San Diego, $C A$ ).

3. Lopez JA*, McCosh RB, Bedenbaugh MB, Lindo AN, Connors JM, Hileman SM, Goodman RL. 2018 The Response to Senktide Administration in the Retrochiasmatic Area $(\mathrm{RCh})$ is Sexually Dimorphic in Lambs. International Congress of Neuroendocrinology (Toronto, Canada).

4. Goodman RL, Coolen L, McCosh RB, Lopez JA, Bedenbaugh MB, Connors JM, Hardy SL, Hileman SL, Lehman M. 2018 Lesions of NK3R-containing Neurons in the Retrochiasmatic Area (RCh) Blunts the LH Surge in Ewes. International Congress of Neuroendocrinology (Toronto, Canada).

5. Bedenbaugh MN, McCosh RB, Lopez JA, Connors JM, Hardy SL, Goodman RL, Hileman SL. 2018 The Neuroanatomical Relationship of nNOS to Kisspeptin and GnRH in Adult Female Sheep and Primates. International Congress of Neuroendocrinology (Toronto, Canada).

6. Bedendbaugh MN, Rainey CA, McCosh RB, Lopez JA, Goodman RL, Hileman SH. 2017 Examiniation of Age-related Changes in NK3R Expression and Colocalization of KOR with GnRH Neurons in the Hypothalamus of Female Sheep. Annual Society for Neuroscience Meeting (Washington D.C.).

7. McCosh RB, Szeligo BM, Bedendbaugh MN, Lopez JA, Hardy SL, Hileman SH, Connors JM, Goodman RL. 2017 Somatostatin Receptor 2 Antagonist, CYN154806, Stimulates Steroid Independent Episodic LH Secretion in Ewes. Annual meeting of the Endocrine Society (Orlando, FL).

8. Bedendbaugh MN, O'Connell RC, Lopez JA, McCosh RB, Hileman SH, Goodman RL. 2017 Kisspeptin and GnRH Neurons in Prepubertal Female Sheep Express Neuronal Nitric Oxide Synthase. Annual meeting of the Endocrine Society (Orlando, FL).

9. McCosh RB, Bedenbaugh MN, Lopez JA, Hileman SH, Grachev P, Valent M, Goodman RL. 2016 Blockade of somatostatin receptor 2 stimulates episodic LH secretion, but not surge LH secretion, in ewes. Annual Society for Neuroscience Meeting (San Diego, CA).

10. Bedendbaugh MN, Rainey CA, McCosh RB, Lopez JA, Goodman RL, Hileman SH. 2016 Neurokinin B, but not dynorphin, acts in the arcuate nucleus of prepubertal female sheep to control LH secretion. Annual Society for Neuroscience Meeting (San Diego, CA).

11. Bedendbaugh MN, Lopez JA, McCosh RB, Goodman RL, Hileman SH. 2016 Characterization of Neuronal Nitric Oxide Synthase Neurons in the Hypothalamus of Prepubertal Sheep. Annual meeting of the Endocrine Society (Boston, MA).

12. Lopez JA*, McCosh RB, Nesselrod GL, Bedenbaugh MN, Hardy SL, Goodman RL, and Hileman SM. 2015 Evidence that alteritions in plays an important role in ovine sexual maturation. Annual meeting of the Endocrine Society (San Diego, CA). 
13. Lopez JA*, Wisman BR, Meadows LJ, McCosh RB, Goodman RL, and Hileman SM. 2014 Is dynorphin involved in the prepubertal suppression of LH secretion by estradiol in female sheep?. Annual meeting of the Society for Neuroscience (Washington D.C.).

14. Grachev P, McCosh RB, Lopez JA*, Meadows LJ, Nesselrod GL, Valent M, Hardy SL, Connors JM, Hileman SM, and Goodman RL. 2014 Surge-like LH secretion induced by retrochiasmatic area NK3R activation is mediated by kisspeptin/GPR54 signaling in ovaryintact ewes. International Congress of Neuroendocrinology (Hilton Sydney, Australia).

15. Lopez JA*, del Pino Sans J, Petersen SL. 2012 Neudesin expression in the developing and adult rats preoptic area and hypothalamus. Annual Biomedical Research Conference for Minority Students (San Francisco, CA).

\section{AWARDS AND SCHOLARSHIPS:}

- 2015 - 2018. Recipient of Diversity Supplement Award funded by Eunice Kennedy Shriver National Institute of Child Health and Human Development, NIH grant R01 HD039916

- 2014. Recipient of Early Career Forum Travel Award for the Society of Endocrinology Meetings 2014, San Diego, CA, USA.

- 2008 - 2012. Trustee Scholarship funded by Wingate University, Wingate University, Wingate, NC, USA

- 2008 - 2012. Legacy Scholarship funded by Wingate University, Wingate University, Wingate, NC, USA 